BNL 52551

Formal Report

\title{
RADIOLOGICAL ENVIRONMENTAL MONITORING REPORT FOR BROOKHAVEN NATIONAL LABORATORY 1967-1970
}

by

C.B. Meinhold and A.P. Hull

October 1998

DISTRIBUTION OF THIS DOCUMENT IS UUU HITED

MASTER

Brookhaven National Laboratory

Brookhaven Science Associates

Upton, New York 11973-5000

Work performed under Contract No. DE-AC02-98CH10886 with the United States Department of Energy. 



\section{DISCLAIMER}

Portions of this document may be illegible in electronic image products. Images are produced from the best available original document. 


\section{CONTENTS}

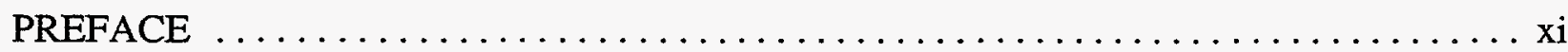

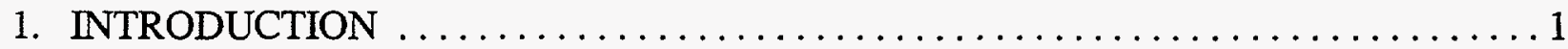

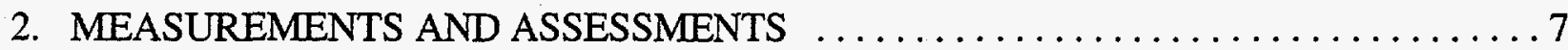

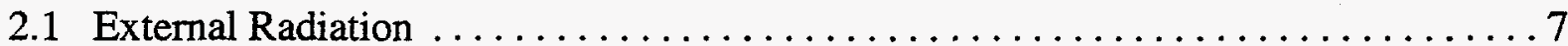

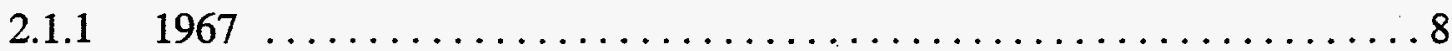

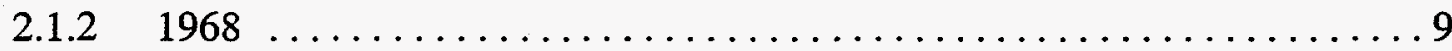

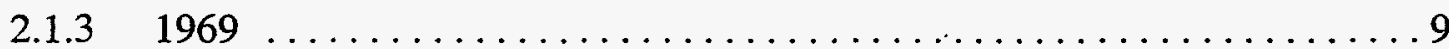

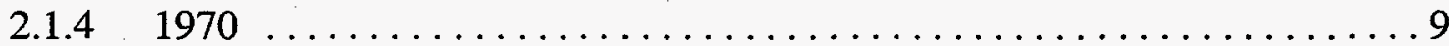

2.2 Environmental Airborne Particulate Radionuclides $\ldots \ldots \ldots \ldots \ldots \ldots \ldots \ldots$

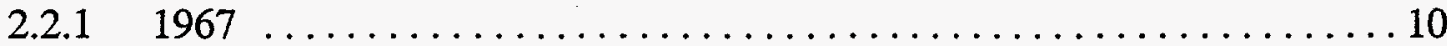

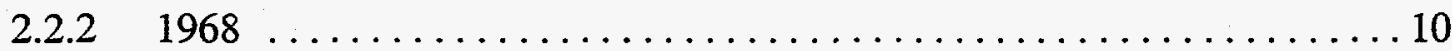

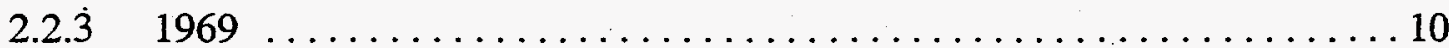

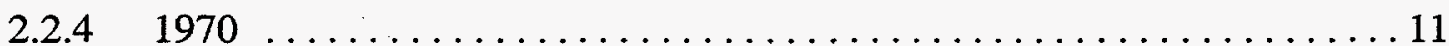

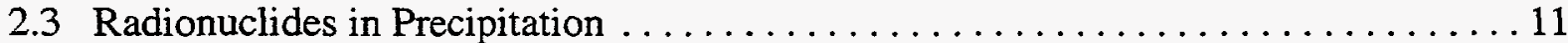

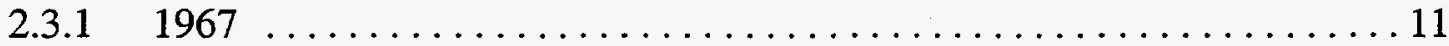

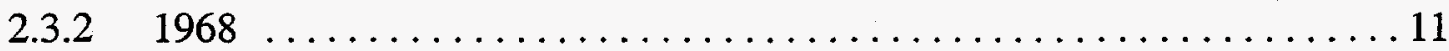

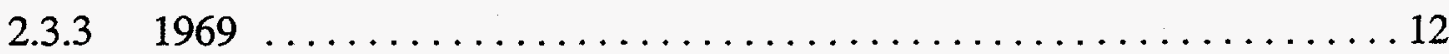

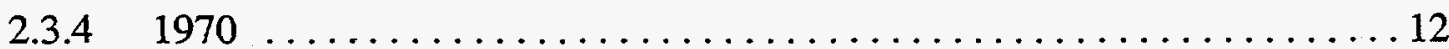

3. CORRELATION OF BGRR-HFBR STACK RELEASES AND

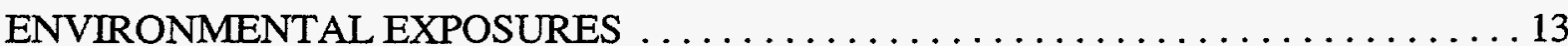

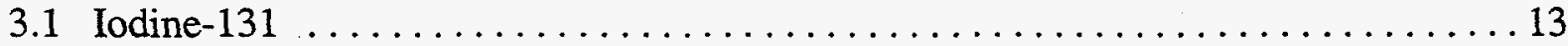

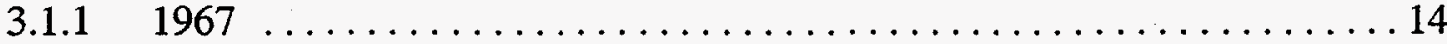

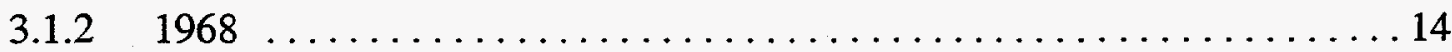

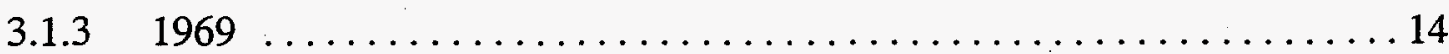

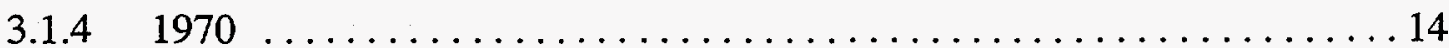

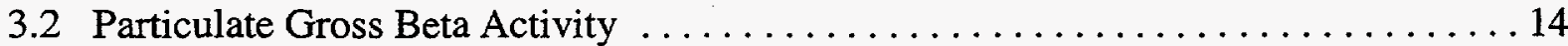

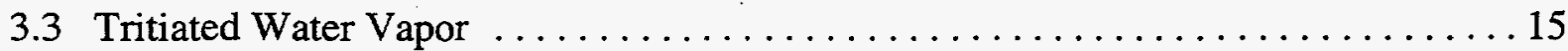

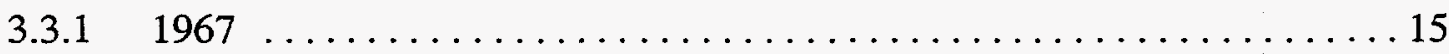

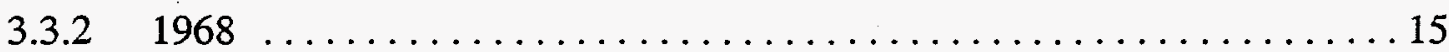

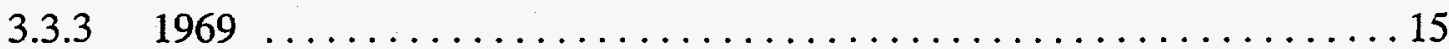

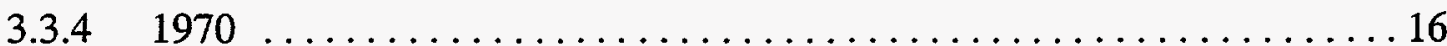


4. RADIOACTIVITY IN LIQUID EFFLUENTS $\ldots \ldots \ldots \ldots \ldots \ldots \ldots \ldots \ldots \ldots$

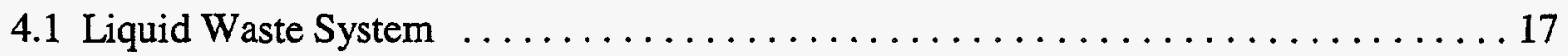

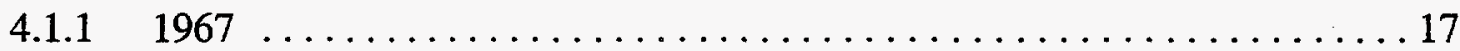

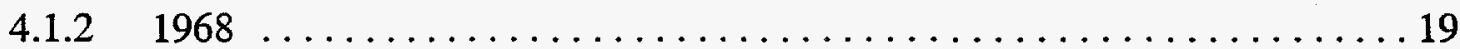

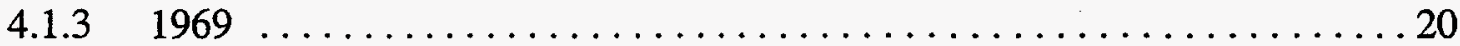

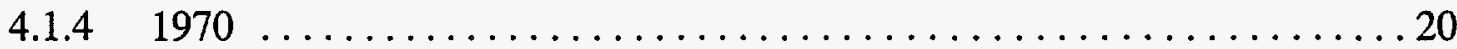

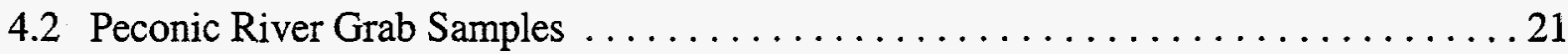

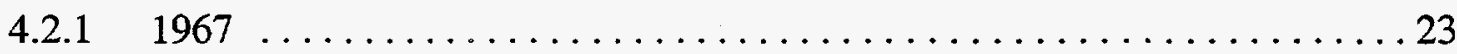

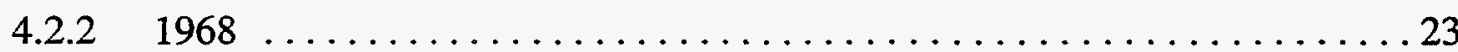

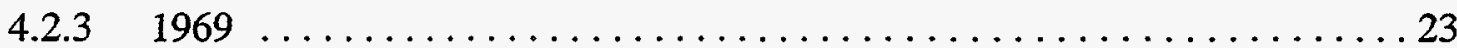

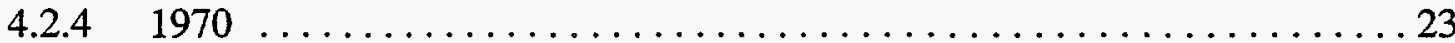

4.3 River Bottom, Vegetation, and Fauna Sampling . . . . . . . . . . . . 24

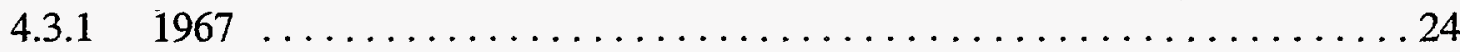

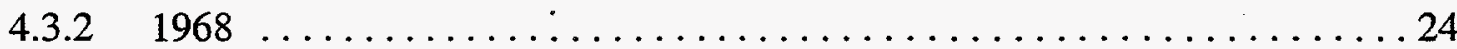

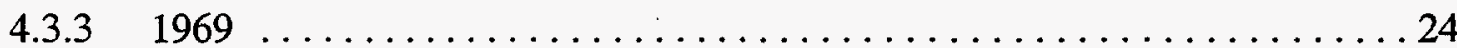

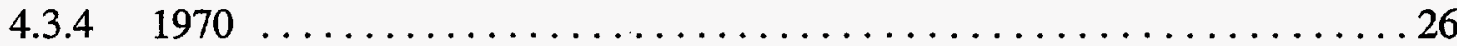

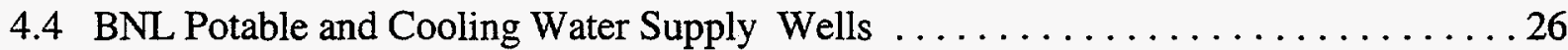

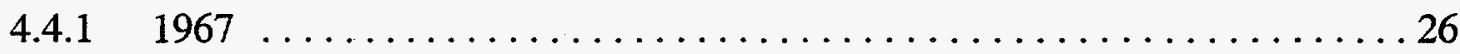

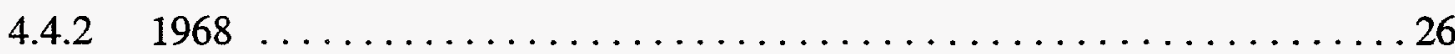

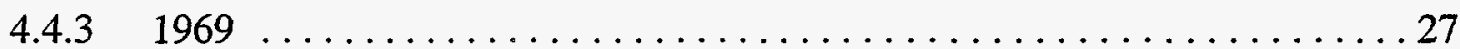

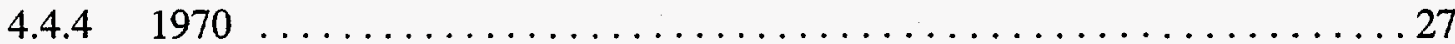

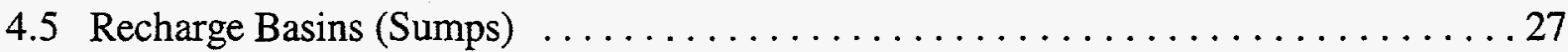

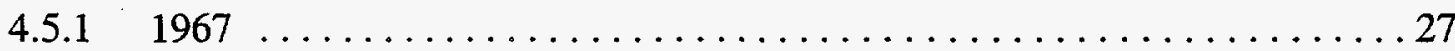

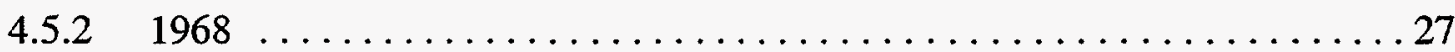

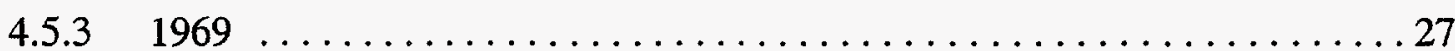

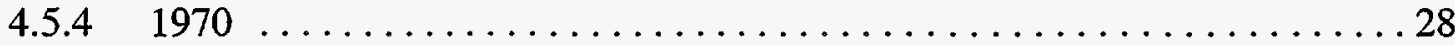

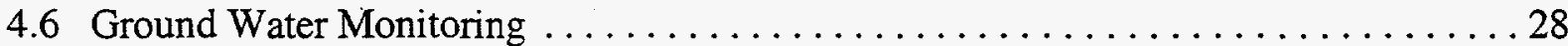

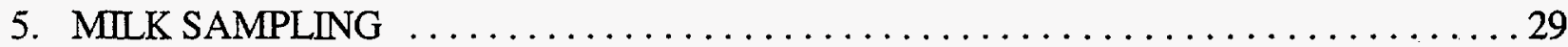

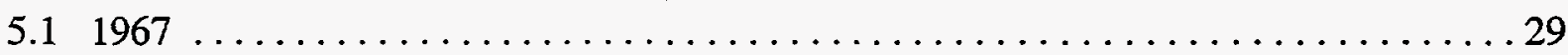

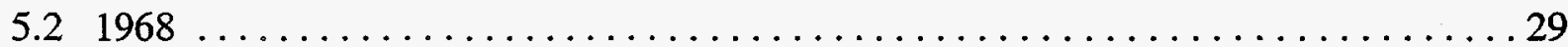

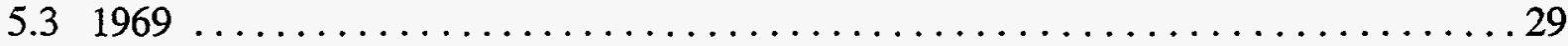

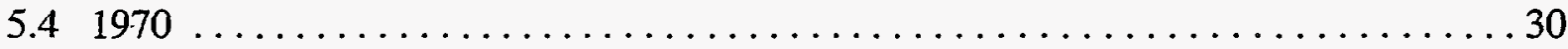




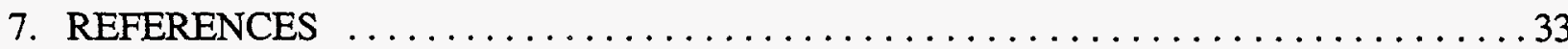

\section{LIST OF FIGURES}

Figure 1 Central Suffolk County, showing the area around Brookhaven

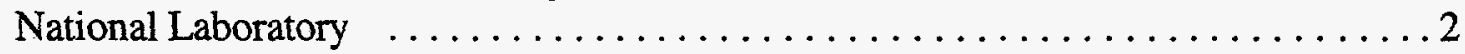

Figure 2 Principal Laboratory Sources of and Monitoring Stations for Environmental Radiation $\ldots \ldots \ldots \ldots \ldots \ldots \ldots \ldots \ldots \ldots \ldots \ldots \ldots \ldots$

Figure 3 Annual Wind Distribution, $1960-73 \ldots \ldots \ldots \ldots \ldots \ldots \ldots \ldots$

Figure 4 Schematic Groundwater Flow Lines, Brookhaven National Laboratory . . . . . . . 5

Figure 5 Brookhaven National Laboratory Sanitary Waste System $\ldots \ldots \ldots \ldots \ldots \ldots$

Figure 6 Peconic River Sampling Locations $\ldots \ldots \ldots \ldots \ldots \ldots \ldots \ldots \ldots \ldots \ldots \ldots \ldots \ldots \ldots$

Figure 7 Potable and Cooling Water Supply Wells and Recharge Basins $\ldots \ldots \ldots \ldots 25$

\section{LIST OF TABLES}

Table 1. Radiation Protection Guides Reflected in this Report $\ldots \ldots \ldots \ldots \ldots \ldots$

\section{Appendix A. 1967 Tables}

Table A-1 1967 Background and Source Radiation Levels at the Laboratory

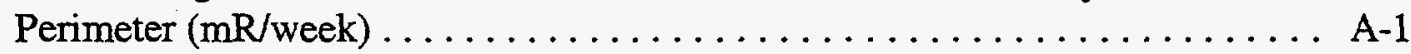

Table A-2 1967 Monthly Average Gross Beta Concentrations, Air Particulate Filters $\left(\mathrm{pCi} / \mathrm{m}^{3}\right)$

Table A-3 1967 Monthly Average Gross Beta Concentrations and Total Gross Beta Activity in Precipitation A-3

Table A-4 1967 BGRR-HFBR Stack Emission $\ldots \ldots \ldots \ldots \ldots \ldots \ldots \ldots \ldots$ A-4

Table A-5 1967 Imhoff/Clarifier Tank. Flow, Gross Beta, Tritiated Water, ${ }^{90} \mathrm{Sr}$, and ${ }^{137} \mathrm{Cs}$ Amounts and Concentrations .................... A 5 
Table A-6 1967 Chlorinating Plant. Flow, Gross Beta, Tritiated Water, ${ }^{90} \mathrm{Sr}$, and

${ }^{137} \mathrm{Cs}$ Amounts and Concentrations . . . . . . . . . . . . . . A-6

Table A-7 1967 "M" (Former Perimeter). Flow, Gross Beta, Tritiated Water, ${ }^{90} \mathrm{Sr}$, and ${ }^{137} \mathrm{Cs}$ Amounts and Concentrations .................... A-7

Table A-8 1967 "Q" (Current Perimeter). Flow, Gross Beta, Tritiated Water, ${ }^{90} \mathrm{Sr}$, and ${ }^{137} \mathrm{Cs}$ Amounts and Concentrations .................. A -8

Table A-9 1967 Monthly Downstream and Control Location Water Grab Samples.

Gross Beta and Tritiated Water Concentrations . . . . . . . . . . . . A-9

Table A-10 1967 Gross Beta and Tritiated Water Concentrations in Potable and Cooling

Water Supply Wells ... . . . . . . . . . . . . . . . . . . A-10

Appendix B. 1968 Tables

Table B-1 1968 Background and Source Radiation Levels at the Laboratory

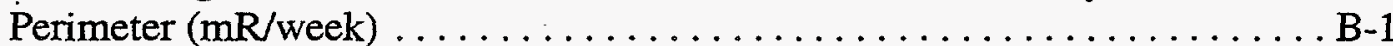

Table B-2 1968 Monthly Average Gross Beta Concentrations, Air Particulate Filters $\left(\mathrm{pCi} / \mathrm{m}^{3}\right)$

Table B-3 1968 Monthly Average Gross Beta Concentrations and Total Gross Beta Activity in Precipitation $\ldots \ldots \ldots \ldots \ldots \ldots \ldots \ldots \ldots \ldots \ldots \ldots \ldots \ldots \ldots$

Table B-4 1968 BGRR-HFBR Stack Emission $\ldots \ldots \ldots \ldots \ldots \ldots \ldots \ldots \ldots . . . . . .$.

Table B-5 1968 Clarifier. Flow, Gross Beta, Tritiated Water, ${ }^{90} \mathrm{Sr}$, and ${ }^{137} \mathrm{Cs}$ Amounts and Concentrations . . . . . . . . . . . . . . . . . . . . . . B -5

Table B-6 1968 Chlorinating Plant. Flow, Gross Beta, Tritiated Water, ${ }^{90} \mathrm{Sr}$, and ${ }^{137} \mathrm{Cs}$ Amounts and Concentrations ................ 6

Table B-7 1968 "M" (Former Perimeter). Flow, Gross Beta, Tritiated Water, ${ }^{90} \mathrm{Sr}$, and ${ }^{137} \mathrm{Cs}$ Amounts and Concentrations ..................

Table B-8 1968 “Q” (Current Perimeter). Flow, Gross Beta, Tritiated Water, ${ }^{90} \mathrm{Sr}$, and ${ }^{137} \mathrm{Cs}$ Amounts and Concentrations . . . . . . . . . . . . . . . B-8

Table B-9 1968 Monthly Downstream and Control Location Water Grab Samples. Gross Beta and Tritiated Water . . . . . . . . . . . . . . . B-9

Table B-10 1968 Bottom Sediment Sample Concentrations . . . . . . . . . . . . . . B-10 
Table B-11 1968 Concentrations of Gamma-emitting Nuclides in Animals and Vegetation Obtained from the Peconic River ................. B-11

Table B-12 1968 Gross Beta and Tritiated Water Concentrations in Potable and Cooling Water Supply Wells $\ldots \ldots \ldots \ldots \ldots \ldots \ldots \ldots \ldots \ldots \ldots \ldots \ldots \ldots \ldots$

Table B-13 1968 Monthly On-Site Sump Samples. Gross Beta and Tritiated Water Concentrations . . . . . . . . . . . . . . . .

Table B-14 Concentrations in 1968 Milk Samples from Off-site Dairies . . . . . . . . B-14

Table B-15 Concentrations in 1968 Vegetation Sampled from Off-site Farms . . . . . . B-15

Table B-16 Concentrations in 1968 Soil Sampled from Off-site Farms . . . . . . . . . . B-16

\section{Appendix C. 1969 Tables}

Table C-1 1969 Background and Source Radiation Levels at the Laboratory Perimeter

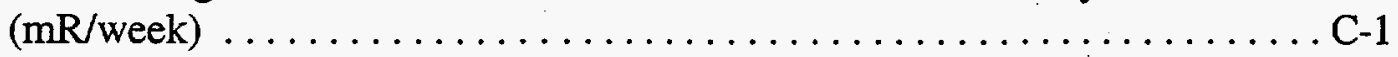

Table C-2 1969 Monthly Average Gross Beta Concentrations, Air Particulate Filters $\left(\mathrm{pCi} / \mathrm{m}^{3}\right)$

Table C-3 1969 Monthly Average Gross Beta Concentrations and Total Gross Beta Activity in Precipitation ...........................

Table C-4 1969 BGRR-HFBR Stack Emission $\ldots \ldots \ldots \ldots \ldots \ldots \ldots \ldots \ldots \ldots$ C-4

Table C-5 1969 Clarifier. Flow, Gross Beta, Tritiated Water, ${ }^{90} \mathrm{Sr}$, and ${ }^{137} \mathrm{Cs}$

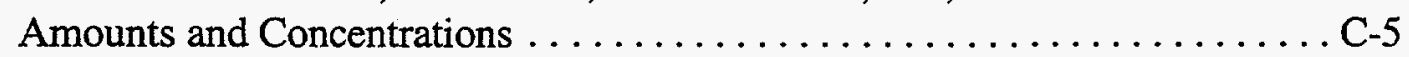

Table C-6 1969 Chlorinating Plant. Flow, Gross Beta, Tritiated Water, ${ }^{90} \mathrm{Sr}$, and ${ }^{137} \mathrm{Cs}$ Amounts and Concentrations . . . . . . . . . . . . . . . . 6

Table C-7 1969 "M" (Former Perimeter). Flow, Gross Beta, Tritiated Water, ${ }^{90} \mathrm{Sr}$, and ${ }^{137} \mathrm{Cs}$ Amounts and Concentrations .................... 7

Table C-8 1969 "Q" (Current Perimeter). Flow, Gross Beta, Tritiated Water, ${ }^{90} \mathrm{Sr}$, and ${ }^{137} \mathrm{Cs}$ Amounts and Concentrations . . . . . . . . . . . .

Table C-9 1969 Monthly Downstream and Control Location Water Grab Samples. Gross Beta and Tritiated Water $\ldots \ldots \ldots \ldots \ldots \ldots \ldots \ldots \ldots \ldots \ldots \ldots \ldots$

Table C-10 1969 Bottom Sediment Sample Concentrations $\ldots \ldots \ldots \ldots \ldots \ldots \ldots$ C-10 
Table C-11 1969 Concentrations of Garnma-emitting Nuclides in Animals and Vegetation Obtained from the Peconic River

Table C-12 1969 Gross Beta and Tritiated Water Concentrations in Potable and

Cooling Water Supply Wells

Table C-13 1969 Monthly On-Site Sump Samples. Gross Beta and Tritiated

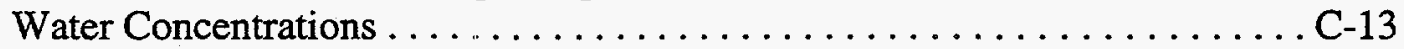

Table C-14 Concentrations in 1969 Milk Samples from Off-site Dairies . . . . . . . . C-14

Table C-15 Concentrations in 1969 Vegetation Sampled from Off-site Farms . . . . . . C-15

Table C-16 Concentrations in 1969 Soil Sampled from Off-site Farms . . . . . . . . . . . C-16

Appendix D. 1970 Tables

Table D-1 1970 Background and Source Radiation Levels at the Laboratory

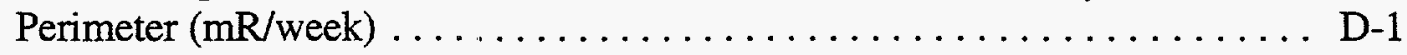

Table D-2 1970 Monthly Average Gross Beta-emitting Isotope Concentrations, Air Particulate Filters $\left(\mathrm{pCi} / \mathrm{m}^{3}\right) \quad \ldots \ldots \ldots \ldots \ldots \ldots \ldots \ldots \ldots \ldots \ldots \ldots \ldots \ldots \ldots$

Table D-3 1970 Monthly Average Gross Beta Concentrations and Total Gross Beta

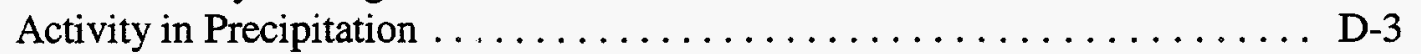

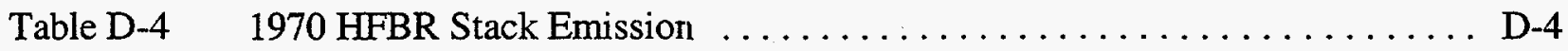

Table D-5 1970 Clarifier. Flow, Gross Beta, Tritiated Water, ${ }^{90} \mathrm{Sr}$, and ${ }^{137} \mathrm{Cs}$ Amounts

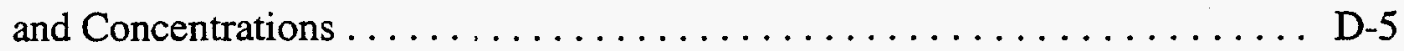

Table D-6 1970 Chlorinating Plant. Flow, Gross Beta, Tritiated Water, ${ }^{90} \mathrm{Sr}$, and ${ }^{137} \mathrm{Cs}$ Amounts and Concentrations .....................

Table D-7 1970 "M" (Former Perimeter). Flow, Gross Beta, Tritiated Water, ${ }^{90} \mathrm{Sr}$, and ${ }^{137} \mathrm{Cs}$ Amounts and Concentrations ................... D-7

Table D-8 1970 "Q" (Current Perimeter). Flow, Gross Beta, Tritiated Water, ${ }^{90} \mathrm{Sr}$, and ${ }^{137} \mathrm{Cs}$ Amounts and Concentrations ................

Table D-9 1970 Monthly Downstream and Control Water Grab Samples.

Gross Beta and Tritiated Water ...................... D

Table D-10 1970 Bottom Sediment Sample Concentrations $\ldots \ldots \ldots \ldots \ldots \ldots \ldots$ D-10 
Table D-11 1970 Concentrations of Gamma-emitting Nuclides in Vegetation Obtained from the Peconic River ..................... D-11

Table D-12 1970 Gross Beta and Tritiated Water Concentrations in Potable and

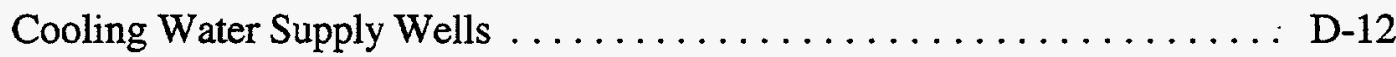

Table D-13 1970 Monthly On-Site Sump Samples. Gross Beta and Tritiated Water Concentrations .............................

Table D-14 Concentrations in 1970 Milk Samples from Off-site Dairies . . . . . . . . D-14

Table D-15 Concentrations in 1970 Vegetation Sampled from Off-site Farms ....... D-15

Table D-16 Concentrations in 1970 Soil Sampled from Off-site Farms . . . . . . . . . D-16 


\section{PREFACE}

Brookhaven National Laboratory (BNL) was established in 1947 on the former Army Camp Upton site located in central Long Island, New York. From the very beginning, BNL has monitored the environment on and around the Laboratory site to assess the effects of its operations on the environment.

Early monitoring focused on radiation, and data were reported in various internal documents and in publications presented at scientific meetings. They were also summarized in the Laboratory's annual progress reports, which were submitted to the U.S. Atomic Energy Commission (AEC). The AEC was a predecessor to the U.S. Department of Energy, which funds BNL today.

In 1960, the AEC instituted a program for public reporting of radioactivity data collected in the vicinity of major AEC installations. As part of that program, BNL began issuing to major Long Island newspapers reports on radiation levels measured in the environment.

In 1963, BNL pioneered the development of an annual environmental monitoring report. The first report was for calendar year 1962. ${ }^{1}$ Reports were also prepared for calendar years $1963,{ }^{2} 1964,{ }^{3} 1965,{ }^{4}$ and $1966 .{ }^{5}$

Because these reports were not required by the AEC, they were completed when time and staff resources were available. As a result, BNL did not compile annual reports for the years 1967 through 1970, although environmental monitoring continued as usual.

In 1971, for the first time, annual site environmental reports became a contractual obligation for all AEC facilities. Thus, BNL has prepared a site monitoring report every year from 1971 onward.

This document summarizes the environmental data collected for the years 1967, 1968, 1969, and 1970. Thus, it fills a gap in the series of BNL annual environmental reports beginning in 1962.

The data in this document reflect measurements for those four years of concentrations and/or amounts of airborne radioactivity, radioactivity in streams and ground water, and external radiation levels in the vicinity of BNL. Also included are estimates, made at that time, of BNL's contribution to radioactivity in the environment.

Information in this document comes primarily from internal monthly reports from the Environmental Monitoring Group Leader to the Health Physics Division head. ${ }^{6}$ Additional data were obtained from monthly Health Physics and Safety summary reports ${ }^{7}$ and from handwritten notes by the Environmental Monitoring staff. 


\section{INTRODUCTION}

Brookhaven National Laboratory (BNL) is a scientific research center situated in Suffolk County on Long Island, about 70 miles east of New York City. Its location and the surrounding communities are shown in Figure 1. During 1967 to 1970, the largest nearby populations were the shoreline communities. The land area within ten miles of BNL was mostly forested or under cultivation.

Figure 2 shows the BNL site and the principal sources of environmental radiation, as well as monitoring stations. During the period covered by this report (1967-70), the site was expanded from about 3,600 acres to about 5,300 acres (as shown in Figure 2). Most of the site is wooded, except for a central area of less than 1,000 acres. The terrain is gently rolling, with elevations varying between 40 and 120 feet above sea level. The land area lies on the west rim of the shallow Peconic River watershed, with the River itself rising in marshy areas in the north and east sections of the site.

Figure 3 shows the annual wind distribution as observed by the BNL Meteorology Group between 1960 and 1973. In terms of meteorology, BNL can be characterized as a well-ventilated site. Prevailing winds are from the southwest during the summer, from the northwest during the winter, and about equally from these two directions during the spring and fall.

Studies of the hydrology and geology ${ }^{8,9}$ of Long Island in the vicinity of BNL indicate that the top soil of the Pleistocene deposits, which are locally between 100-200 feet thick, is generally sandy and highly permeable. Water penetrates readily and there is little direct runoff into surface streams, except during periods of intense precipitation. The average annual rainfall is about 45 inches per year. This is subsequently about equally divided between evapotranspiration and ground water recharge. As indicated in Figure 4, the ground water in the BNL region moves predominantly to the south. This flow is modified toward a more easterly direction in the Peconic River watershed portion of the site.

During 1967 to 1970 , a wide variety of scientific programs were conducted at BNL, including research or development in the following areas:

1. Structure and properties of matter,

2. Physical, chemical, and biological effects of radiation,

3. Radioisotope production and other nuclear applications,

4. Nonweapons-related nuclear and other energy-related technology,

5. Energy sources, transmission, and utilization, including their environmental effects. 
Krojeroqe

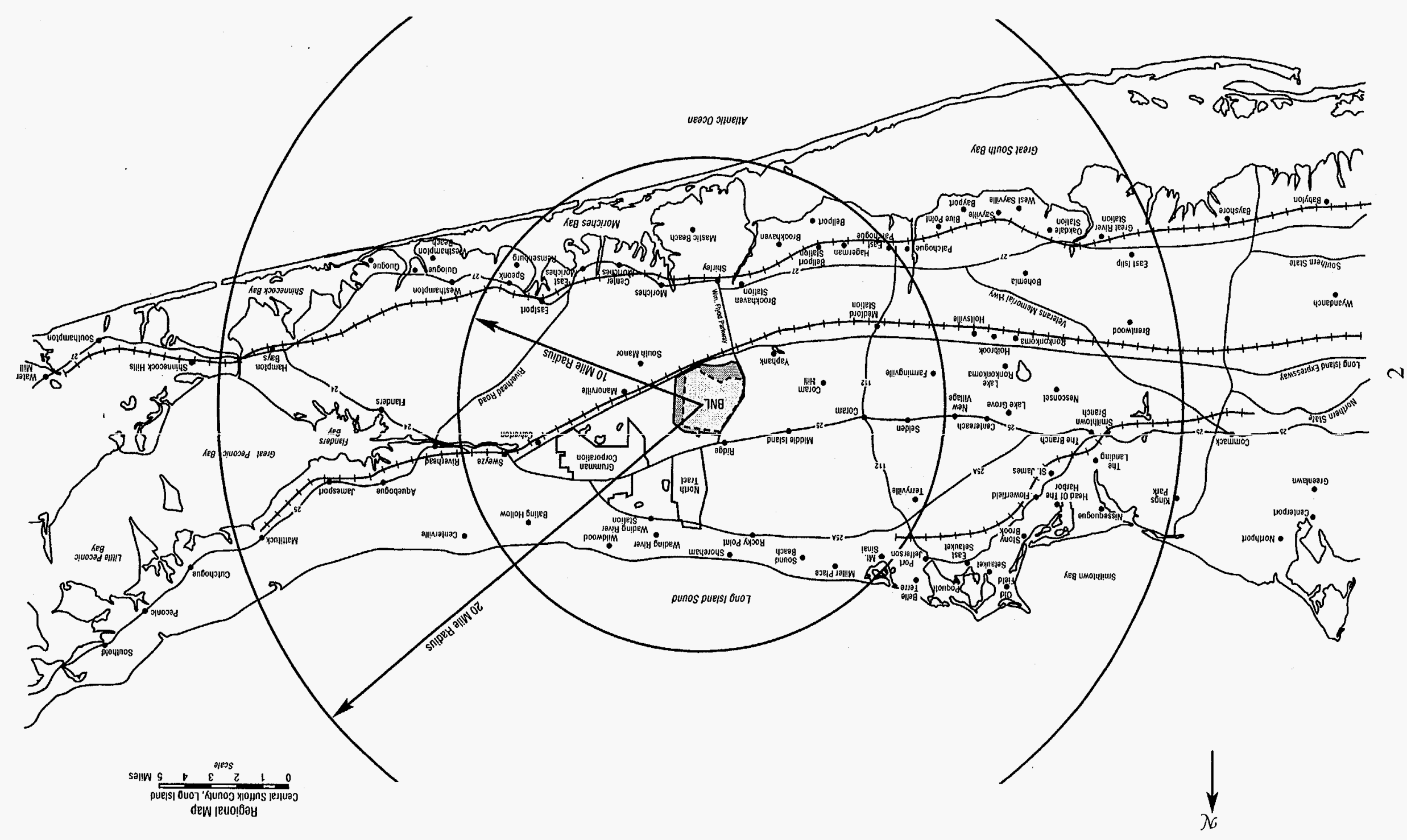




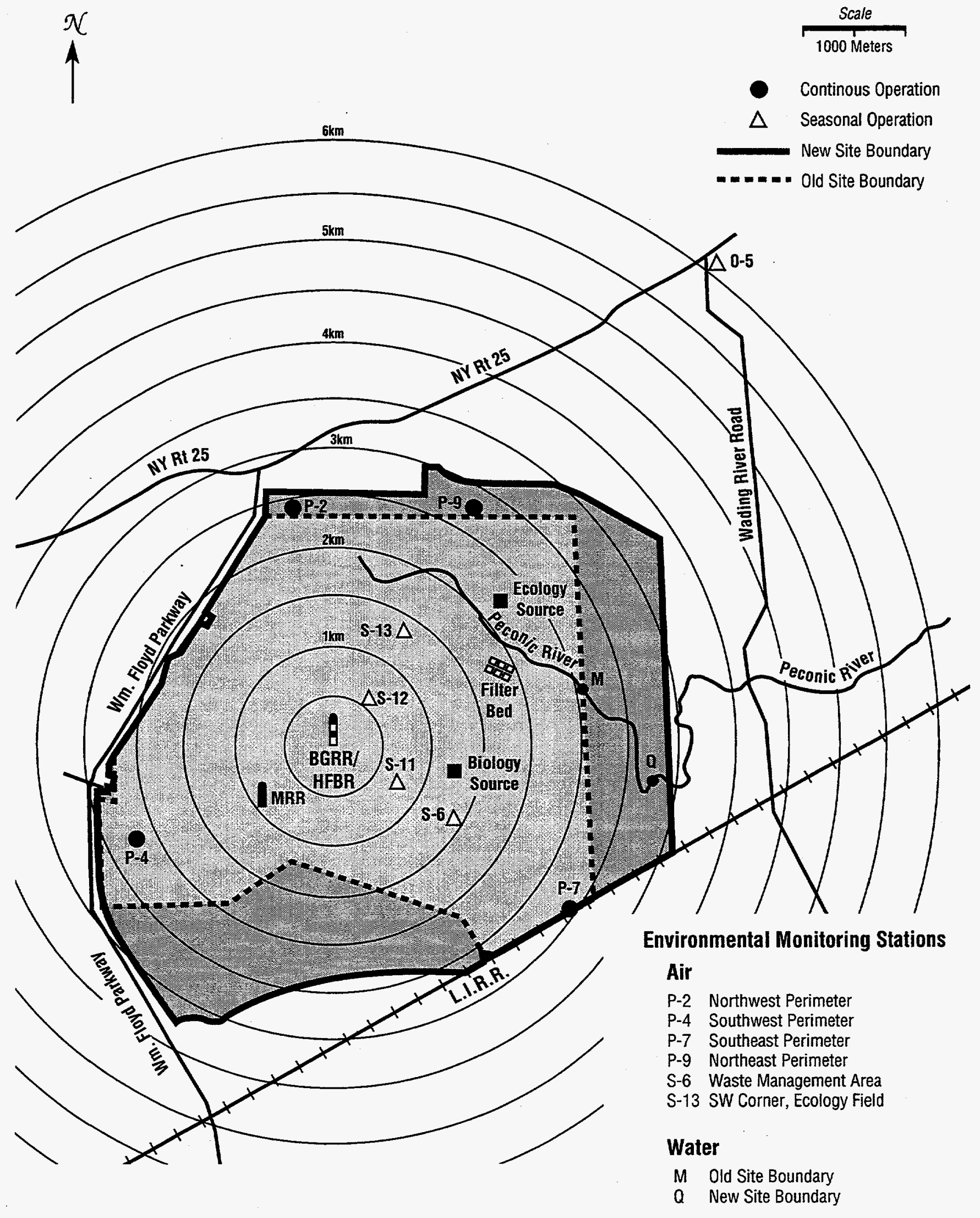

Figure 2. Principal Laboratory Sources of and Monitoring Stations for Environmental Radiation 
STATION: BROOKHAVEN NATIONAL LABORATORY HEIGHT: $\quad 355 \mathrm{ft}$.

PERIOD: January-December, 1960-73

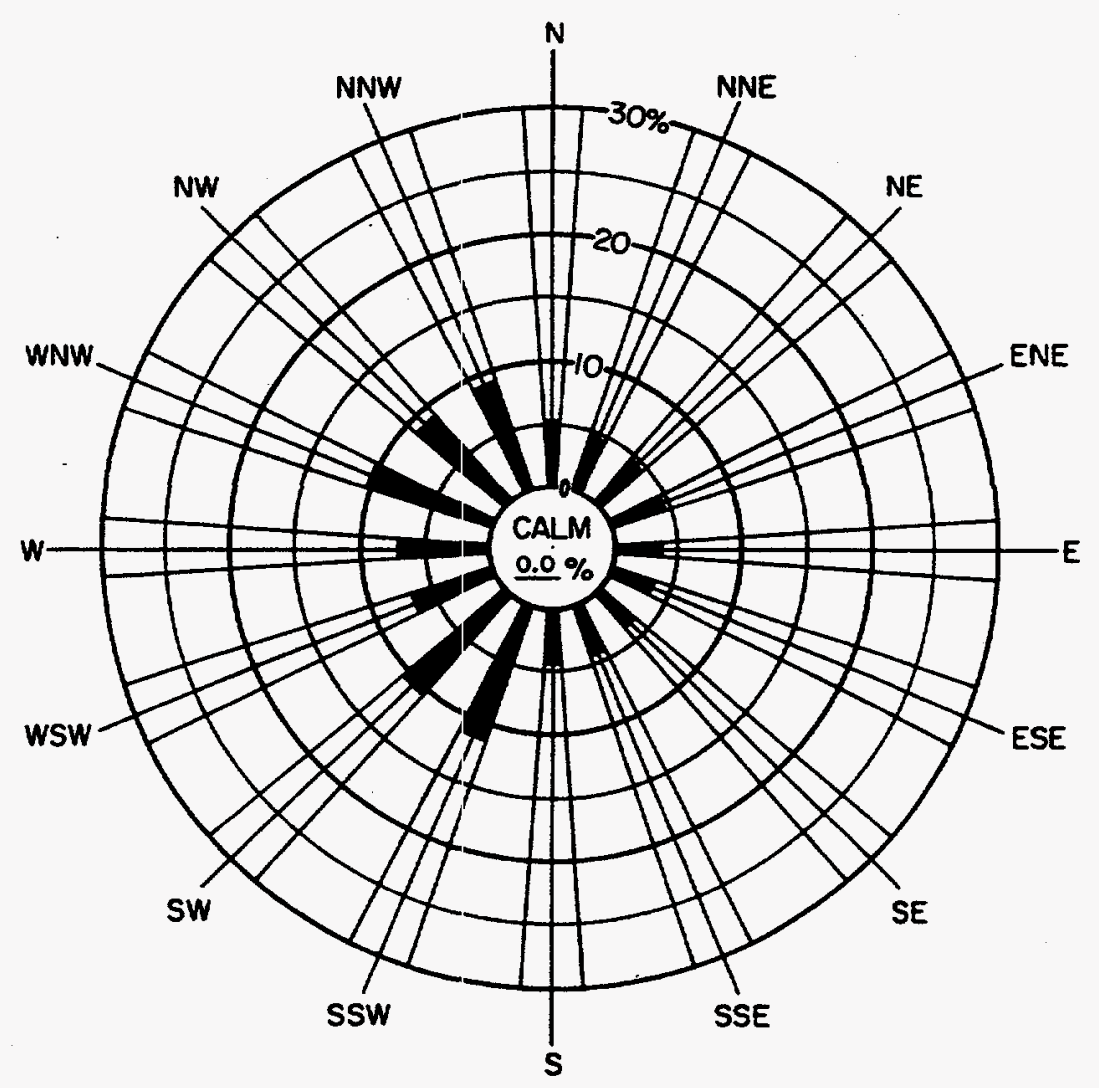

Figure 3. Annual Wind Distribution, 1960-73

Notes:

1. The arrow heads formed by the wedges indicate the direction that the wind blew towards. This diagram indicates that the predominant wind directions were towards the north-northeast and east-southeast.

2. Each concentric circle represents a $5 \%$ frequency, so, for example, the wind blew towards the NEE approximately $12 \%$ of the time. 


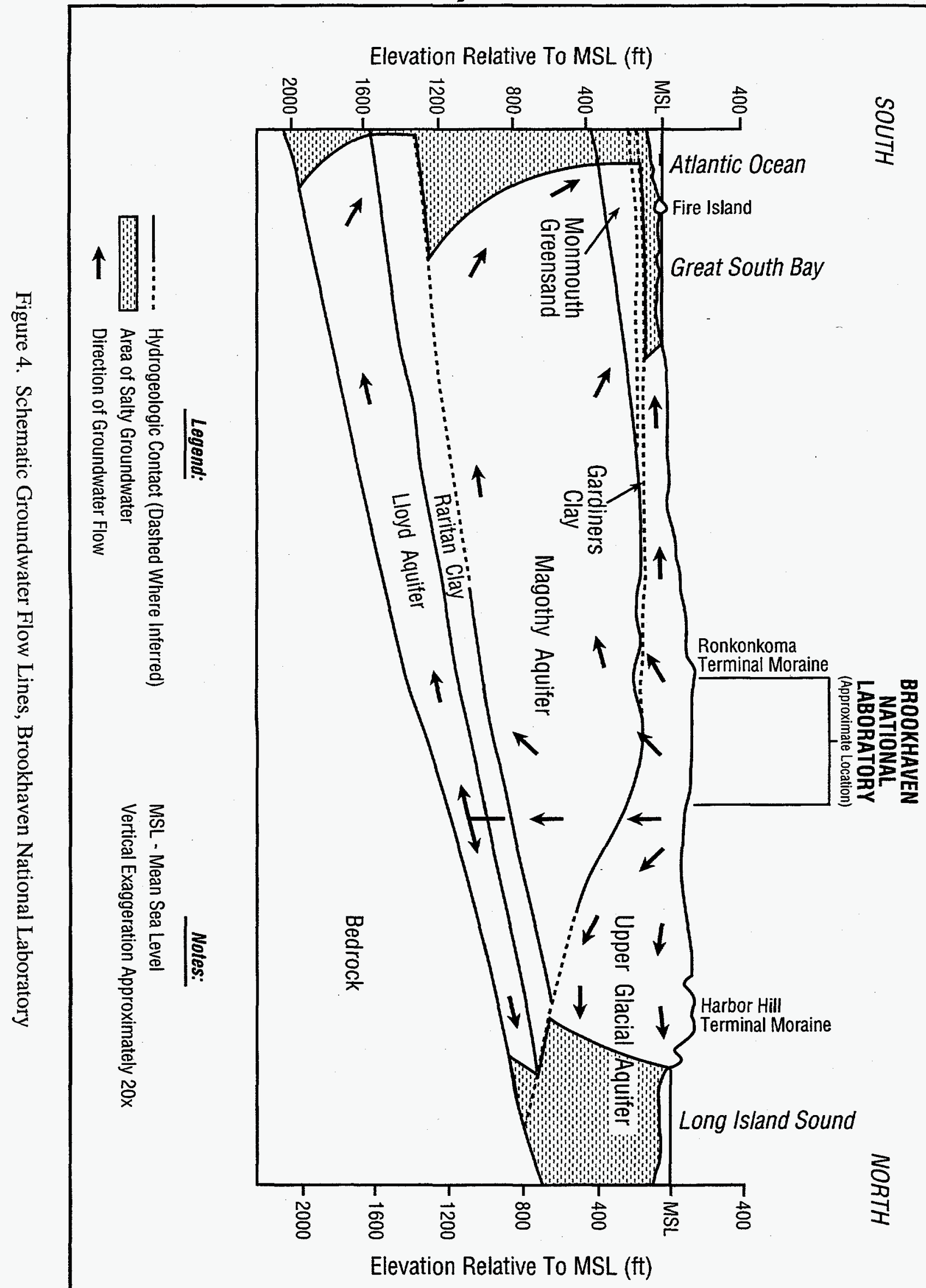


Among the major scientific facilities operated at BNL to carry out the above programs during the period covered by this report were:

1. The High Flux Beam Reactor (HFBR). Fueled with enriched uranium, it is heavywater moderated and cooled, and operated in 1967-70 at a routine power level of 40 MW.

2. The Medical Research Reactor (MRR) is an integral part of the Medical Research Center (MRC). It is an enriched-uranium fueled, natural-water moderated and cooled, and was operated intermittently at power levels up to $3 \mathrm{MW}$.

3. The Brookhaven Graphite Research Reactor (BGRR). It was fueled with enriched uranium with a graphite moderator and reflector. It was air-cooled and had a routine power level of about $20 \mathrm{MW}$. The BGRR went on standby status in June 1968 and subsequently operated only intermittently at reduced power levels during November 1968. It operated occasionally for the first six months of 1969, then ran at essentially zero power levels for training and testing purposes until September, after which it was permanently shut down.

4. The Alternating Gradient Synchrotron (AGS) is a proton accelerator which operated in 1967-70 at energies up to $33 \mathrm{GeV}$.

5. The 60-inch Cyclotron, Research Van de Graaff, Vertical Accelerator, and Chemistry Van de Graaff were used for research and for special isotope production.

Other programs involving irradiations and the use of radionuclides for scientific investigations were carried out at other BNL facilities, including the Medical Research Center, the Biology Department (including two multi-curie field-irradiation sources), the Chemistry Department, and the Department of Nuclear Engineering. The latter included the Hot Laboratory, where special-purpose radioisotopes produced were processed for on- and off-site use.

Most of the airborne radioactive effluents at BNL originated from the BGRR, HFBR, and MRR, with smaller contributions from the Research Van de Graaff and the Chemistry and Medical Research Centers. The BGRR and HFBR also contributed to BNL's liquid radioactive effluents. Additional contributions originated from the Medical Research Center, the Hot Laboratory complex, as well as from decontamination and hot-laundry operations. 


\section{MEASUREMENTS AND ASSESSMENTS}

The measurements and assessments of radioactivity in air and water and levels of external radiation exposure in the vicinity of BNL include those levels associated with naturally occurring radioactive elements and cosmic radiation, those resulting from fallout from atmospheric nuclear weapons tests, and those attributable to the operations of BNL. Table 1 briefly summarizes the applicable radiation protection standards in effect during the period covered by this report.

Table 1. Radiation Protection Guides Reflected in this Report*

\begin{tabular}{|l|l|}
\hline 1. External radiation limit for members of the public & $500 \mathrm{mrem} / \mathrm{y}$ \\
\hline 2. Average airborne ${ }^{131} \mathrm{I}$ limit for continuous exposure of the public & $100 \mathrm{pCi} / \mathrm{m}^{3}$ \\
\hline 3. Airborne tritiated water limit for continuous exposure of the public & $2 \times 10^{5} \mathrm{pCi} / \mathrm{m}^{3}$ \\
\hline 4. Limit for concentration in water for the public & $\begin{array}{c}\text { 1. Gross Beta } \\
\text { Emitters } \\
\text { (unidentified) } \\
3 \times 10^{3} \mathrm{pCi} / \ell \\
\end{array}$ \\
$\begin{array}{l}\text { 2. Tritiated Water } \\
3 \times 10^{6} \mathrm{pCi} / \ell\end{array}$ \\
\hline
\end{tabular}

*Taken from Standards for Radiation Protection (U.S. AEC Manual, Chapter 0524, 1968) ${ }^{10}$.

While the natural radioactivity levels were quite consistent, those associated with atmospheric weapons tests were highly variable. For example, during 1967 to 1970, fallout from two Chinese atmospheric nuclear weapons tests, one on December 24, 1967 and one on December 28, 1968, elevated the radioactive material measurements in the air-particulate samples significantly over the succeeding months. Impacts were also evident from Chinese weapons tests of October 27, 1966, December 28, 1966, January 17, 1967, September 29, 1969, and October 4, 1970.

In an attempt to reflect the uncertainty in measured and calculated values in this report, they are given to only two significant figures.

\subsection{External Radiation}

External radiation is an expression used to denote exposure to man from radioactive sources outside the body, as opposed to internal exposure, which results from exposure to radioactivity within the body. 
External radiation levels, including natural background (as influenced by fallout) and the increments attributable to reactor cooling-air effluent and to the multicurie field gamma sources, were monitored continuously at six fixed monitoring stations. As shown in Figure 2, one of these stations was on site and four were at the perimeter. Off-site station O-6 was located $8.7 \mathrm{~km}$ north of the BGRR-HFBR stack.

Each station's equipment included an ion chamber and dynamic capacitor electrometer assembly, described in detail elsewhere. ${ }^{11}$ These units were capable of accurately measuring less than $10 \mu \mathrm{R} / \mathrm{hr}$ and of detecting changes of the order of $1 \mu \mathrm{R} / \mathrm{hr}$. Although information about the instantaneous dose rates up to about $0.5 \mathrm{mR} / \mathrm{hr}$ could have been obtained from these units, normally the integrated radiation over 4-hour periods was used to obtain weekly averages. These, in turn, were used to compute the monthly data tabulated in this report.

Natural background at a given station, excluding radon and its progeny, was determined from the radiation level prevailing when nc obvious BNL contributions were detectable at that station. The potential error in making this determination was minimized by reference to meteorological data (to establish the direction of the reactor plume) and to the log book indications of the gamma field sources. These background measurements are approximately $30 \%$ higher than the values obtained today because many of the weapons fallout radionuclides with short and intermediate half-lives have decayed away, and the detectors used during the period covered by this report contained small quantities of naturally occurring radionuclides in the insulating material of the ion chamber.

The only measurable increase in external radiation above natural background attributable to BNL operations at most of the monitoring stations was caused by the radioactive ${ }^{41} \mathrm{Ar}$ component of the BGRR effluent cooling air.

Two multicurie field gamma sources were routinely exposed $20 \mathrm{hr} /$ day. One, a ${ }^{60} \mathrm{Co}$ source that contained about $3,600 \mathrm{Ci}$, was used primarily for plant irradiations in a cultivated plot. The other, a ${ }^{137} \mathrm{Cs}$ source that contained about $8,000 \mathrm{Ci}$, was used to irradiate an otherwise undisturbed wooded area for ecological studies (the Ecology Forest). The ${ }^{137} \mathrm{Cs}$ source produced a measurable dose rate at stations $P-9$ and $S-13$. Monthly average radiation levels at these stations attributable to the sources are given in this report. Their locations are shown in Figure 2.

The exposure values for external radiation are given in millroentgens $(\mathrm{mR})$ in the tables. In the text, these values are given in millirem (mrem), primarily to aid in making comparisons with the radiation protection standards.

\subsubsection{7}

The highest annual average perimeter external radiation level attributable to BNL's operations in 1967 was measured at the northeast perimeter station (P-9). It was $101 \mathrm{mrem} / \mathrm{y}$, or 
$20 \%$ of the applicable radiation protection guide of $500 \mathrm{mrem} / \mathrm{y} .{ }^{12}$ The contributors to this exposure were the ${ }^{41} \mathrm{Ar}$ releases from the BGRR and the Ecology Forest ${ }^{137} \mathrm{Cs}$ source (Table A-1).

The external exposure from natural sources and weapons testing fallout averaged 95 $\mathrm{mrem} / \mathrm{y}$ (Table A-1).

\subsubsection{8}

In 1968, the external radiation level at the northeast perimeter due to BNL operations was about $93 \mathrm{mrem} / \mathrm{y}$, or $18 \%$ of the applicable radiation protection guide. The lower level in 1968 compared to 1967 resulted from decreases in radiation from ${ }^{41} \mathrm{Ar}$ after the BGRR was placed on standby status in mid-June. Thereafter, it operated only during several days in November at low power levels (Table B-1).

The contributions to external exposure from natural radiation sources and weapons testing fallout averaged $95 \mathrm{mrem} / \mathrm{y}$ (Table B-1).

\subsection{3 $\underline{1969}$}

In 1969, as a result of the expansion of the Laboratory site, BNL's northeast perimeter was relocated about 775 feet north. The exposure rate at the new perimeter which was due to the Ecology Forest source was determined with portable instruments to be approximately $20 \%$ of that measured at station P-9, which remained at the former perimeter. Although some reduction should be applicable to estimate the ${ }^{41} \mathrm{Ar}$ site perimeter exposure, the analysis is less certain, so the measured values at station P-9 are used as the estimate of the ${ }^{41} \mathrm{Ar}$ exposure levels at the new site perimeter. In addition, the BGRR ran at reduced power levels for parts of January, February, March, May, and June, and at essentially zero power levels through September. Due to these changes, the external radiation levels at the northeast perimeter in 1969 attributable to BNL operations was approximately $18 \mathrm{mrem} / \mathrm{y}(20 \%$ of $84 \mathrm{mrem} / \mathrm{y}$ at station P-9 due to the Ecology Forest, plus $1 \mathrm{mrem} / \mathrm{y}$ from ${ }^{41} \mathrm{Ar}$ ) (Table C-1), or $3.6 \%$ of the applicable radiation protection guide.

The external exposure from natural sources and weapons testing fallout averaged 89 $\mathrm{mrem} / \mathrm{y}$ (Table C-1).

\subsubsection{0}

In 1970, the external radiation level at the new northeast perimeter attributable to BNL operations resulted from the Ecology Forest source. The annual external exposure was about 17 mrem (Table D-1), or 3.4\% of the applicable radiation protection guide. 
The resulting average perimeter value from natural and weapons testing fallout for 1970 was approximately 95 mrem (Table D-1).

\subsection{Environmental Airborne Particulate Radionuclides}

"High volume" (20 ft $3 / \mathrm{min}$ ) positive displacement air pumps (Gast 3040) were operated at monitoring stations P-4, P-7, P-9, and S-13 (Figure 2). The air sampling media consisted of a 3-inch diameter air-particulate filter followed by a 3 " x 1 " bed of charcoal for sampling of radiohalogens. The samples were changed and counted on a two-week basis. After allowing several days for the decay of short-lived natural radioactivity, gross beta counts were made using a 5-inch beta scintillator.

These measurement techniques were designed and developed primarily to monitor fallout deposition and to detect unusual releases to the environment from BNL operations. Therefore, the sensitivity of the system and the overwhelming influence of weapons tests fallout made it virtually impossible to utilize routine field measurements to estimate emissions of other than the

${ }^{41} \mathrm{Ar}$ from the BGRR-HFBR stack.

\subsubsection{7}

In 1967, air-particulate filter samples at all stations at BNL indicated that the gross beta concentration averaged $0.24 \mathrm{pCi} / \mathrm{m}^{3}$ over the year (Table A-2). The somewhat higher concentrations seen early in 1967 reflect the effect of Chinese weapons tests of October 1966, December 1966, and January 1967. The similar increase in concentrations in December reflects a Chinese weapons test in late 1967.

\subsubsection{8}

In 1968, air-particulate filter samples at all stations at BNL showed that the gross beta concentration averaged $0.24 \mathrm{pCi} / \mathrm{m}^{3}$ over the year (Table B-2). During 1968 , the gross beta particulate concentrations remained rather constant, which reflected the absence of an atmospheric weapons test in 1968 . However, low levels of weapons test fallout continued to be seen. This resulted from the debris from the 1966 and 1967 weapons tests having been injected into the stratosphere where it had been circulated around the world. Eventually, this material enters the lower atmosphere where deposition is enhanced.

\subsubsection{9}

In 1969, air-particulate filter samples at all stations at BNL recorded a gross beta concentration that averaged $0.22 \mathrm{pCi} / \mathrm{m}^{3}$ over the year (Table C-2). During 1969 , the transfer of fallout material from the stratosphere to the lower atmosphere, which was enhanced during the 
summer months, resulted in somewhat higher concentrations in August. By this time, the BGRR had ceased operation.

\subsubsection{0}

In 1970, air-particulate filter samples at the monitoring stations indicated that the gross beta concentration at all stations averaged $0.21 \mathrm{pCi} / \mathrm{m}^{3}$ (Table D-2). The occurrence of measurable quantities of gross beta particulate activity in 1970 is the clearest indication that fallout produced from weapons tests was the source of this radioactivity.

\subsection{Radionuclides in Precipitation}

Since the early 1950 s, BNL has participated in a nationwide network of fallout monitoring stations. An important part of this effort was the measurement of activity deposited in rain, snow, and settled dust.

Two pot-type rain collectors, each with a surface area of $0.33 \mathrm{~m}^{2}$, were situated adjacent to the Meteorology Building, 1,300 $\mathrm{m}$ and $90^{\circ}$ west of the BGRR-HFBR stack. This location was chosen to minimize the possible effect of releases from the BGRR-HFBR stack in assessing the fallout produced from weapons tests. Two routine collections were made. A sample from one collector was picked up at 0900 only if precipitation had been observed during the previous 24 hours (or weekend); the other was picked up each Monday morning whether or not precipitation had occurred. A standard amount of distilled water was used to wash down the collector if no precipitation was falling at the time the sample was terminated.

Part of each collection was evaporated for gross beta counting. Weekly samples were analyzed for identifiable gamma-emitting isotopes and monthly composite samples for ${ }^{89} \mathrm{Sr}$ and ${ }^{90} \mathrm{Sr}$. The monthly averages for gross beta activity and for individual isotopes in precipitation are given in this report (Tables A-3, B-3, C-3, and D-3).

\subsubsection{7}

Radioactivity measurements of rain and settled dust samples for 1967 are given in Table A-3. The yearly total gross beta activity deposited at the sampling stations averaged $2.1 \times 10^{3} \mathrm{nCi} / \mathrm{m}^{2}$. The unusually large deposition in January and December correlated closely with the Chinese weapons tests of December 28, 1966 and December 24, 1967.

\subsubsection{8}

Radiation measurements for 1968 of rain and settled dust are given in Table B-3. The yearly gross beta activity deposited at the sampling stations totaled $84 \mathrm{nCi} / \mathrm{m}^{2}$. 


\subsubsection{9}

Radioactivity measurements for 1969 of rain and settled dust are given in Table C-3. The yearly total gross beta activity deposited at the sampling stations totaled $83 \mathrm{nCi} / \mathrm{m}^{2}$.

\subsubsection{0}

Radioactivity measurements for 1970 of rain and settled dust are given in Table D-3. The yearly gross beta activity deposited at the sampling stations totaled $74 \mathrm{nCi} / \mathrm{m}^{2}$.

These values were consistent with measurements of atmospheric fallout in the northeastern part of the United States. In particular, as with the data for the gross beta concentrations given in section 2.2, they correlated with the Chinese weapons tests which occurred on October 27, 1966, December 28, 1966, January 17, 1967, December 24, 1967, December 28 and 29, 1969, and October 14, 1970. 


\section{CORRELATION OF BGRR-HFBR STACK RELEASES AND ENVIRONMENTAL EXPOSURES}

Routine monitoring of the BGRR-HFBR stack effluent was conducted by the Reactor Health Physics Group. The equipment used included an air-particulate sampler with a continuous tape of filter medium (HV-70), and a beta scintillation detector which was positioned to measure the air particulate gross beta activity which had been collected on the filter medium twenty minutes earlier. In addition, a Sill-type charcoal cartridge ${ }^{13}$ which was routinely changed every other day and counted in a $\mathrm{NaI}$ well detector one week post-collection was used to determine ${ }^{131} \mathrm{I}$ effluent concentrations. A silica-gel trap was used to collect water vapor for weekly liquid scintillation analysis for tritiated water. The average monthly gross beta, ${ }^{131} \mathrm{I}$, and tritiated water concentrations in the BGRR-HFBR stack effluent, as established by this routine sampling program, are given in Tables A-4, B-4, C-4, and D-4.

Note particularly that ${ }^{131} \mathrm{I},{ }^{41} \mathrm{Ar}$, and particulate gross beta activity track very closely with the BGRR's operating schedule, which ended almost completely in late June 1968, while the tritiated water vapor (HTO) releases corresponded only broadly with the HFBR operating history since these releases occurred primarily as a result of maintenance activities.

The 1966 Environmental Monitoring Report ${ }^{5}$ discussed the results of a detailed study that explored the relationship between measured releases from the BGRR-HFBR stack and the environmental airborne concentrations. ${ }^{14}$ Argon-41 emissions were not included in this study since these exposures were measured directly.

\subsection{Iodine-131}

Aside from ${ }^{41} \mathrm{Ar},{ }^{131} \mathrm{I}$ was the most important radionuclide discharged to the atmosphere from the BGRR. The 1966 report indicated that ${ }^{82} \mathrm{Br}$ and ${ }^{133} \mathrm{I}$ were released in somewhat larger concentrations. However, calculations indicate that due to their shorter half-life and other dosimetric properties, the resulting doses from ${ }^{133} \mathrm{I}$ would have been about half that of ${ }^{131} \mathrm{I}$, and the doses from ${ }^{82} \mathrm{Br}$ less than $20 \%$ of the ${ }^{131} \mathrm{r}$.

In $1966,2,500 \mathrm{mCi}$ of ${ }^{131}$ I were emitted from the BGRR-HFBR stack, with the resulting highest average annual concentration at the northeast site perimeter station being $0.0042 \mathrm{pCi} / \mathrm{m}^{3} .5$ (This value is reasonably close to the value of $0.0029 \mathrm{pCi} / \mathrm{m}^{3}$ obtained using the same source term, together with meteorological transport codes based on measured parameters.) This provides a rough means of calculating the concentration at the site perimeter, which could be expected from a given annual release of ${ }^{131} \mathrm{I}$. This technique suggested that a perimeter concentration of about $2 \times 10^{-6} \mathrm{pCi} / \mathrm{m}^{3}$ could have been expected if $1 \mathrm{mCi}$ of ${ }^{131} \mathrm{I}$ were released from the BGRR-HFBR stack. 


\subsubsection{7}

In $1967,570 \mathrm{mCi}$ of ${ }^{131}$ I were released from the BGRR-HFBR stack (Table A-4). This implies an average annual concentration of approximately $0.0012 \mathrm{pCi} / \mathrm{m}^{3}$ at the perimeter of the site (station P-9), which is $.0012 \%$ of the applicable radiation protection guide of $100 \mathrm{pCi} / \mathrm{m}^{3}$.

\subsubsection{8}

In 1968, 120 mCi of ${ }^{131}$ I were released from BGRR-HFBR stack (Table B-4). This implies an average annual concentration of approximately $0.00024 \mathrm{pCi} / \mathrm{m}^{3}$ at station $\mathrm{P}-9$. This was approximately $0.00024 \%$ of the applicable radiation protection guide.

\subsubsection{9}

In 1969, approximately $7.6 \mathrm{mCi}$ of ${ }^{131}$ I were released from the BGRR-HFBR stack (Table C-4). This implies an average annual concentration of approximately $0.000015 \mathrm{pCj} / \mathrm{m}^{3}$ at station P-9. This was approximately $.000015 \%$ of the applicable radiation protection guide.

\subsection{4 $\underline{1970}$}

In 1970, there was no longer a measurable release of ${ }^{131}$ I from the BGRR-HFBR stack. This result, together with the lower levels in 1968 and 1969 compared with 1967, reflect the phase-out of BGRR operations.

\subsection{Particulate Gross Beta Activity}

Fallout from nuclear weapons tests obscured the contributions of any airborne particulate gross beta activity from BNL operations as measured at the field stations. However, in 1966, as part of a detailed analysis of particulate activity released from the stack, gamma-emitting radionuclides in air samples from the stack were analyzed daily. That study, reported in detail in the 1966 Environmental Monitoring Report, ${ }^{5}$ showed that the gross beta particulate activity results primarily from short-lived radioactivity. For example, in 1966, the particulate activity discharged from the BGRR-HFBR stack was $323 \mathrm{Ci}$. The daily analysis showed that less than $0.2 \mathrm{Ci}$ (about $0.06 \%$ ) of this total was due to intermediate- and long-lived radionuclides, i.e., those with half-lives of several hours to many days. ${ }^{15}$ The field-station values seen in 1966 were dominated by weapons testing fallout. Iodine-131, ${ }^{133} \mathrm{I},{ }^{82} \mathrm{Br}$, and ${ }^{41} \mathrm{Ar}$ were the only radionuclides attributable to $\mathrm{BNL}$ operations which were discernible at the field stations. 


\subsection{Tritiated Water Vapor}

The predominant source of tritiated water vapor in the BGRR-HFBR stack effluent was due to HFBR operations and maintenance. During the period covered by this report, field techniques for monitoring tritiated water vapor were under development so there were no reliable measurements. However, the 1974 Environmental Monitoring Report ${ }^{16}$ gave the first available measurements of tritiated water vapor at the field stations. That data can be used to estimate airborne tritiated water concentrations as a result of releases in 1967-70. In Table II of that report, tritium release values are given for several BNL facilities, each with different stack heights. Approximately $430 \mathrm{Ci}$ of tritiated water vapor were released from these various stacks with heights ranging from 45 to 320 feet. About $300 \mathrm{Ci}$ of tritiated water vapor were released from the BGRR-HFBR stack (320 feet). As a conservative approximation, a correlation can be made between the $300 \mathrm{Ci}$ emitted from the stack in 1974 and the average ground-level concentrations measured at the site perimeter stations given in Table VI of that 1974 report. The average concentration at the southwest and northeast perimeter stations was about $35 \mathrm{pCi} / \mathrm{m}^{3}$. This would suggest that for each curie of tritiated water vapor emitted from the BGRR-HFBR stack, the average air concentration would be $0.12 \mathrm{pCi} / \mathrm{m}^{3}\left(35 \mathrm{pCi} / \mathrm{m}^{3}\right.$ divided by $\left.300 \mathrm{Ci}\right)$ at the perimeter stations. This approach will overestimate the concentration per curie emitted from the BGRR-HFBR stack, since some of the remaining $130 \mathrm{Ci}$ of the tritiated water vapor which was released at lower elevations may also have been measured at the field stations.

\subsubsection{7}

In $1967,210 \mathrm{Ci}$ of the tritiated water vapor were released from the BGRR-HFBR stack, implying an annual average concentration of less than $25 \mathrm{pCi} / \mathrm{m}^{3}$ at the perimeter of the site (Table A-4). This was approximately .013\% of the applicable radiation protection guide of $2 \times 10^{5} \mathrm{pCi} / \mathrm{m}^{3}$.

\subsubsection{8}

In $1968,380 \mathrm{Ci}$ of the tritiated water vapor were released from the BGRR-HFBR stack, implying an annual average tritiated water vapor concentration of less than $47 \mathrm{pCi} / \mathrm{m}^{3}$ at the perimeter of the site (Table B-4). This was approximately $.024 \%$ of the applicable radiation protection guide.

\subsubsection{9}

In $1969,380 \mathrm{Ci}$ of the tritiated water vapor were released from the BGRR-HFBR stack; from this we deduce an annual average tritiated water vapor concentration of less than $45 \mathrm{pCi} / \mathrm{m}^{3}$ at the perimeter of the site (Table C-4), approximately .023\% of the applicable radiation protection guide. 


\subsection{4 $\underline{1970}$}

In $1970,690 \mathrm{Ci}$ of the tritiated water vapor were released from the BGRR-HFBR stack. This implies an annual average tritiated water vapor concentration of less than $83 \mathrm{pCi} / \mathrm{m}^{3}$ at the perimeter of the site (Table D-4), approximately $0.042 \%$ of the applicable radiation protection guide.

A major fraction of the tritiated water vapor released in $1970(\sim 240 \mathrm{Ci})$ took place between January 5 and January 12, 1970 when the Reactor heat exchanger was repaired. To evaluate the ground-level deposition of this release, samples of hard-packed snow (which had fallen on January 6-7) were taken at $40^{\circ}$ intervals on arcs of 500,1,000,2,000, 4,000, and 5,000 meters from the stack. A well-defined pattern of deposition existed both on and off the BNL site. The snow samples were melted and the activity levels reported in $\mathrm{pCi} / \ell$. The liquid concentration was at a maximum for snow obtained adjacent to Building 535 ( $\sim 500$ meters southeast of the Reactor stack) with a value of $35,000 \mathrm{pCi} / \mathrm{l}$. The pattern of deposition indicated that the concentrations in water from melted snow off the Laboratory site would be less than $3,000 \mathrm{pCi} / \mathrm{l}$. The highest value measured in water obtained from melted snow off-site was $\sim 2,000 \mathrm{pCi} / \ell$. This sample was obtained from a location 4,000 meters south-southeast of the Reactor stack. 


\section{RADIOACTIVITY IN LIQUID EFFLUENTS}

\subsection{Liquid Waste System}

Small amounts of low-level radioactive liquid wastes were routinely disposed of by release into the Laboratory's sanitary waste system, where they were diluted by a large volume of uncontaminated water. This liquid waste passed through an Imhoff Tank or the Clarifier, which removed most of the solids. The effluent flowed onto sand filter-beds, from which most of it was directed by an underlying tile field, chlorinated, and discharged into a small stream which forms one of the headwaters of the Peconic River.

The pathway indicated by the dashed lines at the Sewage Treatment Plant in Figure 5 reflects the situation until late 1967 when the effluent stream was redirected through a newly installed Clarifier as shown by the solid line through the Sewage Treatment Plant.

The schematic illustration of the sewage treatment plant, shown in Figure 5, includes the related monitoring arrangements. In addition to the in-plant flow measurement and sampling instrumentation, totalizing flow meters (Leopold \& Stevens TF 61-2), which include provision for actuating a sampler with each 2,000 gallons of flow in combination with a positive-action battery-operated sampler (Brailsford DU-1), were installed at the Chlorinating Plant at the former site perimeter 0.5 miles downstream on the Peconic, and in 1969 at the present site perimeter (1.6 miles downstream).

For 1967 , the only available tritiated water concentrations were at the former perimeter (station $\mathrm{M}$ ). These same concentrations were used at station $\mathrm{Q}$. For estimating the tritiated water concentrations at the Imhoff Tank/Clarifier and at the Chlorinating Plant, the concentrations at station $\mathrm{M}$ and $\mathrm{Q}$ were adjusted to reflect additional upstream flow.

\subsubsection{7}

In 1967, the total waste-water flow as measured at the Imhoff Tank/Clarifier was approximately $1.2 \times 10^{9}$ liters (approximately 300 million gallons). About $89 \%$ of the liquid effluent discharged onto the sand filter-beds at the Sewage Treatment Plant was directed to the headwaters of the Peconic River as measured at the Chlorinating Plant.

The concentration of gross beta emitters in the effluent discharged onto the sand filterbeds was $68 \mathrm{pCi} / \ell$, and the tritiated water concentration was $\sim 11,000 \mathrm{pCi} / \ell$ (Table A-5).

The concentration of gross beta emitters in the water released to the headwaters of the Peconic River (at the Chlorinating Plant) was $46 \mathrm{pCi} / \ell$ (Table A-6), which was $1.5 \%$ of the applicable radiation protection guide of $3,000 \mathrm{pCi} / \ell$. The tritiated water concentration was $\sim 10,000 \mathrm{pCi} / \ell$ (Table A-6), which was $0.3 \%$ of the applicable radiation protection guide of $3 \times 10^{6} \mathrm{pCi} / \ell$. The change in the concentration of the beta emitters through the sand filter-beds was primarily due to holdup in the top few inches of the beds. 


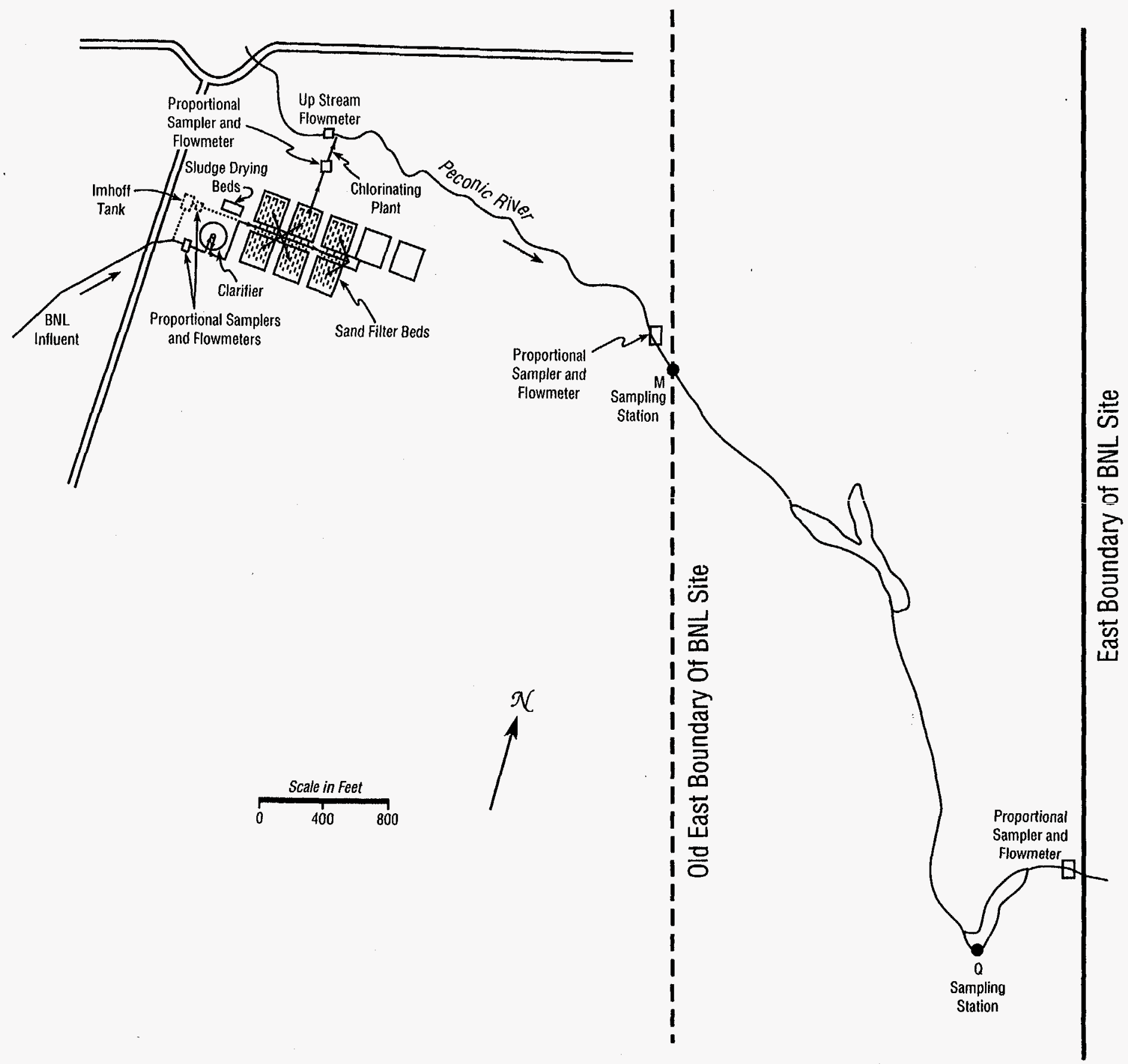

Figure 5. Brookhaven National Laboratory

Sanitary Waste System 
At the site perimeter (station $M$ in 1967), due to upstream flow, the total River flow exceeded the flow at the Chlorinating Plant by about $1.2 \times 10^{7}$ liters (about $0.5 \%$ ). The yearly average concentration of gross beta emitters at station $\mathrm{M}$ was $45 \mathrm{pCi} / \ell$ (Table A-7), which was $1.5 \%$ of the applicable radiation protection guide. The yearly average tritiated water concentration was $9,100 \mathrm{pCi} / \ell$ (Table A-7), which was $0.3 \%$ of the radiation protection guide.

At station Q, the total flow was $.9 \times 10^{9}$ liters. The concentration of gross beta emitters was $49 \mathrm{pCi} / \ell$ (Table A-8), which was $1.6 \%$ of the applicable radiation protection guide. The tritiated water concentration was $9,900 \mathrm{pCi} / 1 \ell$, which was $0.33 \%$ of the radiation protection guide.

The unusually high values for tritiated water in December shown in Tables A-5, A-6, A-7, and A-8 are attributable to a planned release from the Medical Research Center. The unusually high value for gross beta concentrations in March, as shown in Tables A-5, A-6, and A-7 are attributable to an unplanned release of Tungsten-185 from the Metallurgy Building (Building 480).

\subsubsection{8}

In 1968 , of the total waste-water flow discharged onto the sand filter-beds of $1.5 \times 10^{9}$ liters (396 million gallons), 77\% was directed to the headwaters of the Peconic River. The concentration of gross beta emitters in the effluent discharged onto the sand filter-beds was $15 \mathrm{pCi} / \ell$, and the average tritiated water concentration was $15,000 \mathrm{pCi} / \ell$ (Table B-5).

The concentration of gross beta emitters in the water released to the headwaters of the Peconic River (at the Chlorinating Plant) was $16 \mathrm{pCi} / \ell$ (Table B-6), which was $0.53 \%$ of the applicable radiation protection guide of $3,000 \mathrm{pCi} / \ell$; and the tritiated water concentration was $13,000 \mathrm{pCi} / \ell$ (Table B-6), which was $0.44 \%$ of the applicable radiation protection guide of $3 \times$ $10^{6} \mathrm{pCi} / \mathrm{l}$.

At the site perimeter station $\mathrm{M}$, the total flow was $1.3 \times 10^{9}$ liters in 1968 . The concentration of the gross beta emitters there was $15 \mathrm{pCi} / \ell$ (Table B-7), which was $0.5 \%$ of the applicable radiation protection guide. The tritiated water concentration was $12,000 \mathrm{pCi} / \ell$ (Table $\mathrm{B}-7$ ), which was $0.4 \%$ of the applicable radiation protection guide.

At station $\mathrm{Q}$, the total flow was $1.0 \times 10^{9}$ liters. The concentration of gross beta emitters was $16 \mathrm{pCi} / \ell$ (Table $\mathrm{B}-8$ ), which was $0.53 \%$ of the applicable radiation protection guide. The tritiated water concentration was $12,000 \mathrm{pCi} / \ell$, which was $0.4 \%$ of the applicable radiation protection guide.

The unusually high values for tritiated water in March, April, September, and October (Tables B-5, B-6, B-7, and B-8) were primarily attributable to the operation of the Evaporator. In October, there was a one-day release of $3.6 \mathrm{Ci}$ from the HFBR, and in November, a one-day release of 1.6 Ci from the Medical Research Center. 


\subsubsection{9}

The total BNL wastewater flow discharged onto the sand filter-beds in 1969 was $1.6 \times 10^{9}$ liters, or 420 million gallons. About $80 \%$ of the volume of the liquid effluent was directed to the headwaters of the Peconic River. The concentration of gross beta emitters in the effluents released to the sand filter-beds was $15 \mathrm{pCi} / \ell$, and the average tritiated water concentration was $11,000 \mathrm{pCi} / \mathrm{l}$ (Table C-5).

The concentration of gross beta emitters in the water released to the headwaters of the Peconic River (at the Chlorinating Plant) was $13 \mathrm{pCi} / \ell$ (Table C-6), which was $0.43 \%$ of the applicable radiation protection guide of $3,000 \mathrm{pCi} / \ell$, and the tritiated water concentration was $12,000 \mathrm{pCi} / \ell$ (Table $\mathrm{C}-6$ ), which was $0.4 \%$ of the applicable radiation protection guide.

In 1969 , the site perimeter and the monitoring station at the site perimeter were moved downstream about 1,000 meters. At this location, station $Q$, the flow is occasionally less than at station $\mathrm{M}$ at the old site perimeter, but the concentration of radionuclides in the remaining surface water was nearly the same. In 1969, the concentration of the gross beta emitters at the former perimeter station $\mathrm{M}$ was $12 \mathrm{pCi} / \ell$ (Table $\mathrm{C}-7$ ), which was $0.39 \%$ of the applicable radiation protection guide. The tritiated water concentration was $11,000 \mathrm{pCi} / \ell$ (Table C-7), which was $0.33 \%$ of the applicable radiation protection guide. At the new site perimeter, station $\mathrm{Q}$, the concentration of the gross beta emitters was $14 \mathrm{pCi} / \ell$ (Table C-8), which was .47\% of the applicable radiation protection guide. The tritiated water concentration was $7,700 \mathrm{pCi} / \ell$ (Table C-8), which was $0.26 \%$ of the applicable radiation protection guide.

The somewhat elevated levels of tritiated water concentration in May are due to a $1.13 \mathrm{Ci}$ "spike" released from the HFBR. In addition, the HFBR released $2.5 \mathrm{Ci}$ in October and $1.34 \mathrm{Ci}$ in November. Evaporator operations during May, July, October, and November contributed to the elevated tritiated water concentration in the effluent stream (Tables C-5, C-6, C-7, and C-8).

\subsubsection{0}

In 1970 , the total waste-water flow at the Clarifier was $1.7 \times 10^{9}$ liters ( 450 million gallons). About $85 \%$ of the total volume of liquid effluent discharged onto the sand filter-beds at the Sewage Treatment Plant was redirected to the headwaters of the Peconic River. The balance is assumed to have percolated into the ground water underlying the bed. The concentration of gross beta emitters in the effluent discharged onto the sand-filter beds was $26 \mathrm{pCi} / \ell$, and the tritiated water concentration was $21,000 \mathrm{pCi} / \ell$ (Table D-5).

The gross concentration of the beta emitters in water released to headwaters of the Peconic River at the Chlorinating Plant was $18 \mathrm{pCi} / \ell$ (Table D-6), which was about $0.6 \%$ of the applicable radiation protection guide. The tritiated water concentration was $21,000 \mathrm{pCi} /$, which was about $0.71 \%$ of the applicable radiation protection guide. 
In 1970 , the concentration of the gross beta emitters at the former perimeter, station $\mathrm{M}$, was $17 \mathrm{pCi} / \ell$ (Table D-7), which was about $0.56 \%$ of the applicable radiation protection guide. The tritiated water concentration was $19,000 \mathrm{pCi} / \ell$ (Table D-7), which was $0.6 \%$ of the applicable radiation protection guide.

At the new perimeter (station $Q$ ), the concentration of the gross beta emitters was 16 $\mathrm{pCi} / \ell$ (Table D-8), which was $0.5 \%$ of the applicable radiation protection guide. The tritiated water concentration was $19,000 \mathrm{pCi} / \ell$ (Table D-8), which was $0.63 \%$ of the applicable radiation protection guide. The unusually high values for the March tritiated water concentration (Tables D-5 to D-7) are attributable to unusually frequent operations at the Waste Concentration Facility during the month $(\sim 9.5 \mathrm{Ci})$. In addition, somewhat smaller contributions resulted from Evaporator operations in February ( $2.4 \mathrm{Ci})$, April $(\sim 2.0 \mathrm{Ci})$, May $(\sim 3.5 \mathrm{Ci})$, June $(\sim 1.8 \mathrm{Ci})$, and October $(\sim 1.4 \mathrm{Ci})$.

\subsection{Peconic River Grab Samples}

Monthly grab water samples were obtained at on- and off-site locations along the upper tributary of the Peconic River, into which BNL routinely discharges low-level radioactive wastes. Reference grab samples were also obtained from other nearby streams and bodies of water outside the Laboratory's drainage area. The sampling locations, as shown in Figure 6, were as follows.

Peconic River, proceeding downstream (within the Laboratory drainage area )

K Peconic River just below BNL effluent outfall

L Peconic River 1,300 ft. below effluent outfall

M Peconic River, 2,600 ft. below BNL effluent outfall (old BNL perimeter)

Q Peconic River, 6,900 ft. downstream from BNL effluent outfall (new BNL perimeter)
A Peconic River at Schultz Road, 15,900 ft. downstream
B Peconic River at Wading River-Manorville Road, 23,100 ft. downstream
C Peconic River at Manorville, 35,000 ft. downstream
D Peconic River at Calverton, 46,700 ft. downstream

Controls (not within the Laboratory drainage area)

E Peconic River, upstream from BNL effluent outfall

F Peconic River, north tributary (independent of BNL drainage)

H Carman's River, outfall of Yaphank Lake

I Artist's Lake (maintained by water table, no surface flow)

J Lake Panamoka (maintained by water table, no surface flow) 


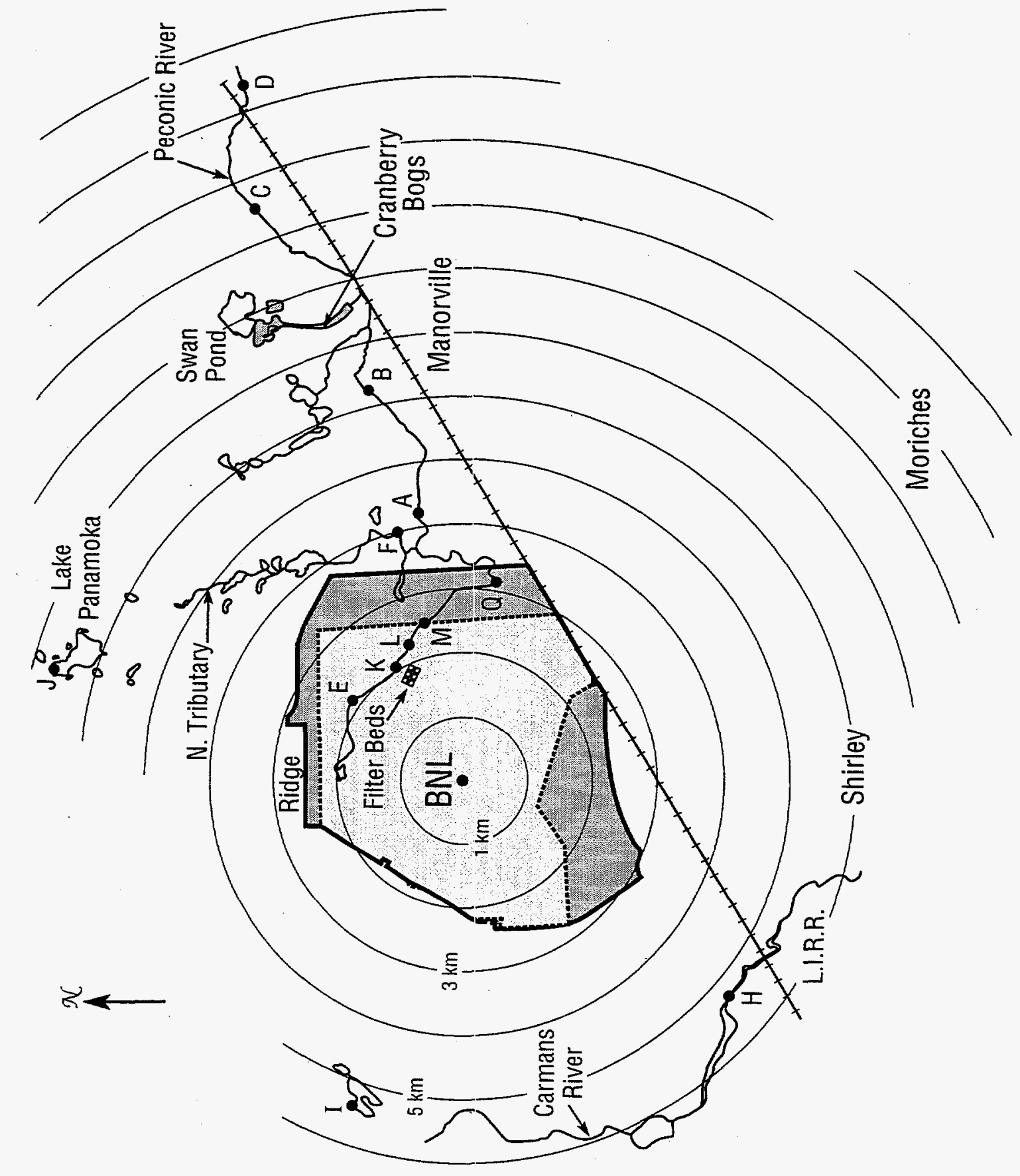

ב⿱艹 
The individual monthly and yearly average gross beta and tritium concentrations at the downstream and control locations are given in Tables A-9, B-9, C-9, and D-9.

\subsubsection{7}

The largest yearly average gross beta concentration seen in monthly grab downstream samples in 1967 was $32 \mathrm{pCi} / \mathrm{l}$ at sampling station K (Table A-9), which was $1.1 \%$ the applicable radiation protection guide. The largest yearly average tritiated water concentration was $<5,900$ pCi/ $\ell$ at sampling station L (Table A-9), which was about $0.2 \%$ of the applicable radiation protection guide. The unexplained high values at station F (Table A-9) for January and March are puzzling since this sampling station is located on a tributary which arises from Lake Panamoka and flows into the Peconic River beyond the site perimeter. A similar question exists for Station I in the first quarter of the year.

\subsubsection{8}

The largest yearly average gross beta concentration seen in monthly grab downstream samples in 1968 was $18 \mathrm{pCi} / \mathrm{l}$ at sampling station Q (Table B-9), which was $0.6 \%$ of the applicable radiation protection guide of $3,000 \mathrm{pCi} / \ell$. The largest yearly average tritiated water concentration was $12,000 \mathrm{pCi} / \mathrm{l}$ at sampling station $\mathrm{M}$ (Table B-9), which is $0.4 \%$ of the applicable radiation protection guide.

\subsection{3 $\underline{1969}$}

The largest yearly average gross beta concentration in monthly grab stream samples in 1969 was $15 \mathrm{pCi} / \mathrm{l}$ at sampling station L (Table C-9), which was $0.5 \%$ of the applicable radiation protection guide. The largest yearly average tritiated water concentration was $27,000 \mathrm{pCi} / \mathrm{l}$ at sampling station Q (Table C-9), which was $0.9 \%$ of the applicable radiation protection guide.

As noted in section 4.1.3, 1.13 $\mathrm{Ci}$ of tritiated water was released from the HFBR on May 5, 1969. The effects of this release are seen in the elevated tritiated water concentrations seen in May at stations $M$ and $Q$.

\subsection{4 $\underline{1970}$}

The largest yearly average gross beta concentration seen in monthly grab stream samples in 1970 was $20 \mathrm{pCi} / \ell$ at sampling station $\mathrm{K}$ (Table D-9), which was $0.7 \%$ of the applicable radiation protection guide. The largest yearly average tritiated water concentration was 24,000 $\mathrm{pCi} / \ell$ at sampling station $\mathrm{M}$ (Table D-9), which was $0.8 \%$ of the applicable radiation protection guide. 
The elevated tritiated water concentrations seen in February and March at stations K, L, $\mathrm{M}$, and $\mathrm{Q}$ are thought to be due to work on the Evaporator Facility.

\subsection{River Bottom, Vegetation, and Fauna Sampling}

Seasonal samples were taken of the Peconic River bottom, vegetation growth in or on the River bank, and fish and other animals in the River habitat.

Seasonal sampling of Peconic River bottom sediments was conducted in March and July 1968 , and in October and November 1969. Peconic River vegetation samples were taken in July 1968 and August 1969, and the fauna were obtained for analysis of gamma-emitting radionuclides in July 1968 and August 1969. In 1968, bottom sediment samples were obtained from the North Lagoon $(N)$ and the AGS-HFBR (O) sumps. The locations of these sumps are shown on Figure 7.

\subsubsection{7}

Data for 1967 could not be located.

\subsubsection{8}

The March 1968 Peconic River bottom sediment samples showed the largest concentration for ${ }^{60} \mathrm{Co}$ at station $\mathrm{M}$, with a value of $24 \mathrm{pCi} / \mathrm{g}$. The largest concentration of ${ }^{137} \mathrm{Cs}$ was also at station M, with a value of $13 \mathrm{pCi} / \mathrm{g}$ (Table B-10). The largest July $1968 \mathrm{River}$ bottom-sample concentrations were at station $\mathrm{M}$, with a value of $11 \mathrm{pCi} / \mathrm{g}$ of ${ }^{60} \mathrm{Co}$, and $8.3 \mathrm{pCi} / \mathrm{g}$ for ${ }^{137} \mathrm{Cs}$ (Table B-10). The highest concentrations in sump bottom sediment was $2.1 \mathrm{pCi} / \mathrm{g}$ of ${ }^{137} \mathrm{Cs}, 1.6 \mathrm{pCi} / \mathrm{g}$ of ${ }^{95} \mathrm{Zr}-\mathrm{Nb}$, and $0.5 \mathrm{pCi} / \mathrm{g}$ of. ${ }^{144} \mathrm{Ce}$ in the North Lagoon sump (N). The highest concentration of ${ }^{60} \mathrm{Co}$ was $0.2 \mathrm{pCi} / \mathrm{g}$ in the AGS-HFBR sump (O) (Table B-10).

In July 1968, the largest concentration of ${ }^{60} \mathrm{Co}$ in the fauna sampled was in tadpoles collected at station $\mathrm{M}$, with a concentration of $2.7 \mathrm{pCi} / \mathrm{g}$. The largest concentration for ${ }^{137} \mathrm{Cs}$ also was at station $\mathrm{M}$, with a concentration in frogs of $14 \mathrm{pCi} / \mathrm{g}$ (Table B-11).

The largest concentrations in stream vegetation for ${ }^{137} \mathrm{Cs}$ was at station $\mathrm{A}$, with a value of $1.6 \mathrm{pCi} / \mathrm{g}$, and for ${ }^{60} \mathrm{Co}$ at station $\mathrm{L}$, with a value of $1.4 \mathrm{pCi} / \mathrm{g}$. No radioactivity attributable to BNL operations was seen beyond sampling point B (Table B-11).

\subsection{3 $\underline{1969}$}

The November bottom sediment samples indicated that the largest concentrations occurred at station $\mathrm{M}$; the value for ${ }^{137} \mathrm{Cs}$ was $1.6 \mathrm{pCi} / \mathrm{g}$, and $0.89 \mathrm{pCi} / \mathrm{g}$ for ${ }^{60} \mathrm{Co}$ (Table $\mathrm{C}-10$ ). 


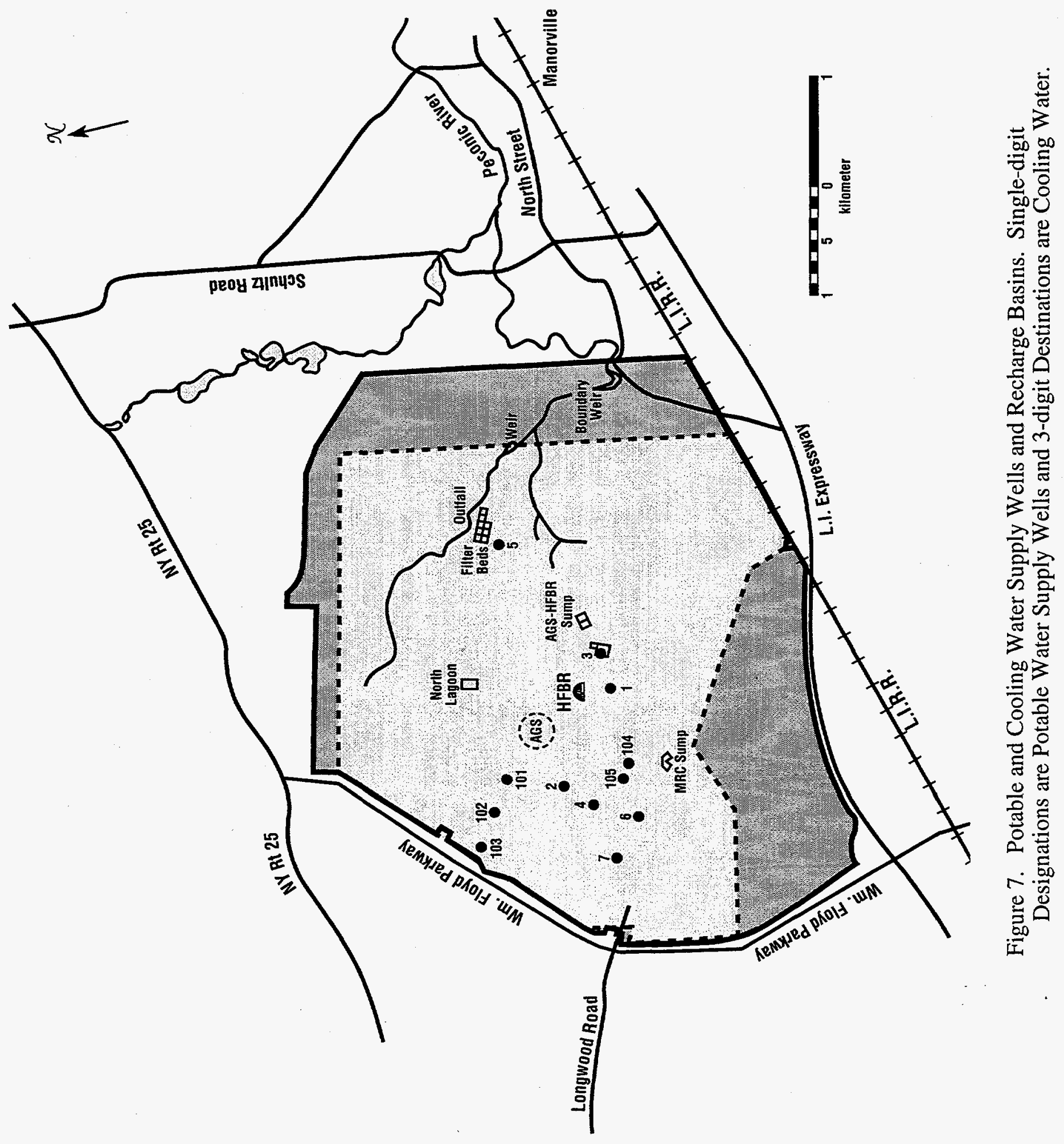


Vegetation samples were obtained in 1969 along the Peconic River between the Chlorinating Plant and Riverhead. The highest average concentration of ${ }^{60} \mathrm{Co}$ was at $6 \mathrm{pCi} / \mathrm{g}$, and ${ }^{137} \mathrm{Cs}$ at $1.1 \mathrm{pCi} / \mathrm{g}$ at sampling station $\mathrm{K}$ (Table $\mathrm{C}-11$ ).

For fish obtained in April at station Q, the new site perimeter, the largest concentration of ${ }^{60} \mathrm{Co}$ was $0.036 \mathrm{pCi} / \mathrm{g}$ and for ${ }^{137} \mathrm{Cs}, 1.6 \mathrm{pCi} / \mathrm{g}$. In August, the largest concentration of ${ }^{60} \mathrm{Co}$ in the fauna was $0.75 \mathrm{pCi} / \mathrm{g}$ in snails, and $1.8 \mathrm{pCi} / \mathrm{g}$ for ${ }^{137} \mathrm{Cs}$ in catfish (Table $\mathrm{C}-11$ ).

\subsubsection{0}

The River bottom sediment samples taken at station L indicated ${ }^{60} \mathrm{Co}$ concentration of 23 $\mathrm{pCi} / \mathrm{g}$ and ${ }^{137} \mathrm{Cs}$ concentration of $8 \mathrm{pCi} / \mathrm{gm}$ (Table D-10).

Cobalt-60 and ${ }^{137} \mathrm{Cs}$ concentrations (above fallout backgrounds) in vegetation at sampling station $\mathrm{M}$ were $2.3 \mathrm{pCi} / \mathrm{g}$ for ${ }^{60} \mathrm{Co}$ and $4.3 \mathrm{pCi} / \mathrm{g}$ for ${ }^{137} \mathrm{Cs}$ (Table D-11).

\subsection{BNL Potable and Cooling Water Supply Wells}

BNL's potable and cooling water supply wells were sampled routinely. These wells are screened at depths from 100 to 150 feet below land surface (50 to 100 feet into the water table). Their locations are given in Figure 7. Drinking-water supplies are designated with single digits, and cooling-water supplies with three digits.

\subsubsection{7}

In 1967, the largest yearly average gross beta concentration in the supply wells was less than $3.6 \mathrm{pCi} / \ell$ (Table A-10), about $0.12 \%$ of the applicable radiation protection guide. For tritiated water, the largest annual average concentration was about $1,200 \mathrm{pCi} / \ell$ (Table A-10) or less than $.04 \%$ of the applicable radiation protection guide.

\subsubsection{8}

In 1968, the largest yearly average gross beta concentration in the supply wells was $4.1 \mathrm{pCi} / \ell$ (Table B-12), which was $0.14 \%$ of the radiation protection guide. For tritiated water, the largest annual average concentration was less than $1,700 \mathrm{pCi} / \ell$ (Table B-12), or $0.06 \%$ of the applicable radiation protection guide. 


\subsection{3 $\underline{1969}$}

In 1969, the highest yearly average gross beta concentration in the supply wells was $2.3 \mathrm{pCi} / \ell$ (Table $\mathrm{C}-12$ ), which was $.08 \%$ of the applicable radiation protection guide. The maximum annual tritiated water concentration was about $1,200 \mathrm{pCi} / \ell$ (Table C-12), less than $.04 \%$ of the applicable radiation protection guide.

\subsection{4 $\underline{1970}$}

In 1970 , the largest yearly gross beta concentration in the supply wells was less than $3.9 \mathrm{pCi} /$ (Table D-12), which was about $0.13 \%$ of the applicable radiation protection guide. For tritiated water, the largest annual concentration was about $1,100 \mathrm{pCi} / \ell$ (Table D-12), less than $.037 \%$ of the applicable radiation protection guide.

\subsection{Recharge Basins (Sumps)}

About $4 \times 10^{6}$ gallons per day of the water withdrawn from the aquifer is returned to three recharge basins designated N (North Lagoon), O (AGS-HFBR sump), and P (MRC sump), as shown on Figure 7.

\subsubsection{7}

Data for 1967 could not be located.

\subsubsection{8}

For 1968, the highest annual average gross beta concentration was $\sim 4.5 \mathrm{pCi} / \ell$ (Table B-13) or $0.1 \%$ of the applicable radiation protection guide and the largest annual tritiated water concentration was less than $1,100 \mathrm{pCi} / \ell$; less than $.037 \%$ of the radiation protection guide (Table B-13).

\subsubsection{9}

For 1969, the highest annual average gross beta concentration was $\sim 8.6 \mathrm{pCi} / \ell$ (Table $\mathrm{C}-13$ ) or $\sim 0.3 \%$ of the applicable radiation protection guide. The tritiated water concentrations again were less than $1,100 \mathrm{pCi} / \ell$; less than $.037 \%$ of the radiation protection guide (Table $\mathrm{C}-13$ ). 


\subsubsection{0}

For 1970 , the highest annual average gross beta concentration was $\sim 8.6 \mathrm{pCi} / \ell$ (Table D-13) or $~ 0.29 \%$ of the applicable radiation protection guide. The tritiated water concentrations again were less than $1,100 \mathrm{pCi} / \mathrm{l}$; less than $.037 \%$ of the radiation protection guide (Table D-13).

\subsection{Ground Water Monitoring}

Ground water down gradient of a Waste Management area well which was accidentally contaminated in 1960 was monitored during this period. The data on this incident are contained in previously reported documentation. ${ }^{17}$

In 1969 , the storm drain for the outside decontamination pad at Building 650 , which was not in active use, was found to be discharging to an open sump rather than into the sanitary waste system. Several sampling wells were subsequently installed, and the resulting data are discussed in previously reported documentation. ${ }^{17}$ 


\section{MILK SAMPLING}

In 1968 and 1969, monthly milk samples were obtained from the three active Suffolk County dairy farms located $6 \mathrm{~km}$ southwest, $10 \mathrm{~km}$ southeast, and $15 \mathrm{~km}$ northwest of the site.

The milk data show that the occurrences of ${ }^{131}$ I in the milk follows Chinese weapons tests quite closely, while ${ }^{137} \mathrm{Cs}$, which persists for longer times both in the atmosphere and in the food chain, occurs in the milk later and is more evenly distributed in time.

In both cases, farming practices such as fertilization frequency, crop rotation, and whether the cows are given stored feed or are in pastures, have an effect on the uptake of radionuclides and their subsequent appearance in milk.

\section{$5.1 \quad \underline{1967}$}

Data for 1967 could not be located.

\section{$5.2 \quad \underline{1968}$}

In 1968, monthly milk samples were obtained from the three active Suffolk County dairy farms located $8 \mathrm{~km}$ southwest, $10 \mathrm{~km}$ southeast, and $15 \mathrm{~km}$ northwest of the site. The average value in milk was $1.8 \mathrm{pCi} / \ell$ of ${ }^{131} \mathrm{I}$, and $11 \mathrm{pCi} / \ell$ of ${ }^{137} \mathrm{Cs}$. The highest value for ${ }^{131} \mathrm{I}$ of $5 \mathrm{pCi} / \ell$ was seen in January, and the highest ${ }^{137} \mathrm{Cs}$ value of $20 \mathrm{pCi} / \mathrm{l}$ in August (Table B-14). The elevated iodine values seen in January reflect the Chinese weapons test of December 24, 1967, while the cesium values reflect deposition throughout the year from the worldwide distribution of the fallout from this test.

The unusual results of 29 to $42 \mathrm{pCi} / \ell$ of ${ }^{65} \mathrm{Zn}$ in August and October reflect a realization that ${ }^{65} \mathrm{Zn}$ was an unexpected addition to the radionuclides in the fallout from the Chinese weapons test of December $1967 .^{18}$

\section{$5.3 \quad \underline{1969}$}

In 1969, monthly milk samples were obtained from the three active Suffolk County dairy farms located $8 \mathrm{~km}$ southwest, $10 \mathrm{~km}$ southeast, and $15 \mathrm{~km}$ northwest of the site. The average value in milk was $\sim 3 \mathrm{pCi} / \ell$ of ${ }^{131} \mathrm{I}$ and $\sim 15 \mathrm{pCi} / \ell$ of ${ }^{137} \mathrm{Cs}$. The highest value for ${ }^{131} \mathrm{I}$ of $9 \mathrm{pCi} / \ell$ was seen in November 1969 , shortly after the Chinese atomic nuclear weapons test of September 29. The highest value for ${ }^{137} \mathrm{Cs}$ was $28 \mathrm{pCi} / \ell$ seen in June (Table C-14).

The results of the 1969 milk samples are particularly instructive in that the BGRR operations had ceased in June of 1969. The September 29 Chinese weapons test, therefore, can be considered the source of the ${ }^{131} \mathrm{I}$ and ${ }^{65} \mathrm{Zn}$ found in these samples. 


\section{$5.4 \quad \underline{1970}$}

In 1970, only two dairies were sampled, one located $8 \mathrm{~km}$ southwest and the other $10 \mathrm{~km}$ southeast of the site (Table D-14). The annual average ${ }^{131} \mathrm{I}$ concentration in milk was $1.6 \mathrm{pCi} /$. For ${ }^{137} \mathrm{Cs}$, the average value was $26 \mathrm{pCi} / \ell$ and the maximum value $38 \mathrm{pCi} / \ell$ occurred in July and August. The averaged tritium concentration was $<1,000 \mathrm{pCi} / \ell$. 


\section{GRASS, VEGETATION, AND SOIL SAMPLING}

Grass, vegetation, and soil samples were obtained from five farms at various compass points and at distances from 3 to $15 \mathrm{~km}$ from the site. The results of the grass and vegetation samples taken in 1968, 1969, and 1970 are given in Tables B-15, C-15, and D-15. The results for soil sampling are given in Tables B-16, C-16, and D-16.

The data for 1967 could not be located. However, there is a study of radioactive ${ }^{65} \mathrm{Zn}$ found in corn mentioned in the August Health Physics and Safety Summary. That study suggested that "trace" concentrations found in corn at a farm 6 kilometers northeast of BNL were in reasonable agreement with those expected based on the average concentrations of ${ }^{65} \mathrm{Zn}$ in the BGRR-HFBR stack effluents.

However, the data for 1968,1969 , and 1970 given in the tables show that there is no significant difference between the samples obtained from farms generally upwind of BNL from those generally downwind from the site. Once again, the consistency of the results between times when the BGRR was operating and after it ceased operation, and the report of ${ }^{65} \mathrm{Zn}$ resulting from the Chinese weapons tests, ${ }^{18}$ support the conclusion that there was no measurable deposition from BNL operations. 


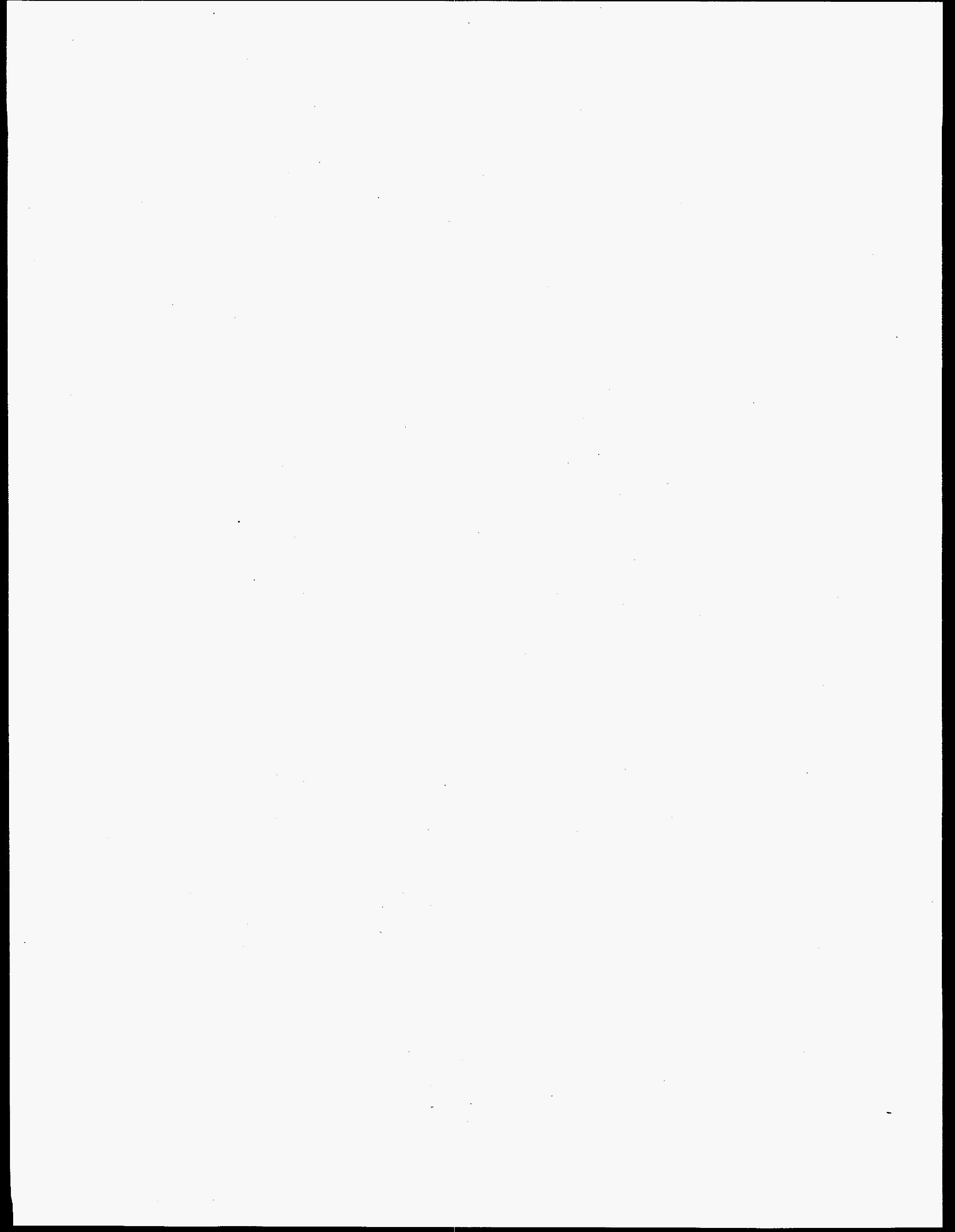




\section{REFERENCES}

1. A.P. Hull, 1962 Environmental Radiation Levels at Brookhaven National Laboratory, BNL Report 807 (T-310), May 1963.

2. A.P. Hull, 1963 Environmental Radiation Levels at Brookhaven National Laboratory, BNL Report 915 (T-376), November 1964.

3. A.P. Hull, 1964 Environmental Radiation Levels at Brookhaven National Laboratory, BNL Report 50001 (T-427), June 1966.

4. A.P. Hull, 1965 Environmental Monitoring Radiation Levels at Brookhaven National Laboratory, BNL Report 50093 (T-483), September 1967.

5. A.P. Hull and J.T. Gilmartin, 1966 Environmental Monitoring Radiation Levels at Brookhaven National Laboratory, BNL Report 50196 (T-552), September 1969.

6. A.P. Hull to F.W. Cowan, Monthly Reports from Environmental Monitoring Group Leader to the Head of the Health Physics Division, Brookhaven National Laboratory, covering the period January-December 1968; January to September 1969; and January to December 1970.

7. Brookhaven National Laboratory, Health Physics Summary Reports covering the period January-December 1967; January to December 1968; January to December 1969; and January to December 1970.

8. M.A. Warren, W. deLaguna, and N.J. Lusczynski, Hydrology of Brookhaven National Laboratory and Vicinity, Geological Survey Bulletin 1156-C (1968).

9. D.B. Clearlock and A.F. Reisenauer, Sitewide Ground Water Flow Studies for Brookhaven National Laboratory, Pacific Northwest Laboratory Informal Report, December 1971.

10. U.S. Atomic Energy Commission, USAEC Manual Chapter 0524 Standards for Radiation Protection, 1968.

11. J.B.H. Kuper and R.L. Chase, a Monitor for Low-intensity Gamma Rays, Rev. Sci. Instr. $21,356-9(1950)$.

12. U.S. Atomic Energy Commission, Standards for Radiation Protection, U.S. AEC Manual, Chapter 0524, Appendix A, Table II, Guide for Uncontrolled Areas (1968).

13. C.W. Sill and J.K. Flygore, Jr., Iodine Monitoring at the National Reactor Testing Station, Health Phys. 2, 261-8 (1960).

14. A.P. Hull, J.T. Gilmartin, and M.E. Smith, The Evaluation of Fission Product and Activation Isotopes in a Reactor Stack Effluent and in the Nearby Environment, BNL Report 12169, 1966. 
15. A.P. Hull, J.T. Gilmartin, and M.E. Smith, The Evaluation of Fission Product and Activation Isotopes in a Reactor Stack Effluent and in the Nearby Environment, BNL Report 12169, 1966.

16. A.P. Hull and J.A. Ash, 1974 Environmental Monitoring Report, BNL Report 19977, 1974.

17. SAIC, Brookhaven National Laboratory, Site Baseline Report, Volume 1, 1992.

18. W. Kolb, Zinc-65 in Ground-level Air: after the 1967 Chinese Nuclear Tests, Nature, Vol. 220, p. 364 (1968). 
APPENDIX A

\section{TABLES}


Table A-1. 1967 Background and Source Radiation Levels at the Laboratory Perimeter (mR/week)

\begin{tabular}{|c|c|c|c|c|c|c|c|c|c|c|c|c|c|c|}
\hline \multirow[t]{3}{*}{ Station: } & \multicolumn{2}{|l|}{ P-2 } & \multicolumn{2}{|c|}{ P-4 } & \multicolumn{2}{|c|}{ P-7 } & \multicolumn{3}{|c|}{ P-9 } & \multicolumn{3}{|c|}{ S-13 } & \multicolumn{2}{|l|}{$0-6$} \\
\hline & \multicolumn{2}{|c|}{ Northwest Perimeter } & \multicolumn{2}{|c|}{ Southwest Perimeter } & \multicolumn{2}{|c|}{ Southeast Perimeter } & \multicolumn{3}{|c|}{ Northeast Perimeter } & \multicolumn{3}{|c|}{ On site } & \multicolumn{2}{|c|}{ Off site } \\
\hline & Background & ${ }^{41} \mathrm{Ar}$ & Background & ${ }^{41} \mathrm{Ar}$ & Background & ${ }^{41} \mathrm{Ar}$ & Background & ${ }^{41} \mathrm{Ar}$ & $\begin{array}{l}\text { Ecology } \\
\text { Source }\end{array}$ & Background & ${ }^{41} \mathrm{Ar}$ & $\begin{array}{l}\text { Ecology } \\
\text { Source }\end{array}$ & Background & ${ }^{41} \mathrm{Ar}$ \\
\hline January & 1.9 & 0.04 & 2.1 & 0.28 & 2.0 & 0.52 & 2.3 & 0.52 & 1.2 & 2.2 & 0.84 & 0.76 & 1.9 & 0.01 \\
\hline February & 1.9 & 0.04 & 1.7 & 0.10 & 1.8 & 0.24 & 1.8 & 0.53 & 1.2 & 1.9 & 0.86 & 0.62 & 1.6 & 0.01 \\
\hline March & 1.7 & 0.09 & 1.6 & 0.32 & 1.7 & 0.25 & 1.6 & 0.40 & 1.1 & 1.7 & 0.86 & 0.68 & 1.5 & 0.01 \\
\hline April & 1.9 & 0.18 & 1.7 & 0.14 & 1.8 & 0.16 & 1.8 & 0.36 & 1.4 & 1.8 & 0.59 & 0.80 & 1.7 & 0.04 \\
\hline May & 1.8 & 0.29 & 1.7 & 0.04 & 1.7 & 0.45 & 1.7 & 0.70 & 1.6 & 1.7 & 1.4 & 0.87 & 1.7 & 0.04 \\
\hline June & 1.8 & 0.22 & 1.7 & 0.09 & 1.6 & 0.04 & 1.7 & 1.4 & 1.7 & 1.7 & 2.4 & 0.94 & 1.6 & 0.04 \\
\hline July & 1.9 & 0.30 & 1.9 & 0.49 & 1.8 & 0.15 & 1.8 & 0.52 & 2.0 & 1.9 & 0.76 & 1.2 & 1.7 & 0.04 \\
\hline August & 2.0 & 0.14 & 2.0 & 0.09 & 1.8 & 0.07 & 1.9 & 0.44 & 2.0 & 1.9 & 1.2 & 1.2 & 1.7 & 0.00 \\
\hline September & 2.0 & 0.14 & 1.9 & 0.25 & 1.8 & 0.13 & 1.8 & 0.13 & 1.9 & 1.9 & 0.28 & 1.1 & 1.7 & 0.02 \\
\hline October & 1.9 & 0.35 & 1.8 & 0.00 & 1.7 & 0.12 & 1.8 & 0.08 & 1.8 & 2.0 & 0.27 & 1.1 & 1.8 & 0.09 \\
\hline November & 1.9 & 0.02 & 1.9 & 0.14 & 1.7 & 0.31 & 1.7 & 0.12 & 1.3 & 2.0 & 0.25 & 0.94 & 1.8 & 0.00 \\
\hline December & 1.9 & $\underline{0.18}$ & $\underline{2.0}$ & $\underline{0.35}$ & $\underline{1.7}$ & $\underline{0.32}$ & $\underline{1.7}$ & $\underline{0.06}$ & 1.3 & $\underline{2.0}$ & $\underline{0.15}$ & $\underline{0.84}$ & $\underline{1.9}$ & $\underline{0.06}$ \\
\hline Average $\mathrm{mR} /$ week & 1.9 & 0.17 & 1.8 & 0.19 & 1.8 & 0.23 & 1.8 & 0.44 & 1.5 & 1.9 & 0.82 & 0.92 & 1.7 & 0.03 \\
\hline Total mR/year & 99 & 8.8 & 94 & 9.9 & 94 & 12 & 94 & 23 & 78 & 99 & 43 & 48 & 88 & $<1.6$ \\
\hline
\end{tabular}


Table A-2. 1967 Monthly Average Gross Beta Concentrations, Air Particulate Filters (pCi/m³)

\begin{tabular}{|c|c|c|c|c|c|c|c|c|c|c|c|}
\hline Month & $\begin{array}{c}\text { Gross } \\
\text { Beta } \\
\text { Conc. }\end{array}$ & Max & Min & ${ }^{7} \mathbf{B e}$ & ${ }^{65} \mathrm{Zn}$ & ${ }^{95} \mathrm{Zr}-\mathrm{Nb}$ & ${ }^{103} \mathbf{R u}$ & ${ }^{131} I$ & ${ }^{137} \mathrm{Cs}$ & ${ }^{140} \mathrm{Ba}-\mathrm{La}$ & ${ }^{144} \mathrm{Ce}$ \\
\hline January & 0.55 & & & & & & & & & & \\
\hline February & 0.28 & & & & & & & & & & \\
\hline March & 0.27 & & & & & & & & & & \\
\hline April & 0.23 & & & & & & & & & & \\
\hline May & 0.13 & & & & & & & & & & \\
\hline June & 0.097 & & & \multirow{3}{*}{\multicolumn{5}{|c|}{ Isotopic data not located }} & & & \\
\hline July & 0.055 & & & & & & & & & & \\
\hline August & 0.047 & & & & & & & & & & \\
\hline September & 0.079 & & & & & & & & & & \\
\hline October & 0.12 & & & & & & & & & & \\
\hline November & 0.056 & & & & & & & & & & \\
\hline December & $\underline{0.86}$ & & & & & & & & & & \\
\hline Yearly Average & 0.23 & & & & & & & & & & \\
\hline
\end{tabular}


Table A-3. 1967 Monthly Average Gross Beta Concentration and Total Gross Beta Activity in Precipitation

\begin{tabular}{|c|c|c|c|c|c|c|c|c|}
\hline \multirow[b]{2}{*}{ Month } & \multirow{2}{*}{$\begin{array}{l}\text { Amount } \\
\text { Inches }\end{array}$} & \multirow{2}{*}{$\begin{array}{c}\text { Gross } \\
\text { Beta } \\
\text { Conc. } \\
\text { pCi/l } \\
\end{array}$} & \multirow{2}{*}{$\begin{array}{c}\text { Gross } \\
\text { Beta } \\
\text { Activity } \\
\text { nCi/m } \\
\end{array}$} & \multicolumn{5}{|c|}{ Nuclide Activity (nCi $\left./ \mathrm{m}^{2}\right)$} \\
\hline & & & & ${ }^{7} \mathbf{B e}$ & ${ }^{89} \mathrm{Sr}$ & ${ }^{90} \mathrm{Sr} \quad{ }^{95} \mathrm{Zr}-\mathrm{Nb} \quad{ }^{103} \mathrm{Ru} \quad{ }^{131} \mathrm{I} \quad{ }^{137} \mathrm{Cs}$ & ${ }^{140} \mathrm{Ba}-\mathrm{La}{ }^{141} \mathrm{Ce}$ & ${ }^{144} \mathrm{Ce}$ \\
\hline January & 1.7 & $260^{\mathrm{a}}$ & $270^{\mathrm{a}}$ & & & & & \\
\hline February & 4.0 & 6.4 & 9.6 & & & & & \\
\hline March & 8.2 & 9.6 & 14 & & & & & \\
\hline April & 4.1 & 6.6 & 7.2 & & & & & \\
\hline May & 8.0 & 3.9 & 5.6 & & & & & \\
\hline $\begin{array}{l}\text { June } \\
\text { July }\end{array}$ & $\begin{array}{l}5.3 \\
6.0\end{array}$ & $\begin{array}{l}1.2 \\
2.2\end{array}$ & $\begin{array}{l}1.5 \\
2.5\end{array}$ & & & Isotopic data not located & & \\
\hline August & 5.4 & 0.82 & 1.2 & & & & & \\
\hline September & 2.2 & 0.37 & 0.6 & & & & & \\
\hline October & 2.1 & 0.51 & 0.93 & & & & & \\
\hline November & 4.0 & 3.0 & 2.4 & & & & & \\
\hline December & 7.6 & $\underline{1,600^{\mathrm{a}}}$ & $\underline{1,800^{2}}$ & & & & & \\
\hline Total & 58.6 & & 2,100 & & & & & \\
\hline Weighted Average $^{\mathrm{b}}$ & & 210 & & & & & & \\
\hline
\end{tabular}


Table A-4. 1967 BGRR-HFBR Stack Emission

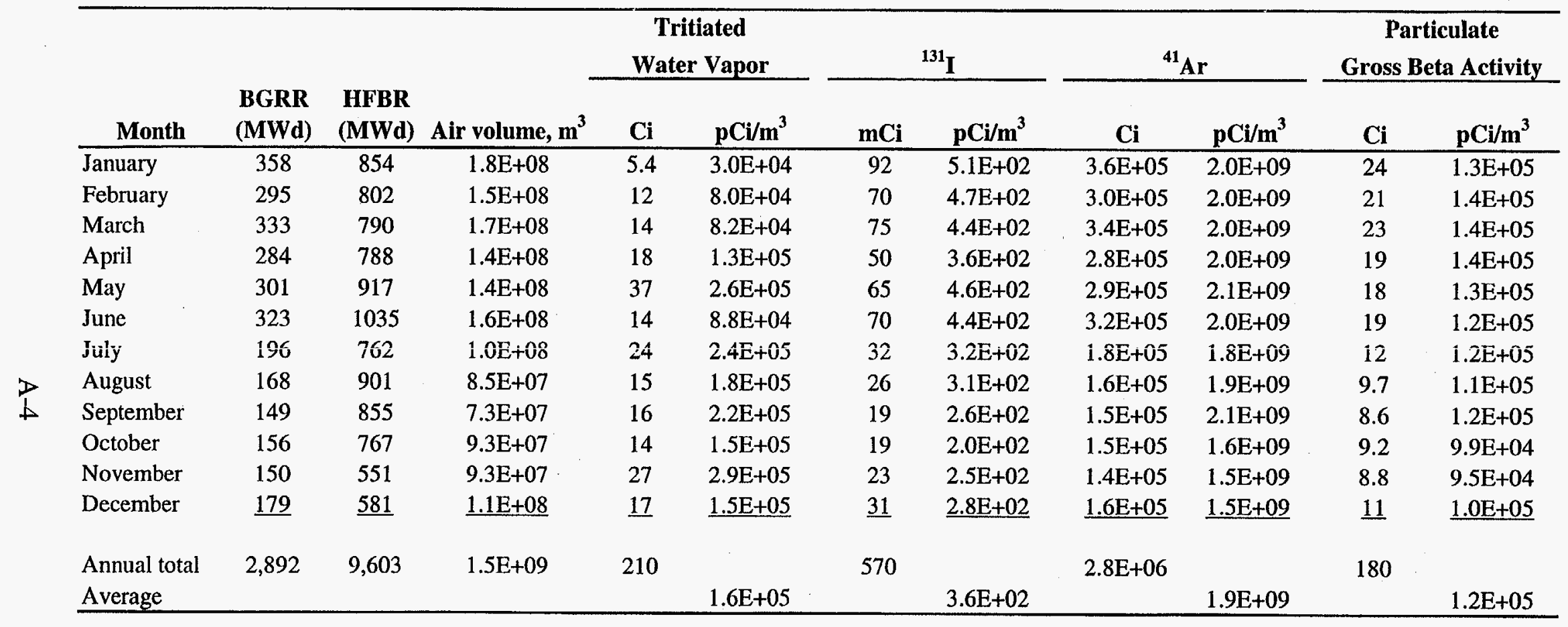


Table A-5. 1967 Imhoff/Clarifier Tank. Flow, Gross Beta, Tritiated Water, ${ }^{90} \mathrm{Sr}$, and ${ }^{137} \mathrm{Cs}$ Amounts and Concentrations

\begin{tabular}{|c|c|c|c|c|c|c|c|c|c|}
\hline \multirow[b]{2}{*}{ Month } & \multirow[b]{2}{*}{$\begin{array}{c}\text { Flow } \\
10^{9} 1\end{array}$} & \multicolumn{2}{|c|}{ Gross Beta $^{a}$} & \multicolumn{2}{|c|}{ Tritiated Water } & \multicolumn{2}{|c|}{${ }^{90} \mathrm{Sr}^{\mathrm{b}}$} & \multicolumn{2}{|c|}{${ }^{137} \mathrm{Cs}^{\mathrm{b}}$} \\
\hline & & $\begin{array}{l}\text { Conc. } \\
\mathrm{pCi} / \mathrm{l}\end{array}$ & $\begin{array}{c}\text { Amount } \\
\text { mCi }\end{array}$ & $\begin{array}{l}\text { Conc. } \\
\mathrm{pCi} / 1\end{array}$ & $\begin{array}{c}\text { Amount } \\
\text { mCi }\end{array}$ & $\begin{array}{l}\text { Conc. } \\
\mathrm{pCi} / 1\end{array}$ & $\begin{array}{c}\text { Amount } \\
\text { mCi }\end{array}$ & $\begin{array}{l}\text { Conc. } \\
\mathrm{pCi} / \mathrm{l}\end{array}$ & $\begin{array}{c}\text { Amount } \\
\text { mCi }\end{array}$ \\
\hline January & 0.087 & 23 & 2.0 & 18,000 & 1,600 & 1.2 & 0.10 & 2.3 & 0.20 \\
\hline February & 0.083 & 25 & 2.1 & 13,000 & 1,100 & 1.3 & 0.11 & 2.5 & 0.21 \\
\hline March & 0.089 & $490^{d}$ & 44 & 6,200 & 550 & 1.4 & 0.12 & 2.8 & 0.25 \\
\hline April & 0.13 & 52 & 6.8 & 7,100 & 920 & 1.0 & 0.13 & 2.0 & 0.26 \\
\hline July & 0.13 & 41 & 5.2 & 3,200 & 420 & 2.1 & 0.27 & 4.1 & 0.52 \\
\hline August & 0.12 & 23 & 2.8 & 4,200 & 500 & 1.2 & 0.15 & 2.3 & 0.28 \\
\hline September & 0.11 & 15 & 1.6 & 3,100 & 340 & 0.8 & 0.09 & 1.5 & 0.16 \\
\hline October & 0.1 & 48 & 4.9 & 7,300 & 730 & 2.4 & 0.25 & 4.8 & 0.49 \\
\hline November & 0.089 & 24 & 2.1 & 9,000 & 800 & 1.2 & 0.11 & 2.4 & 0.21 \\
\hline
\end{tabular}

${ }^{a}$ Includes gamma-only emitters; does not include tritiated water.

${ }^{\text {b }}{ }^{90} \mathrm{Sr}$ and ${ }^{137} \mathrm{Cs}$ reconstructed based on the 1966 ratio to gross beta $\left({ }^{90} \mathrm{Sr}=5 \%,{ }^{137} \mathrm{Cs}=10 \%\right)$, except for the unusual gross beta concentration events of March and April, which were known to be Tungsten-185 (see section 4.1.1). For these two months, the ${ }^{90} \mathrm{Sr}$ and ${ }^{137} \mathrm{Cs}$ values were based on those in the preceding and following months.

${ }^{c}$ Weighted average concentration $=$ total amount $(\mathrm{mCi}) /$ total flow $\left(10^{9} 1\right)$.

${ }^{d}$ See section 4.1.1. 
Table A-6. 1967 Chlorinating Plant. Flow, Gross Beta, Tritiated Water, ${ }^{90} \mathrm{Sr}$, and ${ }^{137} \mathrm{Cs}$ Amounts and Concentrations

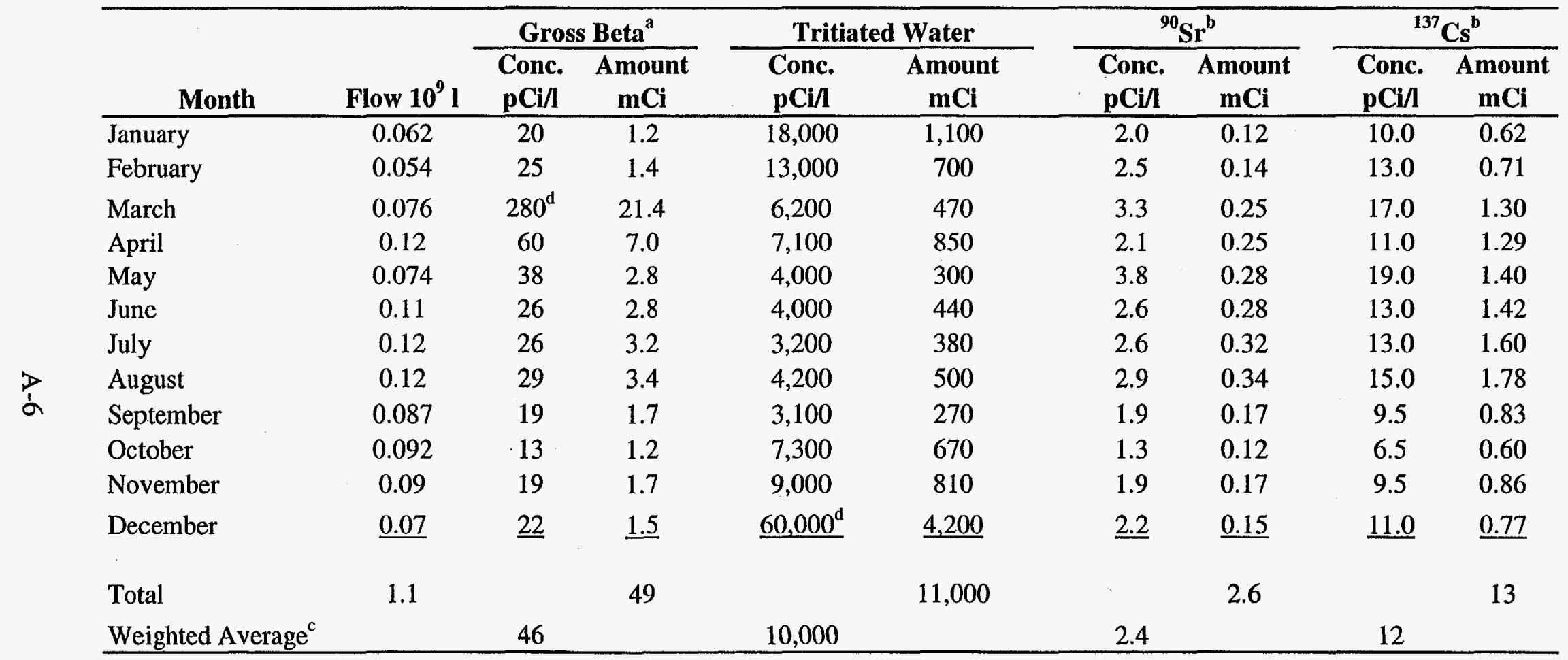

a Includes gamma-only emitters; does not include tritiated water.

${ }^{\text {b }}{ }^{90} \mathrm{Sr}$ and ${ }^{137} \mathrm{Cs}$ reconstructed based on average of $1966-1968$ ratio to gross beta $\left({ }^{90} \mathrm{Sr} 10 \%,{ }^{137} \mathrm{Cs} 50 \%\right)$, except for the unusual gross beta concentration events of March and April, which were known to be Tungsten-185 (see section 4.1.1).

For these two months, the ${ }^{90} \mathrm{Sr}$ and ${ }^{137} \mathrm{Cs}$ values were based on those in the preceding and following months.

${ }^{\mathrm{c}}$ Weighted average concentration $=$ total amount $(\mathrm{mCi}) /$ total flow $\left(10^{9} \mathrm{l}\right)$.

${ }^{\mathrm{d}}$ See section 4.1.1. 
Table A-7. 1967 "M" (Former Perimeter). Flow, Gross Beta, Tritiated Water, ${ }^{90} \mathrm{Sr}$, and ${ }^{137} \mathrm{Cs}$ Amounts and Concentrations

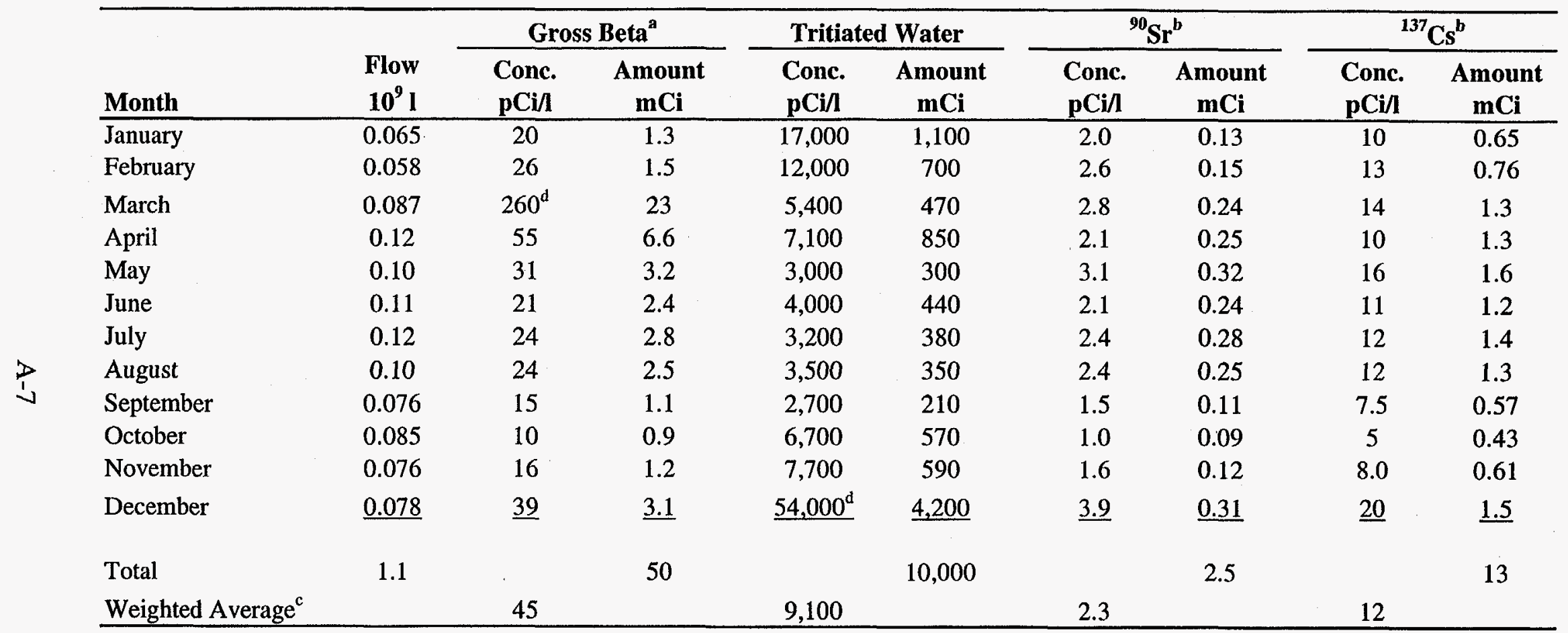

${ }^{a}$ Includes gamma-only emitters; does not include tritiated water.

${ }^{b}{ }^{90} \mathrm{Sr}$ and ${ }^{137} \mathrm{Cs}$ reconstructed based on average of $1966-1968$ ratio to gross beta $\left({ }^{90} \mathrm{Sr} 10 \%,{ }^{137} \mathrm{Cs} 50 \%\right)$ except for the unusual gross beta concentration events of March and April, which were known to be Tungsten-185 (see section 4.1.1).

For these two months, the ${ }^{90} \mathrm{Sr}$ and ${ }^{137} \mathrm{Cs}$ values were based on those in the preceding and following months.

${ }^{\mathrm{c}}$ Weighted average concentration $=$ total amount $(\mathrm{mCi}) /$ total flow $\left(10^{9} \mathrm{l}\right)$.

${ }^{\mathrm{d}}$ See section 4.1.1. 
Table A-8. 1967 "Q" (Current Perimeter). ${ }^{a}$ Flow, Gross Beta, Tritiated Water, ${ }^{90}$ Sr, and ${ }^{137}$ Cs Amounts and Concentrations

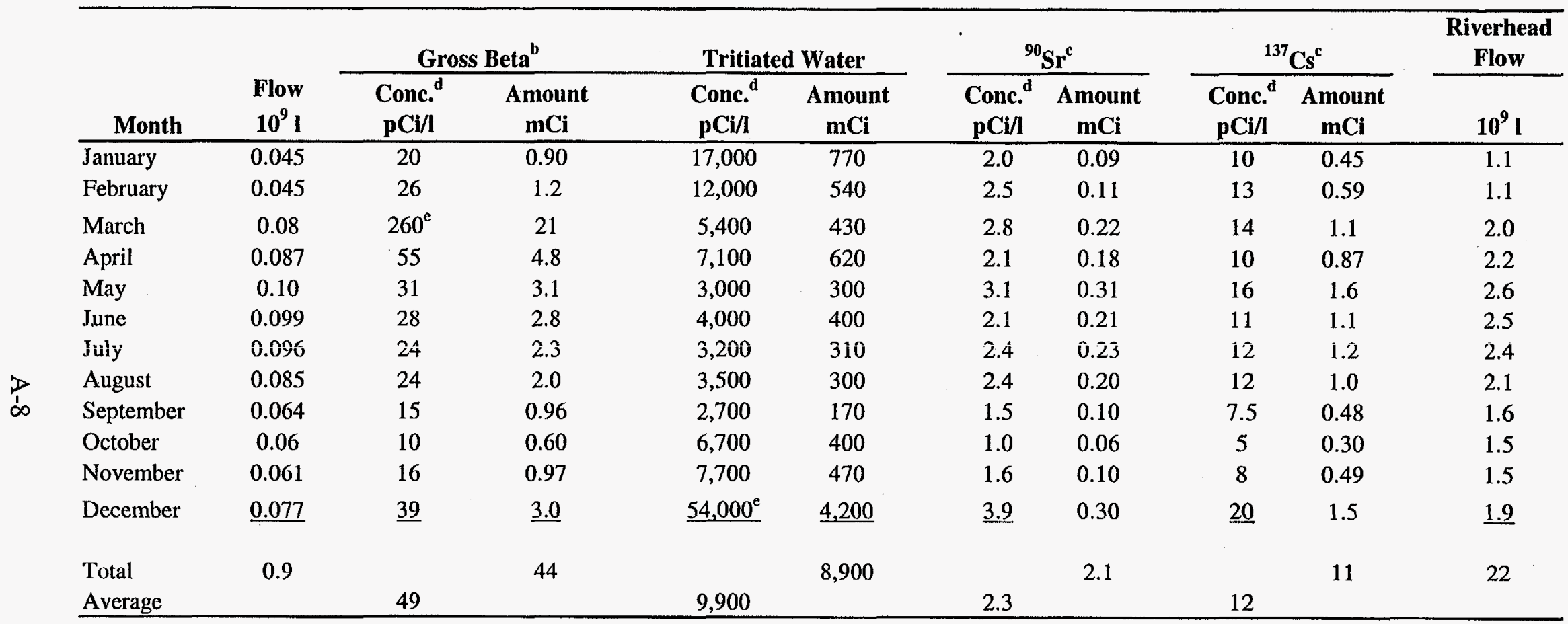

${ }^{a}$ Flow inferred from 1/25 of USGS measured flow at Riverhead. The weir not installed at station "Q" until 1969.

${ }^{\mathrm{b}}$ Includes gamma-only emitters; does not include tritiated water.

${ }^{c}{ }^{90} \mathrm{Sr}$ and ${ }^{137} \mathrm{Cs}$ reconstructed based on the 1966 ratio to gross beta $\left({ }^{90} \mathrm{Sr}=5 \%,{ }^{137} \mathrm{Cs}=10 \%\right)$, except for the unusual gross beta concentration events of March and April, which were known to be Tungsten-185 (see section 4.1.1). For these two months, the ${ }^{90} \mathrm{Sr}$ and ${ }^{137} \mathrm{Cs}$ values were based on those in the preceding and following months.

'Concentrations measured at "M" assumed for "Q."

${ }^{\mathrm{e}}$ See section 4.1.1. 
Table A-9. 1967 Monthly Downstream and Control Location Water Grab Samples. Gross Beta and Tritiated Water Concentration

\begin{tabular}{|c|c|c|c|c|c|c|c|c|c|c|c|c|c|}
\hline \multirow[b]{2}{*}{ Month } & \multicolumn{8}{|c|}{ Downstream Locations } & \multicolumn{5}{|c|}{ Control Locations } \\
\hline & $\mathbf{A}$ & B & $\mathrm{C}$ & D & $\mathbf{K}$ & $\mathbf{L}$ & $\mathbf{M}^{\mathbf{a}}$ & $\mathbf{Q}$ & $\mathbf{E}$ & $\mathbf{F}$ & $\mathbf{H}$ & I & $\mathbf{J}$ \\
\hline \multicolumn{14}{|c|}{ Gross Beta (pCi/l) } \\
\hline January & 15 & 7.1 & 6.9 & 14 & 19 & 20 & 22 & 18 & - & 330 & 9.7 & 99 & 4.9 \\
\hline February & 14 & 8.6 & 8.2 & 18 & 26 & 25 & 18 & 24 & 5.1 & 16 & 3.4 & 22 & 7.0 \\
\hline March & 20 & 10 & 7.6 & 8.5 & 74 & 35 & 17 & 67 & 7.9 & 100 & 6.3 & 17 & 7.2 \\
\hline April & 16 & 13 & 11 & 7.5 & 58 & 39 & 50 & 47 & 7.4 & 23 & 4.2 & 18 & 8.1 \\
\hline May & 13 & 9.8 & 5.0 & 6.3 & 47 & 40 & 43 & 27 & 5.4 & - & 8.2 & 28 & 9.3 \\
\hline June & 21 & 14 & 7.6 & 4.4 & 35 & 36 & 23 & 48 & 3.6 & 27 & $<1.0$ & 15 & 6.5 \\
\hline July & 9.7 & 6.4 & 9.5 & 6.2 & 23 & 30 & 17 & 17 & 4.0 & 11 & 1 & 6.4 & 6.7 \\
\hline August & 1.6 & 1.7 & 4.3 & 2.7 & 32 & 27 & 33 & 33 & 2.2 & 6.2 & $<1.1$ & 7.7 & 4.1 \\
\hline September & 2.5 & 1.0 & 3.3 & 4.3 & 15 & 13 & 16 & 20 & - & 6.4 & 1.4 & 6.1 & 4.7 \\
\hline October & 4.1 & 2.1 & 3.7 & 5.5 & 24 & 20 & 28 & 24 & - & 5.2 & 1.8 & 8.3 & 4.9 \\
\hline November & 3.5 & 2.3 & 3.9 & 5.9 & 16 & 12 & 18 & 15 & - & 4.2 & 1.9 & 6 & 4.1 \\
\hline December & $\underline{3.6}$ & $\underline{3.7}$ & $\underline{2.1}$ & $\underline{2.7}$ & 12 & 14 & $\underline{22}$ & 14 & $=$ & $\underline{7.3}$ & 1.3 & $\underline{4.3}$ & $\underline{3.5}$ \\
\hline Yearly Average & 10 & 6.7 & 6.1 & 7.2 & 32 & 26 & 26 & 30 & 5.1 & 48 & $<28$ & 20 & 5.9 \\
\hline \multicolumn{14}{|c|}{ Tritiated Water (pCi/l) } \\
\hline January & $<1,000$ & $<1,000$ & $<1,000$ & $<1,000$ & 7,600 & 6,400 & 16,000 & 4,800 & - & 1,100 & - & $<1,000$ & $<1,000$ \\
\hline February & $<1,000$ & $<1,000$ & - & - & - & - & 16,000 & - & - & $<1,000$ & - & - & - \\
\hline March & $<1,000$ & $<1,000$ & 1,600 & $<1,000$ & 3,200 & 2,300 & 5,800 & 3,400 & $<1,000$ & 1,000 & $<1,000$ & $<1,000$ & 1,100 \\
\hline April & $<1,000$ & $<1,000$ & $<1,000$ & $<1,000$ & 3,000 & 2,600 & 2,600 & 2,900 & $<1,000$ & - & $<1,000$ & $<1,000$ & $<1,000$ \\
\hline May & 2,200 & $<1,000$ & 1,400 & $<1,000$ & 1,000 & $<1,000$ & - & 1,700 & 1,200 & $<1,000$ & $<1,000$ & $<1,000$ & $<1,000$ \\
\hline June & 4,100 & $<1,000$ & $<1,000$ & $<1,000$ & 6,400 & 6,000 & - & 4,100 & $<1,000$ & $<1,000$ & $<1,000$ & 1,400 & $<1,000$ \\
\hline July & $<1,000$ & $<1,000$ & $<1,000$ & $<1,000$ & 4,300 & 3,800 & - & 2,300 & $<1,000$ & $<1,000$ & $<1,000$ & $<1,000$ & $<1,000$ \\
\hline August & $<1,000$ & $<1,000$ & 2,400 & $<1,000$ & $<1,000$ & $<1,000$ & - & 2,100 & 1,800 & $<1,000$ & $<1,000$ & $<1,000$ & $<1,000$ \\
\hline September & $<1,000$ & $<1,000$ & $<1,000$ & $<1,000$ & 2,500 & 3,300 & - & 3,100 & - & $<1,000$ & $<1,000$ & 1,300 & $<1,000$ \\
\hline October & $<1,000$ & $<1,000$ & $<1,000$ & $<1,000$ & 7,200 & 7,600 & - & 8,400 & - & $<1,000$ & $<1,000$ & $<1,000$ & $<1,000$ \\
\hline November & $<1,000$ & $<1,200$ & 1,500 & $<1,200$ & 3,400 & 18,000 & - & 2,500 & - & $<1,200$ & 1,800 & $<1,200$ & 1,600 \\
\hline December & $\leq 1,000$ & $\leq 1,000$ & $\leq 1,000$ & $\leq 1,000$ & $\underline{7,200}$ & $\underline{12,000}$ & $=$ & $\underline{12,000}$ & $=$ & $=$ & $\leq 1,000$ & $\leq 1,000$ & $\leq 1,000$ \\
\hline Yearly Average & $<1,400$ & $<1,100$ & $<1,300$ & $<1,100$ & $<4,300$ & $<5,900$ & - & 4,300 & - & $<1,100$ & $<1,100$ & $<1,100$ & $<1,200$ \\
\hline
\end{tabular}

${ }^{a}$ Continuous sample

$<$ means that the value is less than or equal to the detection limit or a summation or average value in which one of the components was a $<$ value. 
Table A-10. 1967 Gross Beta and Tritiated Water Concentrations in Potable and Cooling Water Supply Wells

\begin{tabular}{|c|c|c|c|c|c|c|c|c|c|c|c|c|}
\hline Month & Well 1 & Well 2 & Well 3 & Well 4 & Well 5 & Well 6 & Well 7 & Well 101 & Well 102 & Well 103 & Well 104 & Well 105 \\
\hline \multicolumn{13}{|c|}{ Gross Beta $(\mathrm{pCi} / 1)$} \\
\hline January & $<1.0$ & $<1.0$ & $<0.9$ & $<1.0$ & 1.5 & 1.3 & $<1.0$ & 1.4 & 1.1 & $<1.0$ & - & 1.0 \\
\hline February & $<1.0$ & 2.1 & $<0.9$ & 1.4 & 2.9 & $<1.0$ & 1.4 & 4.8 & 3.0 & 2.4 & $<1.2$ & 1.4 \\
\hline March & $<1.0$ & $<0.9$ & $<0.9$ & 1.2 & 1.4 & 1.2 & 1.6 & 4.9 & $<0.6$ & 1.0 & - & 1.7 \\
\hline April & 1.3 & 1.3 & 1.1 & 1.2 & $<1.0$ & 1.3 & $<1.0$ & - & - & - & - & - \\
\hline May & $<1.0$ & 1.4 & 1.0 & 2.2 & $<0.9$ & $<0.9$ & 2.1 & $<0.9$ & 2.2 & 0.9 & 2.0 & $<0.9$ \\
\hline June & $<0.9$ & $<0.9$ & $<0.9$ & $<0.9$ & $<0.9$ & $<0.9$ & 1.6 & $<0.9$ & 1.0 & 1.3 & $<1.1$ & 1.1 \\
\hline July & $<0.7$ & $<0.6$ & $<0.6$ & 1.0 & $<0.7$ & $<0.5$ & $<0.6$ & $<0.4$ & $<0.5$ & $<0.6$ & $<0.6$ & 0.8 \\
\hline August & 1.7 & $<0.9$ & 1.4 & $<1.0$ & 2.4 & $<1.0$ & - & 14.1 & $<1.0$ & $<0.9$ & 1.1 & $<1.0$ \\
\hline September & $<0.9$ & 1.2 & $<0.9$ & 1.2 & 1.4 & - & 1.4 & 9.0 & - & 1.3 & 1.3 & 1.9 \\
\hline October & 1.7 & $<0.9$ & $<0.9$ & 1.7 & - & 1.3 & $<0.9$ & $<0.9$ & $<0.9$ & $<0.9$ & $<1.0$ & 1.4 \\
\hline November & $<0.9$ & - & 2.4 & 2.0 & $<0.9$ & 2.2 & 2.1 & 1.2 & 1.5 & 1.4 & 1.2 & $<1.0$ \\
\hline December & 1.3 & $\leq 1.0$ & $\underline{1.2}$ & $\underline{1.7}$ & $\underline{2.3}$ & $\leq 1.0$ & $\leq 1.0$ & $\leq i . \overline{0}$ & $\underline{\mathbf{1} .6}$ & $\underline{2.7}$ & $\underline{2.2}$ & $\underline{2.5}$ \\
\hline Yearly Average & $<1.1$ & $<1.1$ & $<1.1$ & $<1.4$ & $<1.5$ & $<1.1$ & $<1.3$ & $<3.6$ & $<1.3$ & $<1.3$ & $<1.3$ & $<1.3$ \\
\hline \multicolumn{13}{|c|}{ Tritiated Water $(\mathrm{pCi} / /)$} \\
\hline January & - & - & - & - & - & - & - & - & - & - & - & - \\
\hline February & - & - & - & - & - & - & - & - & - & - & - & - \\
\hline March & $<1,000$ & $<1,000$ & $<1,000$ & $<1,000$ & $<1,000$ & $<1,000$ & $<1,000$ & $<1,000$ & $<1,000$ & $<1,000$ & $<1,000$ & - \\
\hline April & $<1,000$ & $<1,000$ & $<1,000$ & $<1,000$ & $<1,000$ & $<1,000$ & $<1,000$ & - & - & $<1,000$ & - & - \\
\hline May & $<1,000$ & $<1,000$ & 1,300 & $<1,000$ & 1,700 & 1,100 & $<1,000$ & $<1,000$ & $<1,000$ & 1,600 & 1,600 & $<1,000$ \\
\hline June & 1,400 & $<1,000$ & $<1,000$ & 1,200 & $<1,000$ & 1,700 & $<1,000$ & $<1,000$ & $<1,000$ & $<1,000$ & $<1,000$ & $<1,000$ \\
\hline July & $<1,000$ & $<1,000$ & $<1,000$ & $<1,000$ & $<1,000$ & $<1,000$ & $<1,000$ & $<1,000$ & $<1,000$ & $<1,000$ & $<1,000$ & $<1,000$ \\
\hline August & 1,200 & $<1,000$ & $<1,000$ & $<1,000$ & $<1,000$ & $<1,000$ & $<1,100$ & $<1,000$ & $<1,000$ & $<1,000$ & $<1,000$ & $<1,000$ \\
\hline September & $<1,100$ & $<1,000$ & $<1,000$ & 1,100 & $<1,000$ & $<1,000$ & $<1,000$ & $<1,000$ & - & $<1,100$ & $<1,200$ & $<1,100$ \\
\hline October & 1,400 & 1,400 & $<1,000$ & $<1,000$ & - & - & 1,400 & $<1,000$ & 1,400 & $<1,000$ & 1,200 & 1,200 \\
\hline November & 1,700 & - & $<1,000$ & $<1,000$ & $<1,000$ & 1,300 & 1,300 & 1,500 & 1,900 & $<1,400$ & $<1,000$ & $<1,400$ \\
\hline December & $\leq 1,000$ & $\underline{2,200}$ & $\underline{1,700}$ & $\underline{1,500}$ & $\leq 1,000$ & $\leq 1,000$ & $\leq 1,000$ & $\leq 1,000$ & $\leq 1,000$ & $\underline{1,500}$ & $\leq 1,000$ & $\leq 1,000$ \\
\hline Yearly Average & $<1,200$ & $<1,200$ & $\leq 1,100$ & $<1,100$ & $<1,100$ & $<1,100$ & $\leq 1,200$ & $<1,100$ & $<1,200$ & $<1,200$ & $<1,200$ & $<1,100$ \\
\hline
\end{tabular}

$<$ means that the value is less than or equal to the detection limit or a summation or average value in which one of the components was a $<$ value. 
APPENDIX B

1968 TABLES 
Table B-1. 1968 Background and Source Radiation Levels at the Laboratory Perimeter (mR/week)

\begin{tabular}{|c|c|c|c|c|c|c|c|c|c|c|c|c|c|c|}
\hline \multirow[t]{3}{*}{ Station: } & \multicolumn{2}{|c|}{ P-2 } & \multicolumn{2}{|c|}{$\mathbf{P}-4$} & \multicolumn{2}{|l|}{ P-7 } & \multicolumn{3}{|c|}{ P-9 } & \multicolumn{3}{|c|}{ S-13 } & \multicolumn{2}{|l|}{0.6} \\
\hline & \multicolumn{2}{|c|}{ Northwest Perimeter } & \multicolumn{2}{|c|}{ Southwest Perimeter } & \multicolumn{2}{|c|}{ Southeast Perimeter } & \multicolumn{3}{|c|}{ Northeast Perimeter } & \multicolumn{3}{|c|}{ On-site } & \multicolumn{2}{|c|}{ Off-site } \\
\hline & Background & ${ }^{41} \mathrm{Ar}$ & Background & ${ }^{41} \mathrm{Ar}$ & Background & ${ }^{41} \mathrm{Ar}$ & Background & ${ }^{4 t} \mathrm{Ar}$ & $\begin{array}{c}\text { Ecology } \\
\text { Source }\end{array}$ & Background & ${ }^{41} \mathrm{Ar}$ & $\begin{array}{c}\text { Ecology } \\
\text { Source }\end{array}$ & Background & ${ }^{41} \mathrm{Ar}$ \\
\hline January & 2.1 & 0.04 & 2.8 & 0.06 & 2.3 & 0.35 & 2.0 & 0.26 & 1.2 & 2.6 & 0.47 & 0.72 & 2.3 & 0.01 \\
\hline February & 1.7 & 0.01 & 1.9 & 0.12 & 1.8 & 0.34 & 1.7 & 0.04 & 1.2 & 1.9 & 0.11 & 0.73 & 1.7. & 0.01 \\
\hline March & 1.6 & 0.02 & 1.7 & 0.11 & 1.7 & 0.17 & 1.6 & 0.26 & 1.3 & 1.7 & 0.5 & 0.81 & 1.6 & 0.0 \\
\hline April & 1.7 & 0.23 & 1.9 & 0.06 & 1.9 & 0.09 & 1.7 & 0.27 & 1.5 & 1.8 & 0.54 & 0.92 & 1.6 & 0.04 \\
\hline May & 1.7 & 0.05 & 1.9 & 0.16 & 1.9 & 0.07 & 1.7 & 0.54 & 1.6 & 1.8 & 0.87 & 0.98 & 1.6 & 0.01 \\
\hline June & 1.7 & 0.1 & 1.9 & 0.02 & 1.8 & 0.15 & 1.7 & 0.45 & 1.8 & 1.7 & 0.65 & 1.1 & 1.6 & 0.02 \\
\hline July & 1.7 & 0.0 & 1.9 & 0.0 & 1.7 & 0.0 & 1.6 & 0.0 & 1.9 & 1.8 & 0.0 & 1.1 & 1.6 & 0.0 \\
\hline August & 1.9 & 0.0 & 2.1 & 0.0 & 1.9 & 0.0 & 1.8 & 0.0 & 2.1 & 2.0 & 0.0 & 1.2 & 1.7 & 0.0 \\
\hline September & 1.9 & 0.0 & 2.0 & 0.0 & 1.9 & 0.0 & 1.9 & 0.0 & 2.0 & 2.0 & 0.0 & 1.2 & 1.7 & 0.0 \\
\hline October & 1.7 & 0.0 & 1.9 & 0.0 & 1.8 & 0.0 & 1.7 & 0.0 & 1.7 & 1.8 & 0.0 & 0.98 & 1.7 & 0.0 \\
\hline November & 1.7 & 0.02 & 1.9 & 0.0 & 1.9 & 0.0 & 1.7 & 0.02 & 1.5 & 1.8 & 0.03 & 0.9 & 1.7 & 0.01 \\
\hline December & 1.7 & $\underline{0.0}$ & 1.7 & $\underline{0.0}$ & 1.8 & $\underline{0.0}$ & 1.6 & $\underline{0.0}$ & $\underline{1.3}$ & 1.7 & $\underline{0.0}$ & $\underline{0.72}$ & 1.6 & $\underline{0.0}$ \\
\hline Average $\mathrm{mR} /$ week & 1.8 & 0.04 & 2.0 & 0.04 & 1.9 & 0.1 & 1.7 & 0.2 & 1.6 & 1.9 & 0.26 & 0.95 & 1.7 & 0.01 \\
\hline Total mR/year & 94 & 2.1 & 100 & 2.1 & 99 & 5.2 & 88 & 10.0 & 83 & 99 & 14 & 49 & 88 & 0.52 \\
\hline
\end{tabular}


Table B-2. 1968 Monthly Average Gross Beta Concentrations, Air Particulate Filters (pCi/m $\left.\mathrm{m}^{3}\right)$

\begin{tabular}{|c|c|c|c|c|c|c|c|c|c|}
\hline Month & $\begin{array}{c}\text { Average } \\
\text { Gross } \\
\text { Beta }\end{array}$ & ${ }^{7} \mathrm{Be}$ & ${ }^{65} \mathrm{Zn}$ & ${ }^{95} \mathrm{Zr}-\mathrm{Nb}$ & ${ }^{103} \mathrm{Ru}$ & ${ }^{131} \mathbf{I}$ & ${ }^{137} \mathrm{Cs}$ & ${ }^{140} \mathrm{Ba}-\mathrm{La}$ & ${ }^{144} \mathrm{Ce}$ \\
\hline January & 0.35 & 0.2 & $<0.001$ & 0.13 & 0.012 & 0.056 & $<0.005$ & 0.047 & 0.024 \\
\hline February & 0.31 & 0.29 & $<0.001$ & 0.08 & 0.012 & 0.004 & $<0.005$ & 0.015 & 0.02 \\
\hline March & 0.27 & 0.2 & $<0.001$ & 0.075 & 0.009 & $<0.001$ & $<0.005$ & 0.001 & 0.012 \\
\hline April & 0.36 & 0.25 & $<0.001$ & 0.12 & 0.015 & $<0.001$ & $<0.005$ & 0.001 & 0.016 \\
\hline May & 0.27 & 0.13 & $<0.001$ & 0.11 & 0.020 & $<0.001$ & 0.013 & $<0.001$ & 0.014 \\
\hline June & 0.24 & 0.15 & $<0.001$ & 0.044 & $<0.010$ & $<0.001$ & 0.009 & $<0.001$ & 0.05 \\
\hline July & 0.32 & 0.21 & $<0.001$ & 0.04 & $<0.010$ & $<0.001$ & 0.013 & $<0.001$ & 0.033 \\
\hline August & 0.20 & 0.15 & $<0.001$ & 0.024 & $<0.010$ & $<0.001$ & 0.008 & $<0.001$ & 0.048 \\
\hline September & 0.22 & 0.15 & 0.002 & 0.015 & $<0.010$ & 0.001 & 0.008 & $<0.001$ & 0.043 \\
\hline October & 0.20 & 0.13 & 0.002 & 0.01 & $<0.010$ & $<0.001$ & 0.005 & $<0.001$ & 0.023 \\
\hline November & 0.086 & 0.078 & 0.001 & 0.005 & $<0.010$ & $<0.001$ & 0.003 & $<0.001$ & 0.018 \\
\hline December & $\underline{0.089}$ & $\underline{0.089}$ & $\underline{0.001}$ & $\underline{0.004}$ & $\leq 0.010$ & $\leq 0.001$ & $\underline{0.003}$ & $<0.001$ & $\underline{0.017}$ \\
\hline Yearly Average & 0.24 & 0.17 & $<.0012$ & 0.055 & $<0.012$ & $<0.006$ & $<0.007$ & $<0.006$ & 0.027 \\
\hline
\end{tabular}


Table B-3. 1968 Monthly Average Gross Beta Concentrations and Total Gross Beta Activity in Precipitation

\begin{tabular}{|c|c|c|c|c|c|c|c|c|c|c|c|c|c|}
\hline \multirow[b]{2}{*}{ Month } & \multirow[b]{2}{*}{$\begin{array}{c}\text { Amount } \\
\text { Inches }\end{array}$} & \multirow{2}{*}{$\begin{array}{c}\text { Gross } \\
\text { Beta } \\
\text { Conc. } \\
\text { pCi/l } \\
\end{array}$} & \multirow{2}{*}{$\begin{array}{c}\text { Gross } \\
\text { Beta } \\
\text { Activity } \\
\text { nCi/m } \\
\end{array}$} & \multicolumn{10}{|c|}{ Nuclide Activity (nCi/m $\left.{ }^{2}\right)$} \\
\hline & & & & ${ }^{7} \mathbf{B e}$ & ${ }^{89} \mathrm{Sr}$ & ${ }^{90} \mathrm{Sr}$ & ${ }^{95} \mathrm{Zr}-\mathrm{Nb}$ & ${ }^{103} \mathbf{R u}$ & ${ }^{131} I$ & ${ }^{137} \mathrm{Cs}$ & ${ }^{140} \mathrm{Ba}-\mathrm{La}$ & ${ }^{141} \mathrm{Ce}$ & ${ }^{144} \mathrm{Ce}$ \\
\hline January & 2.4 & 480 & 29 & 5.2 & 0.51 & 0.09 & 2.1 & 0.81 & 1.90 & $<0.20$ & 3.50 & 1.9 & $<1.0$ \\
\hline February & 2.3 & 98 & 6 & 7.1 & 0.30 & 0.20 & 1.9 & 0.20 & 0.50 & $<0.20$ & 0.50 & 0.50 & $<1.0$ \\
\hline March & 7.2 & 61 & 11 & 9.9 & 0.30 & 0.30 & 3.3 & 0.30 & 0.40 & 0.30 & $<0.50$ & 0.40 & $<1.0$ \\
\hline April & 1.9 & 88 & 4.3 & 3.7 & 0.30 & 0.07 & 1.3 & 0.20 & $<0.10$ & 0.20 & $<0.50$ & 0.20 & $<1.0$ \\
\hline May & 4.1 & 100 & 11 & 1.8 & 0.14 & 0.24 & 2.1 & 0.30 & $<0.10$ & 0.20 & $<0.50$ & $<0.30$ & $<1.0$ \\
\hline June & 4.5 & 68 & 8.1 & 12 & 0.11 & 0.13 & 2.2 & $<0.10$ & $<0.10$ & 0.70 & $<0.50$ & $<0.30$ & 2.5 \\
\hline July & 0.42 & 98 & 1.2 & 1.5 & $<0.05$ & 0.043 & 1.4 & $<0.10$ & $<0.10$ & 0.10 & $<0.50$ & $<0.30$ & 0.3 \\
\hline August & 2.8 & 45 & 3.1 & 3.7 & $<0.05$ & 0.07 & 0.30 & $<0.10$ & $<0.10$ & 0.10 & $<0.50$ & $<0.30$ & 0.6 \\
\hline September & 1.6 & 32 & 1.8 & 2.4 & $<0.05$ & 0.08 & 0.20 & $<0.10$ & 0.10 & $<0.05$ & $<0.50$ & $<0.30$ & 1.2 \\
\hline October & 2.5 & 26 & 1.6 & 2.7 & $<0.05$ & 0.08 & 0.19 & $<0.10$ & 0.15 & 0.11 & $<0.50$ & $<0.30$ & $\cdot 1.1$ \\
\hline November & 6.9 & 19 & 3.3 & 5.8 & 0.02 & 0.16 & 0.30 & $<0.10$ & $<0.10$ & 0.10 & $<0.50$ & $<0.30$ & 1.3 \\
\hline December & $\underline{7.3}$ & $\underline{15}$ & $\underline{3.4}$ & $\underline{6.1}$ & $\underline{0.05}$ & $\underline{0.10}$ & $\underline{0.37}$ & $<0.10$ & $<0.10$ & $\underline{0.14}$ & $\leq 0.50$ & $\leq 0.30$ & - \\
\hline Total & 44 & & 84 & 62 & $<1.9$ & 1.6 & 16 & $<2.5$ & $<3.8$ & $<2.4$ & $<9.0$ & $<5.4$ & $<12$ \\
\hline Weighted Average ${ }^{a}$ & & 72 & & & & & & & & & & & \\
\hline
\end{tabular}

${ }^{a}$ Weighted by inches of rainfall.

$<$ means that the value is less than or equal to the detection limit or a summation or average value in which one of the components was a $<$ value. 
Table B-4. 1968 BGRR-HFBR Stack Emission

\begin{tabular}{|c|c|c|c|c|c|c|c|c|c|c|c|}
\hline \multirow[b]{2}{*}{ Month } & \multirow[b]{2}{*}{$\begin{array}{l}\text { BGRR } \\
\text { (MWd) } \\
\end{array}$} & \multirow[b]{2}{*}{$\begin{array}{l}\text { HFBR } \\
\text { (MWd) }\end{array}$} & \multirow[b]{2}{*}{$\begin{array}{c}\text { Air volume, } \\
\mathbf{m}^{3}\end{array}$} & \multicolumn{2}{|c|}{ Tritiated Water } & \multicolumn{2}{|c|}{${ }^{131} I$} & \multicolumn{2}{|c|}{${ }^{41} \mathrm{Ar}$} & \multicolumn{2}{|c|}{$\begin{array}{c}\text { Particulate } \\
\text { Gross Beta Activity }\end{array}$} \\
\hline & & & & $\begin{array}{c}\text { Amount } \\
\mathrm{Ci}\end{array}$ & $\begin{array}{c}\text { Conc. } \\
\mathrm{pCi} / \mathrm{m}^{3}\end{array}$ & $\mathbf{m C i}$ & $\mathbf{p C i} / \mathrm{m}^{3}$ & $\mathbf{C i}$ & $\mathrm{pCi} / \mathrm{m}^{3}$ & $\mathbf{C i}$ & $\mathbf{p C i} / \mathbf{m}^{3}$ \\
\hline January & 156 & 863 & $1.0 \mathrm{E}+08$ & 13 & $1.3 \mathrm{E}+05$ & 31 & $3.1 \mathrm{E}+02$ & $1.7 \mathrm{E}+05$ & $1.7 \mathrm{E}+09$ & 9.9 & $9.9 \mathrm{E}+04$ \\
\hline February & 139 & 1,052 & $8.5 \mathrm{E}+07$ & 13 & $1.5 \mathrm{E}+05$ & 22 & $2.6 \mathrm{E}+02$ & $1.3 \mathrm{E}+05$ & $1.5 \mathrm{E}+09$ & 7.8 & $9.2 \mathrm{E}+04$ \\
\hline March & 169 & 608 & $1.0 \mathrm{E}+08$ & 20 & $2.0 \mathrm{E}+05$ & 21 & $2.1 \mathrm{E}+02$ & $1.7 \mathrm{E}+05$ & $1.7 \mathrm{E}+09$ & 9.6 & $9.6 \mathrm{E}+04$ \\
\hline April & 127 & 956 & $8.5 E+07$ & 15 & $1.8 \mathrm{E}+05$ & 17 & $2.0 \mathrm{E}+02$ & $1.3 \mathrm{E}+05$ & $1.5 \mathrm{E}+09$ & 7.6 & $8.9 \mathrm{E}+04$ \\
\hline May & 157 & 868 & $1.3 \mathrm{E}+08$ & 19 & $1.5 \mathrm{E}+05$ & 16 & $1.2 \mathrm{E}+02$ & $1.5 \mathrm{E}+05$ & $1.2 \mathrm{E}+09$ & 9.2 & 7.1E+04 \\
\hline June & 103 & 948 & $7.6 \mathrm{E}+07$ & 24 & $3.2 E+05$ & 11 & $1.4 \mathrm{E}+02$ & $9.0 \mathrm{E}+04$ & $1.2 \mathrm{E}+09$ & 5.8 & $7.6 \mathrm{E}+04$ \\
\hline July & 0 & 765 & $1.9 \mathrm{E}+07$ & 38 & $2.0 \mathrm{E}+06$ & 0.069 & $3.7 \mathrm{E}+00$ & $0.0 \mathrm{E}+00$ & $0.0 \mathrm{E}+00$ & 0.1 & $5.3 \mathrm{E}+03$ \\
\hline August & 0 & 1,048 & $1.9 E_{1} 07$ & 47 & $2.5 \mathrm{E}+06$ & $<0.01$ & 5.3E-01 & $0.0 \mathrm{E}+00$ & $\hat{\mathrm{u}} . \hat{\mathrm{U}} \mathrm{E}+\hat{\mathrm{O}} \hat{0}$ & $\hat{0.1}$ & $5.3 \mathrm{E}+03$ \\
\hline September & 0 & 802 & $1.8 \mathrm{E}+07$ & 44 & $2.4 \mathrm{E}+06$ & $<0.01$ & $5.6 \mathrm{E}-01$ & $0.0 \mathrm{E}+00$ & $0.0 \mathrm{E}+00$ & 0.1 & $5.6 \mathrm{E}+03$ \\
\hline October & 0 & 678 & $1.9 \mathrm{E}+07$ & 62 & $3.3 E+06$ & $<0.01$ & $5.3 \mathrm{E}-01$ & $0.0 \mathrm{E}+00$ & $0.0 \mathrm{E}+00$ & 0.1 & $5.3 \mathrm{E}+03$ \\
\hline November & 8 & 951 & $1.9 \mathrm{E}+07$ & 52 & $2.7 \mathrm{E}+06$ & 0.17 & $8.9 E+00$ & $5.5 \mathrm{E}+03$ & $2.9 E+08$ & 0.5 & $2.6 \mathrm{E}+04$ \\
\hline December & $\underline{0}$ & $\underline{794}$ & $1.9 \mathrm{E}+07$ & $\underline{37}$ & $\underline{1.9 \mathrm{E}+06}$ & $\leq 0.01$ & $\underline{5.3 \mathrm{E}-01}$ & $\underline{0.0 \mathrm{E}+00}$ & $\underline{0.0 \mathrm{E}+00}$ & $\underline{0.1}$ & $\underline{5.3 \mathrm{E}+03}$ \\
\hline Annual total & 859 & 10,333 & $6.9 \mathrm{E}+08$ & 380 & & $<120$ & & $8.5 \mathrm{E}+05$ & & 51 & \\
\hline Average & & & & & $1.3 E+06$ & & $8.5 E+05$ & & $7.6 \mathrm{E}+08$ & & $4.8 \mathrm{E}+04$ \\
\hline
\end{tabular}


Table B-5. 1968 Clarifier. Flow, Gross Beta, Tritiated Water, ${ }^{90} \mathrm{Sr}$, and ${ }^{137} \mathrm{Cs}$ Amounts and Concentrations

\begin{tabular}{|c|c|c|c|c|c|c|c|c|c|}
\hline \multirow[b]{2}{*}{ Month } & \multirow[b]{2}{*}{$\begin{array}{l}\text { Flow } \\
10^{9} 1\end{array}$} & \multicolumn{2}{|c|}{ Gross Beta $^{a}$} & \multicolumn{2}{|c|}{ Tritiated Water } & \multicolumn{2}{|c|}{${ }^{90} \mathrm{Sr}$} & \multicolumn{2}{|c|}{${ }^{137} \mathrm{Cs}$} \\
\hline & & $\begin{array}{l}\text { Conc. } \\
\text { pCi/l }\end{array}$ & $\begin{array}{c}\text { Amount } \\
\text { mCi }\end{array}$ & $\begin{array}{l}\text { Conc. } \\
\text { pCi// }\end{array}$ & $\begin{array}{c}\text { Amount } \\
\text { mCi }\end{array}$ & $\begin{array}{l}\text { Conc. } \\
\text { pCi// }\end{array}$ & $\begin{array}{c}\text { Amount } \\
\text { mCi }\end{array}$ & $\begin{array}{l}\text { Conc. } \\
\text { pCi// }\end{array}$ & $\begin{array}{c}\text { Amount } \\
\text { mCi }\end{array}$ \\
\hline January & 0.087 & 27 & 2.3 & 14,000 & 1,200 & 7.0 & 0.61 & 6.0 & 0.52 \\
\hline February & 0.097 & 17 & 1.7 & 7,500 & 730 & 4.0 & 0.39 & 1.0 & 0.10 \\
\hline March & 0.12 & 24 & 2.9 & 2,300 & 280 & 2.0 & 0.24 & $<1.0$ & 0.12 \\
\hline April & 0.12 & 14 & 1.7 & 22,000 & 2,700 & 1.0 & 0.12 & $<1.0$ & 0.12 \\
\hline May & 0.13 & 19 & 2.5 & 23,000 & 3,000 & 1.3 & 0.17 & 1.0 & 0.13 \\
\hline June & 0.18 & 11 & 2.0 & 2,700 & 490 & 0.5 & 0.10 & 1.0 & 0.18 \\
\hline July & 0.15 & 15 & 2.3 & 3,200 & 480 & 0.5 & 0.07 & 3.0 & 0.45 \\
\hline August & 0.15 & 12 & 1.8 & 6,700 & 1,000 & 0.5 & 0.08 & 1.0 & 0.15 \\
\hline September & 0.15 & 11 & 1.6 & 3,200 & 470 & 0.6 & 0.09 & 1.0 & 0.15 \\
\hline October & 0.12 & 9.0 & 1.1 & 57,000 & 6,700 & 0.45 & 0.05 & 1.0 & 0.12 \\
\hline November & 0.10 & 15 & 1.5 & 48,000 & 4,900 & 2.3 & 0.23 & 1.0 & 0.10 \\
\hline December & $\underline{0.095}$ & $\underline{8.0}$ & $\underline{0.8}$ & $\underline{8,600}$ & $\underline{820}$ & $\underline{0.2}$ & $\underline{0.02}$ & $\underline{0.6}$ & $\underline{0.06}$ \\
\hline Total & 1.5 & & 22 & & 23,000 & & 2.2 & & 2.2 \\
\hline Weighted Average $^{\mathrm{b}}$ & & 15 & & 15,000 & & 1.5 & & $<1.5$ & \\
\hline
\end{tabular}

${ }^{a}$ Includes gamma-only emitters; does not include tritiated water.

${ }^{\mathrm{b}}$ Weighted average concentration $=$ total amount $(\mathrm{mCi}) /$ total flow $\left(10^{9} \mathrm{l}\right)$. 
Table B-6. 1968 Chlorinating Plant. Flow, Gross Beta, Tritiated Water, ${ }^{90} \mathrm{Sr}$, and ${ }^{137} \mathrm{Cs}$ Amounts and Concentrations

\begin{tabular}{|c|c|c|c|c|c|c|c|c|c|}
\hline \multirow[b]{2}{*}{ Month } & \multirow[b]{2}{*}{$\begin{array}{c}\text { Flow } \\
10^{9} 1\end{array}$} & \multicolumn{2}{|c|}{ Gross Beta $^{a}$} & \multicolumn{2}{|c|}{ Tritiated Water } & \multicolumn{2}{|c|}{${ }^{90} \mathrm{Sr}$} & \multicolumn{2}{|c|}{${ }^{137} \mathrm{Cs}$} \\
\hline & & $\begin{array}{l}\text { Conc. } \\
\mathrm{pCi} / \mathrm{l}\end{array}$ & $\begin{array}{c}\text { Amount } \\
\text { mCi }\end{array}$ & $\begin{array}{l}\text { Conc. } \\
\mathrm{pCi} / \mathbf{l}\end{array}$ & $\begin{array}{c}\text { Amount } \\
\text { mCi }\end{array}$ & $\begin{array}{l}\text { Conc. } \\
\mathrm{pCi} / \mathrm{l} \\
\end{array}$ & $\begin{array}{c}\text { Amount } \\
\mathrm{mCi}\end{array}$ & $\begin{array}{l}\text { Conc. } \\
\mathrm{pCi} / \mathrm{l}\end{array}$ & $\begin{array}{c}\text { Amount } \\
\text { mCi }\end{array}$ \\
\hline$\overline{\text { January }}$ & 0.067 & 21 & 1.4 & 16,000 & 1,100 & 2.0 & 0.13 & 9.0 & 0.6 \\
\hline February & 0.057 & 17 & 0.97 & 8,200 & 470 & 3.0 & 0.17 & 9.0 & 0.51 \\
\hline March & 0.07 & 29 & 2.0 & 2,800 & 200 & 4.0 & 0.28 & 7.0 & 0.49 \\
\hline April & 0.1 & 17 & 1.7 & 19,000 & 1,900 & 2.0 & 0.20 & 5.0 & 0.50 \\
\hline May & 0.11 & 19 & 2.1 & 15,000 & 1,700 & 1.8 & 0.20 & 8.0 & 0.88 \\
\hline June & 0.15 & 14 & 2.1 & 2,500 & 380 & 0.95 & 0.14 & 9.0 & 1.4 \\
\hline July & 0.079 & 17 & 1.3 & 2,000 & 160 & 0.8 & 0.06 & 6.0 & 0.47 \\
\hline August & 0.13 & 15 & 2.0 & 6,700 & 870 & 0.6 & 0.08 & 8.0 & 1.0 \\
\hline September & 0.13 & 15 & 2.0 & 3,800 & 490 & 1.3 & 0.17 & 8.0 & 1.0 \\
\hline October & 0.11 & 10 & 1.1 & 32,000 & 3,500 & 0.86 & 0.95 & 5.0 & 0.55 \\
\hline November & 0.087 & 11 & 0.96 & 35,000 & 3,000 & 4.6 & 0.40 & 5.0 & 0.44 \\
\hline December & $\underline{0.051}$ & $\underline{8}$ & 0.41 & $\underline{14,000}$ & $\underline{710}$ & $\underline{0.3}$ & 0.02 & $\underline{5.0}$ & $\underline{0.26}$ \\
\hline Total & 1.1 & & 18 & & 14,000 & & 2.0 & & 8.1 \\
\hline Weighted Average $^{b}$ & & 16 & & 13,000 & & 1.8 & & 7.4 & \\
\hline
\end{tabular}

${ }^{a}$ Includes gamma-only emitters; does not include tritiated water.

${ }^{b}$ Weighted average concentration $=$ total amount $(\mathrm{mCi}) /$ total flow $\left(10^{9} 1\right)$. 
Table B-7. 1968 "M" (Former Perimeter). Flow, Gross Beta, Tritiated Water, ${ }^{90} \mathrm{Sr}$, and ${ }^{137}$ Cs Amounts and Concentrations

\begin{tabular}{|c|c|c|c|c|c|c|c|c|c|}
\hline \multirow[b]{2}{*}{ Month } & \multirow[b]{2}{*}{$\begin{array}{l}\text { Flow } \\
10^{9} !\end{array}$} & \multicolumn{2}{|c|}{ Gross Beta $^{\mathrm{a}}$} & \multicolumn{2}{|c|}{ Tritiated Water } & \multicolumn{2}{|c|}{${ }^{90} \mathrm{Sr}$} & \multicolumn{2}{|c|}{${ }^{137} \mathrm{Cs}$} \\
\hline & & $\begin{array}{l}\text { Conc. } \\
\text { pCi/l }\end{array}$ & $\begin{array}{c}\text { Amount } \\
\text { mCi }\end{array}$ & $\begin{array}{l}\text { Conc. } \\
\text { pCi// }\end{array}$ & $\begin{array}{c}\text { Amount } \\
\mathbf{m C i}\end{array}$ & $\begin{array}{l}\text { Conc. } \\
\text { pCi// }\end{array}$ & $\begin{array}{c}\text { Amount } \\
\mathbf{m C i}\end{array}$ & $\begin{array}{l}\text { Conc. } \\
\text { pCi/l }\end{array}$ & $\underset{\mathrm{mCi}}{\text { Amount }}$ \\
\hline $\begin{array}{l}\text { January } \\
\end{array}$ & 0.083 & 21 & 1.7 & 14,000 & 1,200 & 2.0 & 0.16 & 8.0 & 0.64 \\
\hline February & 0.074 & 17 & 1.2 & 8,000 & 590 & 3.0 & 0.21 & 7.0 & 0.49 \\
\hline March & 0.11 & 20 & 2.2 & 2,500 & 280 & 2.0 & 0.22 & 4.0 & 0.44 \\
\hline April & 0.12 & 15 & 1.8 & 19,000 & 2,200 & 2.0 & 0.24 & 4.0 & 0.48 \\
\hline May & 0.12 & 17 & 2.0 & 15,000 & 1,800 & 1.8 & 0.22 & 7.0 & 0.84 \\
\hline June & 0.15 & 16 & 2.4 & 2,500 & 380 & 1.2 & 0.18 & 9.0 & 1.4 \\
\hline July & 0.10 & 15 & 1.5 & 2,200 & 220 & 1.2 & 0.12 & 6.0 & 0.60 \\
\hline August & 0.12 & 15 & 1.8 & 7,600 & 910 & 0.89 & 0.11 & 8.0 & 0.96 \\
\hline September & 0.082 & 12 & 0.96 & 4,000 & 320 & 1.0 & 0.08 & 7.0 & 0.56 \\
\hline October & 0.10 & 10 & 1.0 & 37,000 & 3,700 & 1.0 & 0.10 & 5.0 & 0.50 \\
\hline November & 0.10 & 15 & 1.5 & 35,000 & 3,500 & 4.1 & 0.41 & 5.2 & 0.52 \\
\hline December & $\underline{0.10}$ & $\underline{9}$ & $\underline{0.90}$ & $\underline{12,000}$ & $\underline{1,200}$ & $\underline{0.8}$ & $\underline{0.08}$ & 4.0 & $\underline{0.40}$ \\
\hline Total & 1.3 & & 19 & & 16,000 & & 2.1 & & 7.8 \\
\hline Weighted Average & & 15 & & 12,000 & & 1.6 & & 6.0 & \\
\hline
\end{tabular}

${ }^{a}$ Includes gamma-only emitters; does not include tritiated water.

${ }^{\mathrm{b}}$ Weighted average concentration $=$ total amount $(\mathrm{mCi}) /$ total flow $\left(10^{9} 1\right)$. 
Table B-8. 1968 "Q" (Current Perimeter). Flow, Gross Beta, Tritiated Water, ${ }^{90} \mathrm{Sr}$, and ${ }^{137} \mathrm{Cs}$ Amounts and Concentrations ${ }^{\mathrm{a}}$

\begin{tabular}{|c|c|c|c|c|c|c|c|c|c|}
\hline \multirow[b]{2}{*}{ Month } & \multirow[b]{2}{*}{$\begin{array}{c}\text { Flow } \\
10^{9} 1\end{array}$} & \multicolumn{2}{|c|}{ Gross Beta $^{b}$} & \multicolumn{2}{|c|}{ Tritiated Water } & \multicolumn{2}{|c|}{${ }^{90} \mathrm{Sr}$} & \multicolumn{2}{|c|}{${ }^{137} \mathrm{Cs}$} \\
\hline & & $\begin{array}{l}\text { Conc. } \\
\text { pCi/l }\end{array}$ & $\underset{\mathbf{m C i}}{\text { Amount }}$ & $\begin{array}{l}\text { Conc. } \\
\text { pCi/l }\end{array}$ & $\begin{array}{c}\text { Amount } \\
\mathbf{m C i}\end{array}$ & $\begin{array}{l}\text { Conc. } \\
\text { pCi/l }\end{array}$ & $\underset{\mathbf{m C i}}{\text { Amount }}$ & $\begin{array}{l}\text { Conc. } \\
\mathrm{pCi} / 1\end{array}$ & $\begin{array}{c}\text { Amount } \\
\mathbf{m C i}\end{array}$ \\
\hline January & 0.083 & 21 & 1.7 & 14,000 & 1,200 & 2.0 & 0.17 & 8.0 & 0.66 \\
\hline February & 0.074 & 17 & 1.3 & 8,000 & 590 & 3.0 & 0.22 & 7.0 & 0.52 \\
\hline March & 0.11 & 20 & 2.2 & 2,500 & 280 & 2.0 & 0.22 & 4.0 & 0.44 \\
\hline April & 0.12 & 15 & 1.8 & 19,000 & 2,300 & 2.0 & 0.24 & 4.0 & 0.48 \\
\hline May & 0.12 & 17 & 2.0 & 15,000 & 1,800 & 1.8 & 0.22 & 7.0 & 0.84 \\
\hline June & 0.15 & 16 & 2.4 & 2,500 & 380 & 1.2 & 0.18 & 9.0 & 1.40 \\
\hline July & 0.049 & 15 & 0.7 & 2,200 & î̀o & 1.2 & 0.06 & 6.0 & 0.29 \\
\hline August & 0.12 & 15 & 1.8 & 7,600 & 910 & 0.89 & 0.11 & 8.0 & 0.96 \\
\hline September & 0.082 & 12 & 1.0 & 4,000 & 330 & 1.0 & 0.08 & 7.0 & 0.57 \\
\hline October & 0.10 & 10 & 1.0 & 37,000 & 3,700 & 1.0 & 0.10 & 5.0 & 0.50 \\
\hline November & 0.0001 & $11^{\mathrm{c}}$ & 0.0011 & $47,000^{\mathrm{c}}$ & 4.7 & - & - & - & - \\
\hline December & $\underline{0.029}$ & $\underline{8}^{c}$ & $\underline{0.2}$ & $\underline{13,000^{\mathrm{c}}}$ & $\underline{380}$ & $1.0^{\mathrm{c}}$ & $\underline{0.03}$ & $\underline{5.0^{c}}$ & $\underline{0.15}$ \\
\hline Total & 1.0 & & 16.0 & & 12,000 & & 1.6 & & 6.8 \\
\hline Weighted Aver & & 16 & & 12,000 & & 1.6 & & 6.8 & \\
\hline
\end{tabular}

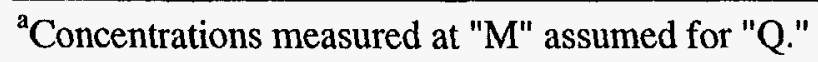

${ }^{a}$ Includes gamma-only emitters; does not include tritiated water.

cActual measurements at new weir used at "Q" for November and December.

${ }^{\mathrm{d}}$ Weighted average concentration $=$ total amount $(\mathrm{mCi}) /$ total flow $\left(10^{9} \mathrm{l}\right)$. 
Table B-9. 1968 Monthly Downstream and Control Location Water Grab Samples. Gross Beta and Tritiated Water Concentrations

\begin{tabular}{|c|c|c|c|c|c|c|c|c|c|c|c|c|c|}
\hline \multirow[b]{2}{*}{ Month } & \multicolumn{8}{|c|}{ Downstream Locations } & \multicolumn{5}{|c|}{ Control Locations } \\
\hline & $\mathbf{A}$ & $\mathbf{B}$ & $\mathrm{C}$ & D & $\mathbf{K}$ & $\mathbf{L}$ & $\mathbf{M}^{\mathrm{a}}$ & $\mathbf{Q}$ & $\mathbf{E}$ & $\mathbf{F}$ & $\mathbf{H}$ & I & $\mathbf{J}$ \\
\hline \multicolumn{14}{|c|}{ Gross Beta (pCi/l) } \\
\hline January & 11 & 12 & 21 & 14 & 19 & 13 & 23 & 52 & - & 26 & 12 & 46 & 20 \\
\hline February & 9.0 & 8.0 & 6.0 & 6.0 & 43 & 23 & 16 & 18 & 5.0 & 9.0 & 3.0 & 26 & 17 \\
\hline March & 15 & 9.0 & 6.0 & 42 & 11 & 10 & 14 & 9.0 & - & 11 & 3.0 & 2.0 & 9.0 \\
\hline April & 8.0 & 7.0 & 4.0 & 5.0 & 14 & 14 & 14 & 22 & 4.0 & 7.0 & 2.0 & 12 & 7.0 \\
\hline May & 9 & 6.0 & 7.0 & 8.0 & 12 & 11 & 17 & 12 & 6.0 & 4.0 & 4.0 & 8.0 & 6.0 \\
\hline June & 10 & 9.0 & 13 & 5.0 & 14 & 12 & 20 & 17 & - & 10 & 3.0 & 40 & 7.0 \\
\hline July & - & - & - & - & - & - & - & - & - & - & - & - & - \\
\hline August & 6.0 & 3.0 & 4.0 & 39 & 16 & 11 & 10 & 20 & - & 9.0 & 2.0 & 9.0 & 16 \\
\hline September & 7.0 & 7.0 & 4.0 & 11 & 10 & 14 & 12 & 21 & - & 150 & 5.0 & 7.0 & 7.0 \\
\hline October & 6.0 & 2.0 & 4.0 & 4.0 & 4.0 & 12 & 9 & 10 & - & 5.0 & 1.0 & 15 & 18 \\
\hline November & 8.0 & 8.0 & 5.0 & 4.0 & 13 & 15 & 10 & $11^{a}$ & 7.0 & 10 & 3.0 & $<1.0$ & 6.0 \\
\hline December & $\underline{5.0}$ & $\underline{4.0}$ & $\underline{6.0}$ & $\underline{3.0}$ & $\underline{11}$ & $\underline{15}$ & $\underline{9}$ & $\underline{9^{a}}$ & 5.0 & 9.0 & 2.0 & $\underline{7.0}$ & $\underline{5.0}$ \\
\hline Yearly Average & 8.5 & 7.0 & 7.0 & 13 & 15 & 14 & 14 & 18 & 5.4 & 23 & 4.0 & $<16$ & 11 \\
\hline \multicolumn{14}{|c|}{ Tritiated Water (pCi/l) } \\
\hline January & $b$ & b & b & $b$ & b & $b$ & b & $\mathrm{b}$ & b & $\mathbf{b}$ & $\mathrm{b}$ & b & b \\
\hline February & $<1,000$ & 1,000 & $<1,000$ & $<1,000$ & 8,000 & 6,000 & 7,000 & 6,000 & 1,000 & $<1,000$ & $<1,000$ & $<1,000$ & 1,000 \\
\hline March & $<1,000$ & 1,400 & $<1,000$ & $<1,000$ & $<1,000$ & 1,600 & 3,000 & $<1,000$ & - & $<1,000$ & $<1,000$ & $<1,000$ & $<1,000$ \\
\hline April & 3,800 & 1,800 & 1,600 & $<1,000$ & 17,000 & 22,200 & 26,000 & 8,500 & $<1,000$ & 1,400 & $<1,000$ & $<1,000$ & $<1,000$ \\
\hline May & $<1,000$ & $<1,000$ & 1,300 & $<1,000$ & 13,000 & 13,000 & 37,000 & 2,000 & - & $<1,000$ & $<1,000$ & $<1,000$ & $<1,000$ \\
\hline June & $<1,000$ & $<1,000$ & $<1,000$ & 1,200 & 3,800 & 2,000 & 2,000 & 2,200 & $<1,000$ & $<1,000$ & 1,800 & $<1,000$ & 1,400 \\
\hline July & - & - & - & - & - & - & - & - & - & - & - & - & - \\
\hline August & $<1,000$ & $<1,000$ & $<1,000$ & $<1,000$ & 7,200 & 7,900 & 20,000 & 15,000 & - & 1,000 & $<1,000$ & $<1,000$ & $<1,000$ \\
\hline September & $<1,000$ & $<1,000$ & $<1,000$ & $<1,000$ & $<1,000$ & $<1,000$ & 1,000 & $<1,000$ & - & $<1,000$ & $<1,000$ & 1,000 & $<1,000$ \\
\hline October & $<1,000$ & $<1,000$ & $<1,000$ & $<1,000$ & 4,000 & 5,000 & 4,000 & 5,700 & - & $<1,000$ & 1,100 & $<1,000$ & $<1,000$ \\
\hline November & $<1,000$ & $<1,000$ & $<1,000$ & $<1,000$ & 8,000 & $<1,000$ & 12,000 & $14,000^{a}$ & $<1,000$ & $<1,000$ & $<1,000$ & $<1,000$ & $<1,000$ \\
\hline December & 2,000 & 1,000 & $\leq 1,000$ & $\leq 1,000$ & 4,000 & $\underline{4,000}$ & $\underline{7,000}$ & $\underline{20,000^{\mathrm{a}}}$ & $\leq 1,000$ & $\leq 1,000$ & $\leq 1,000$ & $\leq 1,000$ & $\leq 1,000$ \\
\hline Yearly Average & $<1,400$ & $<1,100$ & $<1,100$ & $<1,000$ & $<6,700$ & $<6,400$ & 12,000 & $<7,600$ & $<1,000$ & $<1,100$ & $<1,100$ & $<1,000$ & $<1,000$ \\
\hline
\end{tabular}

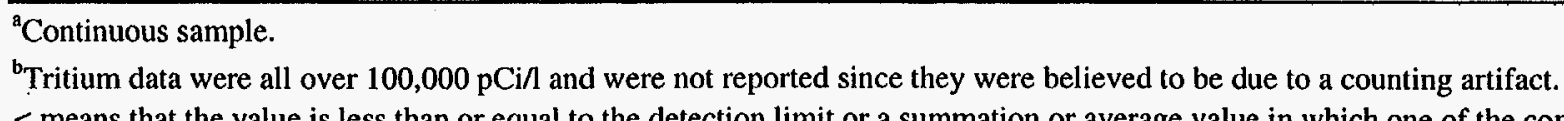

$<$ means that the value is less than or equal to the detection limit or a summation or average value in which one of the components was a $<$ value. 
Table B-10. 1968 Bottom Sediment Sample Concentrations

\begin{tabular}{|c|c|c|c|c|c|c|}
\hline Month & $\begin{array}{c}\text { Peconic } \\
\text { Location } \\
\end{array}$ & $\begin{array}{l}{ }^{60} \mathrm{Co} \\
\mathrm{pCi} / \mathrm{g} \\
(\mathrm{dry}) \\
\end{array}$ & $\begin{array}{c}{ }^{65} \mathrm{Zn} \\
\mathrm{pCi} / \mathrm{g}(\mathrm{dry}) \\
\end{array}$ & $\begin{array}{c}{ }^{95} \mathrm{Zr}-\mathrm{Nb} \\
\mathrm{pCi} / \mathrm{g} \\
\text { (dry) }\end{array}$ & $\begin{array}{l}{ }^{137} \mathrm{Cs} \\
\mathrm{pCi} / \mathrm{g} \\
\text { (dry) }\end{array}$ & $\begin{array}{l}{ }^{144} \mathrm{Ce} \\
\mathrm{pCi} / \mathrm{g} \\
\text { (dry) }\end{array}$ \\
\hline \multirow[t]{8}{*}{ March } & $\mathrm{K}$ & 0.3 & 0.1 & $<0.1$ & 1.5 & 1.0 \\
\hline & $\mathrm{L}$ & 2.3 & 0.7 & $<0.1$ & 5.8 & 0.2 \\
\hline & M & 24 & 1.5 & $<0.1$ & 13 & 11 \\
\hline & $Q$ & 3.7 & 0.4 & 0.9 & 3.3 & 2.2 \\
\hline & A & $<0.1$ & $<0.1$ & 0.2 & 0.7 & 0.6 \\
\hline & B & $<0.1$ & $<0.1$ & 0.1 & 0.5 & 0.2 \\
\hline & $\mathrm{C}$ & 0.2 & 0.1 & 0.1 & 0.9 & 1.0 \\
\hline & D & $<0.1$ & $<0.1$ & $<0.1$ & 0.3 & 0.3 \\
\hline \multirow[t]{4}{*}{ Controls } & $\mathrm{F}$ & $<0.1$ & $<0.1$ & $<0.1$ & 0.9 & $<0.1$ \\
\hline & $\mathrm{H}$ & $<0.1$ & $<0.1$ & 1.4 & $<0.1$ & 0.5 \\
\hline & I & $<0.1$ & $<0.1$ & 0.9 & 0.5 & 0.4 \\
\hline & $\mathbf{J}$ & $<0.1$ & $<0.1$ & 0.4 & $<0.1$ & 0.1 \\
\hline \multirow[t]{2}{*}{ Sumps } & $\mathrm{N}$ & $<0.1$ & $<0.1$ & 1.6 & 2.1 & 0.5 \\
\hline & $\mathrm{O}$ & 0.2 & $<0.1$ & 0.3 & 0.3 & $<0.1$ \\
\hline July & $\mathrm{M}$ & 11 & - & - & 8.3 & - \\
\hline
\end{tabular}

the detection limit or a summation or average value in which one of the components was a $<$ value. 


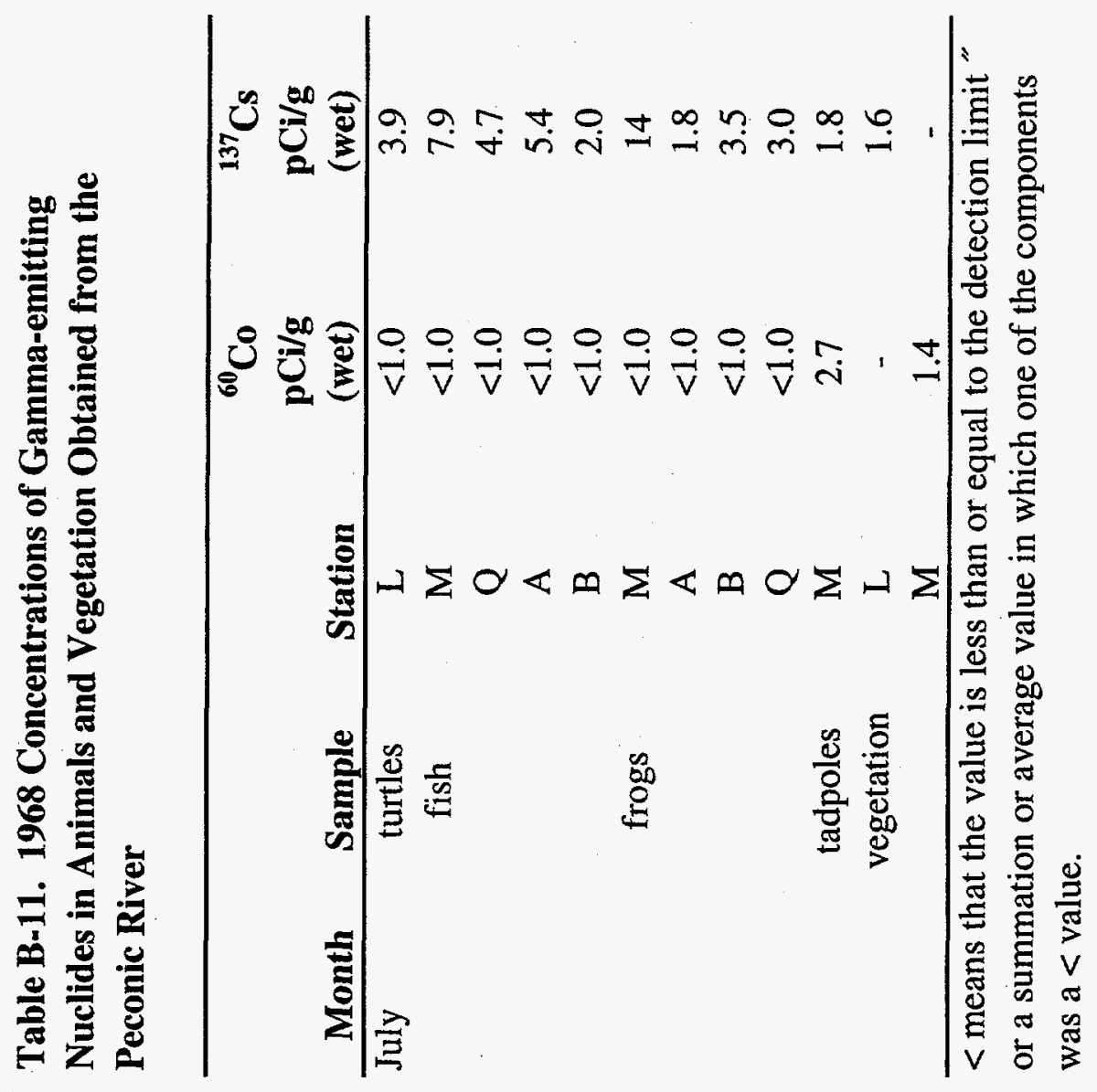

B-11 
Table B-12. 1968 Gross Beta and Tritiated Water Concentrations in Potable and Cooling Water Supply Wells

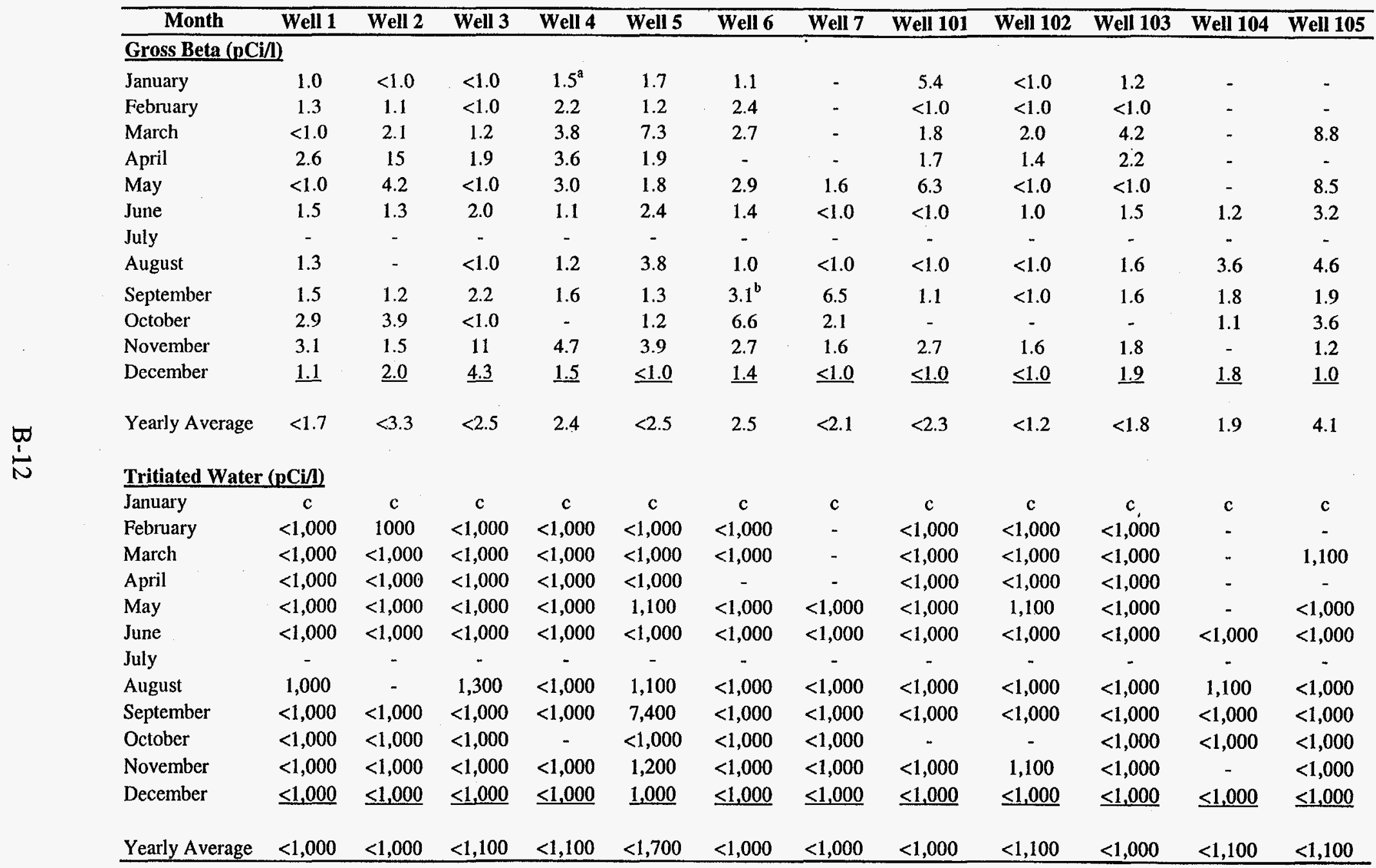

${ }^{\mathrm{a}}$ Resampled; original value was $26 \mathrm{pCi} / 1$.

${ }^{\mathrm{b}}$ Resampled; orginal value was $220 \mathrm{pCi} / \mathrm{l}$.

${ }^{c}$ Tritium data were all over $100,000 \mathrm{pCi} / \mathrm{l}$ and were not reported since they were believed to be due to a counting artifact.

$<$ means that the value is less than or equal to the detection limit or a summation or average value in which one of the components was a $<$ value. 


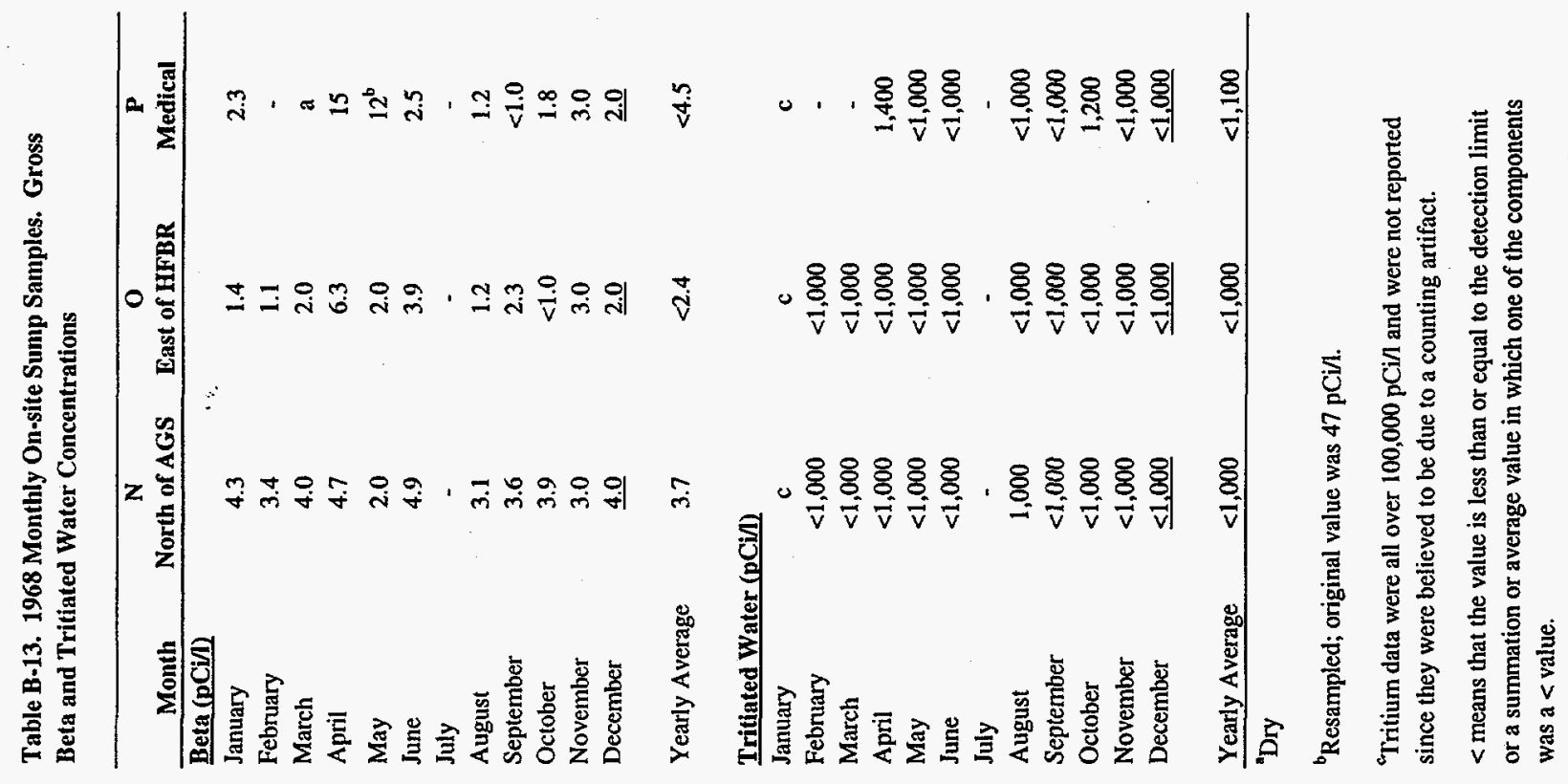


Table B-14. Concentrations in 1968 Milk Samples from Off-site Dairies

\begin{tabular}{|c|c|c|c|c|c|c|c|c|c|}
\hline \multirow[b]{2}{*}{ Month } & \multicolumn{3}{|c|}{ Farm B' $(8 \mathrm{~km} \mathrm{SW})$} & \multicolumn{3}{|c|}{ Farm C (10 km SE) } & \multicolumn{3}{|c|}{ Farm D $(15 \mathrm{~km} \mathrm{NW})$} \\
\hline & $\begin{array}{l}{ }^{65} \mathrm{Zn} \\
\mathrm{pCi} / 1\end{array}$ & $\begin{array}{c}{ }^{131} \mathrm{I} \\
\mathrm{pCi} / 1\end{array}$ & $\begin{array}{l}{ }^{137} \mathrm{Cs} \\
\mathrm{pCi} / 1\end{array}$ & $\begin{array}{l}{ }^{65} \mathrm{Zn} \\
\mathrm{pCi} / 1\end{array}$ & $\begin{array}{l}{ }^{131} \mathrm{I} \\
\mathrm{pCi} / /\end{array}$ & $\begin{array}{l}{ }^{137} \mathrm{Cs} \\
\mathrm{pCi} /\end{array}$ & $\begin{array}{l}{ }^{65} \mathrm{Zn} \\
\text { pCi// }\end{array}$ & $\begin{array}{c}131 \mathrm{I} \\
\mathrm{pCi} / \mathrm{I}\end{array}$ & $\begin{array}{l}{ }^{137} \mathrm{Cs} \\
\mathrm{pCi} /\end{array}$ \\
\hline January & $<10$ & 4.0 & 8.0 & $<10$ & 3.0 & 8.0 & $<10$ & 5.0 & 14 \\
\hline February & $<10$ & $<1.0$ & 8.0 & $<10$ & $<1.0$ & $<5.0$ & $<10$ & 3.0 & 11 \\
\hline March & $<10$ & 2.0 & 12 & $<10$ & 2.0 & 19 & $<10$ & 2.0 & 8.0 \\
\hline April & $<10$ & 1.0 & 7.0 & $<10$ & 1.0 & 13 & $<10$ & 3.0 & 8.0 \\
\hline May & $<10$ & 1.0 & 9.0 & $<10$ & 1.0 & 9.0 & $<10$ & 1.0 & 5.0 \\
\hline June & $<10$ & 1.0 & 9.0 & $<10$ & 1.0 & 18 & $<10$ & 1.0 & 15 \\
\hline Juiy & $<10$ & 1.0 & 15 & $<10$ & 2.0 & 4.0 & $<10$ & 2.0 & 9.0 \\
\hline August & $29^{\mathrm{a}}$ & 1.0 & 11 & $23^{a}$ & 3.0 & 20 & $<10$ & 2.0 & 14 \\
\hline September & $<10$ & 1.0 & 15 & $<10$ & 1.0 & 9.0 & $<10$ & 2.0 & 13 \\
\hline October & $33^{\mathrm{a}}$ & 2.0 & 17 & $35^{\mathrm{a}}$ & 2.0 & 11 & $42^{\mathrm{a}}$ & 2.0 & 17 \\
\hline November $^{b}$ & - & - & - & - & - & - & - & - & - \\
\hline December $^{b}$ & - & - & - & - & - & - & - & - & - \\
\hline Yearly Average & $<14$ & $<4.5$ & 11 & $<14$ & $<1.7$ & $<12$ & $<13$ & 2.3 & 11 \\
\hline
\end{tabular}

${ }^{\mathrm{a}}$ See section 5.2.

${ }^{\mathrm{b}}$ Next quarterly sampling in January 1969.

$<$ means that the value is less than or equal to the detection limit or a summation or average value in which one of the components was a $<$ value. 
Table B-15. Concentrations in 1968 Vegetation Sampled from Off-site Farms

\begin{tabular}{|c|c|c|c|c|c|}
\hline & & ${ }^{7} \mathbf{B e}$ & ${ }^{95} \mathrm{Zr}-\mathrm{Nb}$ & ${ }^{137} \mathrm{Cs}$ & ${ }^{144} \mathrm{Ce}$ \\
\hline Location & Month & \multicolumn{4}{|c|}{ pCi/kg (wet) } \\
\hline \multirow[t]{2}{*}{ Farm A (3 km NW) } & July & 500 & $<200$ & 100 & 600 \\
\hline & October & 1,900 & 400 & 1,300 & 800 \\
\hline \multirow[t]{2}{*}{ Farm B' $(8 \mathrm{~km} \mathrm{SW})$} & July & 1,200 & 300 & 100 & 1,100 \\
\hline & October & 1,000 & 100 & 100 & 100 \\
\hline \multirow[t]{2}{*}{ Farm C (10 km SE) } & July & 2,300 & 500 & 300 & 1,000 \\
\hline & October & 1,000 & 200 & 200 & $<100$ \\
\hline \multirow[t]{2}{*}{ Farm D $(15 \mathrm{~km} \mathrm{NW})$} & July & 800 & 200 & $<100$ & 2,100 \\
\hline & October & 900 & 100 & $<100$ & 300 \\
\hline \multirow[t]{2}{*}{ Farm H (6 km NE) } & July & $<500$ & 400 & 100 & 3,100 \\
\hline & October & 1,700 & 100 & 100 & 100 \\
\hline
\end{tabular}

$<$ means that the value is less than or equal to the detection limit or a summation or average value in which one of the components was a $<$ value. 
Table B-16. Concentrations in 1968 Soil Sampled from Off-site Farms

\begin{tabular}{|c|c|c|c|c|c|c|c|}
\hline & & ${ }^{7} \mathbf{B e}$ & ${ }^{95} \mathrm{Zr}-\mathrm{Nb}$ & ${ }^{137} \mathrm{Cs}$ & ${ }^{144} \mathrm{Ce}$ & ${ }^{238} \mathrm{U}$ & ${ }^{232} \mathrm{Th}$ \\
\hline Location & Month & \multicolumn{6}{|c|}{$\mathrm{pCi} / \mathrm{kg}$ (dry) } \\
\hline \multirow[t]{2}{*}{ Farm A $(3 \mathrm{~km} \mathrm{NW})$} & July & $<500$ & 300 & 600 & $<100$ & 900 & 700 \\
\hline & October & $<500$ & 300 & 2,000 & 200 & $<500$ & 200 \\
\hline Farm B $(6 \mathrm{~km} \mathrm{SW})$ & July & $<500$ & 300 & 700 & $<100$ & 1,200 & 1,600 \\
\hline \multirow[t]{2}{*}{ Farm B' (8 km SW) } & July & $<500$ & 100 & 200 & $<100$ & 2,700 & 2,200 \\
\hline & October & $<500$ & 100 & 1,000 & $<100$ & 400 & 1,100 \\
\hline \multirow[t]{2}{*}{ Farm C (10 km SE) } & July & $<500$ & 900 & 800 & $<100$ & 1,200 & 1,900 \\
\hline & October & $<500$ & 800 & 1,600 & $<100$ & - & 600 \\
\hline \multirow[t]{2}{*}{ Farm D (15 km NW) } & July & $<500$ & 500 & 1,900 & $<100$ & 1,500 & 2,600 \\
\hline & October & $<500$ & 200 & 1,800 & $<100$ & $<500$ & 200 \\
\hline \multirow[t]{2}{*}{ Farm H (6 km NE) } & July & $<500$ & 900 & 800 & $<100$ & 1,400 & 1,300 \\
\hline & October & $<500$ & 200 & 800 & $<100$ & 800 & 1,400 \\
\hline
\end{tabular}

$<$ means that the value is less than or equal to the detection limit or a summation or average value in which one of the components was a $<$ value. 
APPENDIX C

1969 TABLES 
Table C-1. 1969 Background and Source Radiation Levels at the Laboratory Perimeter (mR/week)

\begin{tabular}{|c|c|c|c|c|c|c|c|c|c|c|c|c|c|c|}
\hline \multirow[t]{3}{*}{ Station: } & \multicolumn{2}{|c|}{ P-2 } & \multicolumn{2}{|l|}{ P-4 } & \multicolumn{2}{|c|}{ P-7 } & \multirow{2}{*}{\multicolumn{3}{|c|}{$\begin{array}{c}\text { P.9 } \\
\text { Northeast Perimeter }\end{array}$}} & \multicolumn{3}{|c|}{ S-13 } & \multicolumn{2}{|l|}{0.6} \\
\hline & \multicolumn{2}{|c|}{ Northwest Perimeter } & \multicolumn{2}{|c|}{ Southwest Perimeter } & \multicolumn{2}{|c|}{ Southeast Perimeter } & & & & \multicolumn{3}{|c|}{ On-site } & \multicolumn{2}{|c|}{ Off-site } \\
\hline & Background & Ar-41 & Background & Ar-41 & Background & Ar-41 & Background & Ar-41 & Source & Background & Ar -41 & Source & Background & Ar-41 \\
\hline January & 1.7 & 0.05 & 1.7 & 0.01 & 1.7 & 0.04 & 1.6 & 0.05 & 1.2 & 1.7 & 0.08 & 0.68 & 1.5 & 0.01 \\
\hline February & 1.6 & 0.04 & 1.5 & - & 1.6 & 0.14 & 1.5 & 0.05 & 1.3 & 1.6 & 0.11 & 0.70 & 1.4 & - \\
\hline March & 1.6 & 0.00 & 1.5 & 0.0 & 1.6 & 0.20 & 1.4 & 0.00 & 1.4 & 1.5 & 0.00 & 0.76 & 1.4 & 0.00 \\
\hline April & 1.5 & - & 1.6 & - & 1.7 & - & 1.5 & - & 1.5 & 1.6 & - & 0.82 & 1.5 & - \\
\hline May & 1.6 & - & 1.6 & - & 1.7 & 0.01 & 1.5 & 0.03 & 1.6 & 1.6 & 0.05 & 0.91 & 1.5 & - \\
\hline June & 1.8 & 0.43 & 1.9 & 0.0 & 1.7 & 0.09 & 1.6 & 0.12 & 1.9 & 1.9 & 0.29 & 1.2 & 1.7 & 0.07 \\
\hline July & 1.6 & 0.00 & 1.9 & 0.0 & 1.8 & 0.00 & 1.7 & 0.00 & 2.0 & 1.9 & 0.00 & 1.2 & 1.8 & 0.00 \\
\hline August & 1.7 & 0.00 & 1.9 & 0.0 & 1.8 & 0.00 & 1.7 & 0.00 & 2.1 & 1.9 & 0.00 & 1.2 & 1.7 & 0.00 \\
\hline September & 1.8 & 0.00 & 2.0 & 0.0 & 1.9 & 0.00 & 1.8 & 0.00 & 1.9 & 1.9 & 0.00 & 1.1 & 1.8 & 0.00 \\
\hline October & 1.7 & 0.00 & 1.9 & 0.0 & 1.9 & 0.00 & 1.8 & 0.00 & 1.6 & 1.9 & 0.00 & 0.95 & 1.8 & 0.00 \\
\hline November & 1.7 & 0.00 & 1.9 & 0.0 & 1.9 & 0.00 & 1.8 & 0.00 & 1.6 & 2.0 & 0.00 & 0.92 & 1.8 & 0.00 \\
\hline December & 1.6 & $\underline{0.00}$ & $\underline{1.8}$ & $\underline{0.0}$ & 1.7 & $\underline{0.00}$ & $\underline{1.6}$ & $\underline{0.00}$ & $\underline{1.3}$ & 1.7 & $\underline{0.00}$ & $\underline{0.73}$ & 1.6 & $\underline{0.00}$ \\
\hline Average $\mathrm{mR} /$ week & 1.7 & 0.05 & 1.8 & 0.001 & 1.8 & 0.04 & 1.6 & 0.02 & 1.6 & 1.8 & 0.05 & 0.93 & 1.6 & 0.01 \\
\hline Total mR/year & 89 & 2.6 & 94 & 0.05 & 94 & 2.1 & 83 & 1.0 & 84 & 92 & 2.6 & 48 & 83 & 0.52 \\
\hline
\end{tabular}

${ }^{\mathrm{a}}$ With the creation of a new perimeter on both the east and north of the site, the yearly average for the new northeast perimeter would have been about .32 mrem/wk and $17 \mathrm{mrem} / \mathrm{yr}$. 
Table C-2. 1969 Monthly Average Gross Beta-emitting Isotope Concentrations, Air Particulate Filters (pCi/m ${ }^{3}$ )

\begin{tabular}{|c|c|c|c|c|c|c|c|c|}
\hline Month & $\begin{array}{c}\text { Gross } \\
\text { Beta } \\
\end{array}$ & ${ }^{7} \mathbf{B e}$ & ${ }^{65} \mathrm{Zn}$ & ${ }^{95} \mathrm{Zr}-\mathrm{Nb}$ & ${ }^{131} I^{a}$ & ${ }^{137} \mathrm{Cs}$ & ${ }^{140}$ Ba-La & ${ }^{144} \mathrm{Ce}$ \\
\hline January & 0.078 & 0.11 & 0.001 & 0.007 & 0.002 & 0.004 & 0.003 & 0.004 \\
\hline February & 0.066 & 0.12 & 0.002 & 0.012 & $<0.001$ & 0.004 & 0.002 & 0.006 \\
\hline March & 0.11 & 0.19 & 0.002 & 0.022 & $<0.001$ & 0.005 & 0.002 & 0.012 \\
\hline April & 0.20 & 0.33 & 0.002 & 0.056 & $<0.001$ & 0.008 & $<0.002$ & 0.059 \\
\hline May & 0.32 & 0.49 & 0.004 & 0.15 & $<0.001$ & 0.010 & $<0.002$ & 0.096 \\
\hline June & 0.37 & 0.48 & 0.004 & 0.17 & $<0.001$ & 0.009 & $<0.002$ & 0.070 \\
\hline July & 0.36 & 0.32 & 0.004 & 0.15 & $<0.001$ & $<0.005$ & $<0.002$ & 0.076 \\
\hline August & 0.52 & 0.39 & 0.004 & 0.16 & $<0.001$ & 0.011 & $<0.002$ & 0.086 \\
\hline September & 0.26 & 0.28 & 0.003 & 0.097 & $<0.001$ & 0.008 & $<0.002$ & 0.072 \\
\hline October & 0.15 & 0.17 & 0.003 & 0.048 & 0.001 & 0.0056 & 0.0022 & 0.048 \\
\hline November & 0.090 & 0.11 & 0.002 & 0.022 & 0.0015 & 0.0025 & - & 0.027 \\
\hline December & $\underline{0.090}$ & $\underline{0.098}$ & $\underline{0.001}$ & $\underline{0.014}$ & $\underline{0.001}$ & $\underline{0.0024}$ & - & $\underline{0.02}$ \\
\hline Yearly Average & 0.22 & 0.26 & 0.003 & 0.076 & $<0.001$ & $<0.006$ & $<0.002$ & 0.048 \\
\hline
\end{tabular}

${ }^{a}$ Particulate filter samples only.

$<$ means that the value is less than or equal to the detection limit or a summation or average value in which one of the components was a $<$ value. 
Table C-3. 1969 Monthly Average Gross Beta Concentrations and Total Gross Beta Activity in Precipitation

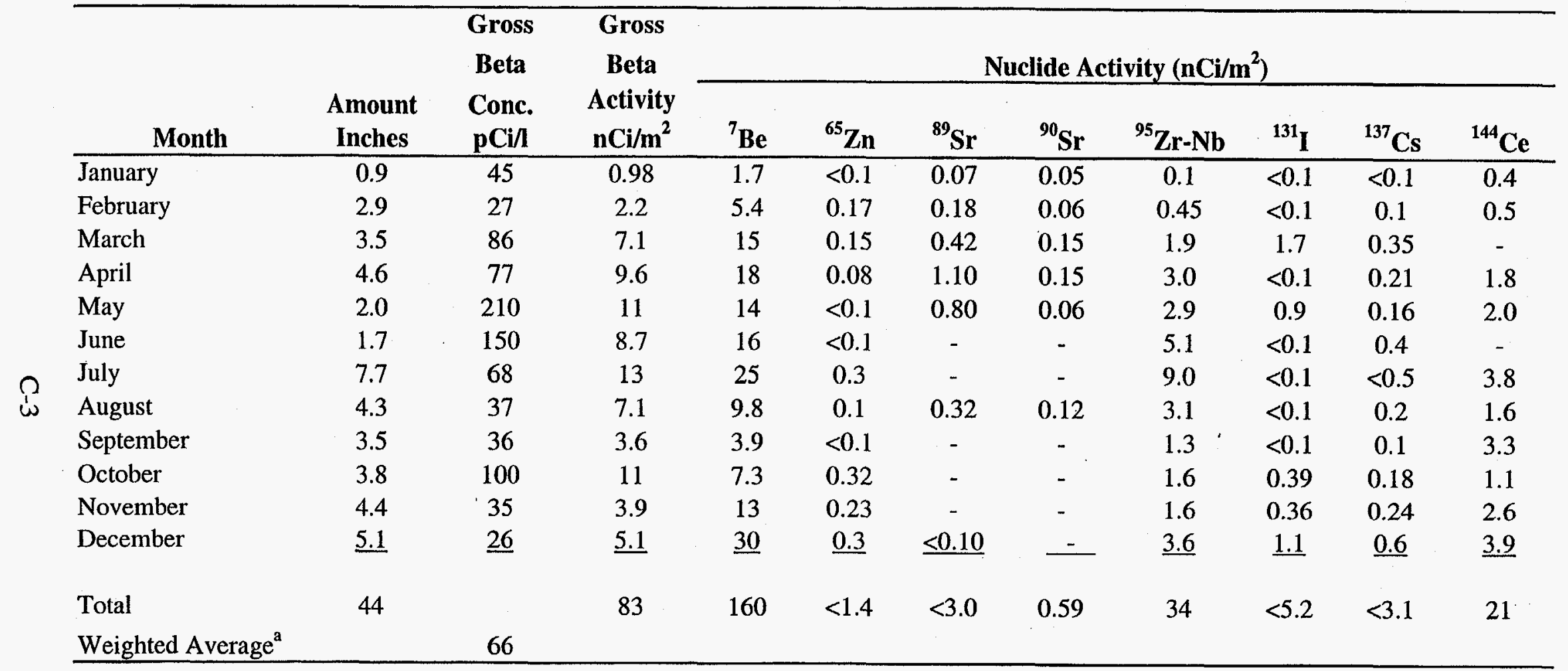

${ }^{a}$ Weighted by inches of rainfall.

$<$ means that the value is less than or equal to the detection limit or a summation or average value in which one of the components was a $<$ value. 
Table C-4. 1969 BGRR-HFBR Stack Emission

\begin{tabular}{|c|c|c|c|c|c|c|c|c|c|c|c|}
\hline \multirow[b]{2}{*}{ Month } & \multirow[b]{2}{*}{$\begin{array}{l}\text { BGRR } \\
\text { (MWd) }\end{array}$} & \multirow[b]{2}{*}{$\begin{array}{c}\text { HFBR } \\
\text { (MWd) }\end{array}$} & \multirow[b]{2}{*}{$\begin{array}{c}\text { Air volume, } \\
\mathbf{m}^{\mathbf{3}}\end{array}$} & \multicolumn{2}{|c|}{$\begin{array}{c}\text { Tritiated } \\
\text { Water Vapor }\end{array}$} & \multicolumn{2}{|c|}{${ }^{131} I$} & \multicolumn{2}{|c|}{${ }^{41} \mathrm{Ar}$} & \multicolumn{2}{|c|}{$\begin{array}{c}\text { Particulate } \\
\text { Gross Beta Activity }\end{array}$} \\
\hline & & & & $\begin{array}{c}\text { Amount } \\
\mathbf{C i}\end{array}$ & $\begin{array}{c}\text { Conc. } \\
\mathrm{pCi} / \mathrm{m}^{3}\end{array}$ & $\mathbf{m C i}$ & pCi $/ \mathrm{m}^{3}$ & $\mathbf{C i}$ & $\mathrm{pCi} / \mathrm{m}^{3}$ & $\mathbf{C i}$ & pCi $/ \mathbf{m}^{3}$ \\
\hline January & 59 & 857 & $5.2 \mathrm{E}+07$ & 32 & $6.2 \mathrm{E}+05$ & 2.40 & $4.6 \mathrm{E}+01$ & $5.2 \mathrm{E}+04$ & $1.0 \mathrm{E}+09$ & 2.3 & $4.4 \mathrm{E}+04$ \\
\hline February & 39 & 857 & $4.0 \mathrm{E}+07$ & 28 & $7.0 \mathrm{E}+05$ & 1.20 & $3.0 \mathrm{E}+01$ & $3.5 \mathrm{E}+04$ & $8.8 \mathrm{E}+08$ & 2.3 & $5.8 \mathrm{E}+04$ \\
\hline March & 48 & 898 & $4.4 \mathrm{E}+07$ & 30 & $6.8 \mathrm{E}+05$ & 0.90 & $2.0 \mathrm{E}+01$ & 4.1E+04 & $9.3 \mathrm{E}+08$ & 2.5 & $5.7 \mathrm{E}+04$ \\
\hline April & 0 & 887 & $1.8 \mathrm{E}+07$ & 32 & $1.8 \mathrm{E}+06$ & $<0.1$ & $<5.6 \mathrm{E}+00$ & $0.0 \mathrm{E}+00$ & $0.0 \mathrm{E}+00$ & 0.1 & $5.6 \mathrm{E}+03$ \\
\hline May & 12 & 878 & 2.1E+07 & 33 & $1.6 \mathrm{E}+06$ & 0.25 & $1.2 \mathrm{E}+01$ & 1.1E+04 & $5.2 \mathrm{E}+08$ & 1.1 & $5.2 \mathrm{E}+04$ \\
\hline June $^{a}$ & 61 & 775 & $5.4 \mathrm{E}+07$ & 36 & $6.7 \mathrm{E}+05$ & 2.0 & $3.7 \mathrm{E}+01$ & $5.3 \mathrm{E}+04$ & $9.8 \mathrm{E}+08$ & 3.8 & $7.0 \mathrm{E}+04$ \\
\hline July & 0 & 896 & $1.9 \mathrm{E}+07$ & 33 & $1.7 \mathrm{E}+06$ & $<0.10$ & $<5.3 \mathrm{E}+00$ & $0.0 \mathrm{E}+00$ & $0.0 \mathrm{E}+00$ & 0.1 & $5.3 \mathrm{E}+03$ \\
\hline August & 0 & 845 & $1.9 \mathrm{E}+07$ & 26 & $1.4 \mathrm{E}+06$ & $<0.10$ & $<5.3 \mathrm{E}+00$ & $0.0 \mathrm{E}+00$ & $0.0 \mathrm{E}+00$ & 0.1 & $5.3 \mathrm{E}+03$ \\
\hline September & 0 & 826 & $1.8 \mathrm{E}+07$ & 24 & $1.3 \mathrm{E}+06$ & $<0.10$ & $<5.6 \mathrm{E}+00$ & $0.0 \mathrm{E}+00$ & $0.0 \mathrm{E}+00$ & 0.1 & $5.6 \mathrm{E}+03$ \\
\hline October & 0 & 813 & $1.9 \mathrm{E}+07$ & 37 & $1.9 \mathrm{E}+06$ & $<0.10$ & $<5.3 \mathrm{E}+00$ & $0.0 \mathrm{E}+00$ & $0.0 \mathrm{E}+00$ & 0.1 & $5.3 \mathrm{E}+03$ \\
\hline November & 0 & 878 & $1.8 \mathrm{E}+07$ & 34 & $1.9 \mathrm{E}+06$ & $<0.10$ & $<5.6 \mathrm{E}+00$ & $0.0 \mathrm{E}+00$ & $0.0 \mathrm{E}+00$ & 0.1 & $5.6 \mathrm{E}+03$ \\
\hline December & $\underline{0}$ & 738 & $\underline{1.9 \mathrm{E}+07}$ & $\underline{32}$ & $\underline{1.7 \mathrm{E}+06}$ & $\leq 0.10$ & $\underline{5.3 \mathrm{E}+00}$ & $\underline{0.0 \mathrm{E}+00}$ & $\underline{0.0 \mathrm{E}+00}$ & $\underline{0.1}$ & $\underline{5.3 \mathrm{E}+03}$ \\
\hline Annual total & 219 & 10,148 & $3.4 \mathrm{E}+08$ & 380 & & $<7.6$ & & $1.9 \mathrm{E}+05$ & & 13 & \\
\hline Average & & & & & $1.3 \mathrm{E}+06$ & & $<1.5 E+01$ & & $3.6 \mathrm{E}+08$ & & $2.7 \mathrm{E}+04$ \\
\hline
\end{tabular}

${ }^{\mathrm{a}}$ Final month of BGRR operation at measurable power levels.

$<$ means that the value is less than or equal to the detection limit or a summation or average value in which one of the components was a $<$ value. 
Table C-5. 1969 Clarifier. Flow, Gross Beta, Tritiated Water, ${ }^{90} \mathrm{Sr}$, and ${ }^{137} \mathrm{Cs}$ Amounts and Concentrations

\begin{tabular}{|c|c|c|c|c|c|c|c|c|c|}
\hline \multirow[b]{2}{*}{ Month } & \multirow[b]{2}{*}{$\begin{array}{l}\text { Flow } \\
10^{9} 1\end{array}$} & \multicolumn{2}{|c|}{ Gross Beta $^{\mathrm{a}}$} & \multicolumn{2}{|c|}{ Tritiated Water } & \multicolumn{2}{|c|}{${ }^{90} \mathrm{Sr}$} & \multicolumn{2}{|c|}{${ }^{137} \mathrm{Cs}$} \\
\hline & & $\begin{array}{l}\text { Conc. } \\
\text { pCi// }\end{array}$ & $\underset{\text { mCi }}{\text { Amount }}$ & $\begin{array}{l}\text { Conc. } \\
\text { pCi// }\end{array}$ & $\begin{array}{c}\text { Amount } \\
\mathbf{m C i}\end{array}$ & $\begin{array}{l}\text { Conc. } \\
\text { pCi/l }\end{array}$ & $\begin{array}{c}\text { Amount } \\
\text { mCi }\end{array}$ & $\begin{array}{l}\text { Conc. } \\
\text { pCi// }\end{array}$ & $\begin{array}{c}\text { Amount } \\
\text { mCi }\end{array}$ \\
\hline January & 0.095 & 9 & 0.86 & 1,200 & 110 & 0.30 & 0.03 & 0.9 & 0.09 \\
\hline February & 0.083 & 23 & 1.9 & 1,500 & 130 & 0.50 & 0.04 & 2.0 & 0.17 \\
\hline March & 0.088 & 31 & 2.7 & 5,200 & 460 & 0.60 & 0.05 & 1.2 & 0.10 \\
\hline April & 0.097 & 25 & 2.4 & 2,900 & 280 & 0.30 & 0.03 & 0.7 & 0.07 \\
\hline May & 0.12 & 17 & 2.0 & 12,000 & 1,400 & 0.29 & 0.03 & 1.0 & 0.12 \\
\hline June & 0.13 & 23 & 3.0 & 4,700 & 610 & - & - & 0.4 & 0.05 \\
\hline July & 0.16 & 10 & 1.6 & 17,000 & 2,700 & 0.34 & 0.05 & 1.0 & 0.16 \\
\hline August & 0.19 & 17 & 3.2 & 8,200 & 1,600 & 0.54 & 0.10 & 0.4 & 0.08 \\
\hline September & 0.16 & 8 & 1.3 & 2,700 & 430 & 0.40 & 0.06 & 1.0 & 0.16 \\
\hline October & 0.15 & 6.6 & 1.0 & 34,000 & 5,100 & 0.35 & 0.05 & 0.3 & 0.05 \\
\hline November & 0.18 & 12 & 2.2 & 20,000 & 3,600 & 1.0 & 0.18 & 0.8 & 0.14 \\
\hline December & $\underline{0.13}$ & $\underline{12}$ & 1.6 & $\underline{7,300}$ & $\underline{950}$ & $\underline{0.38}$ & $\underline{0.05}$ & $\underline{0.4}$ & $\underline{0.05}$ \\
\hline Total & 1.6 & & 24 & & 17,000 & & 0.67 & & 1.2 \\
\hline Weighted Average ${ }^{b}$ & & 15 & & 11,000 & & 0.42 & & 0.75 & \\
\hline
\end{tabular}

${ }^{a}$ Includes gamma-only emitters and does not include tritiated water.

${ }^{b}$ Weighted average concentration $=$ total amount $(\mathrm{mCi}) /$ total flow $\left(10^{9} 1\right)$. 
Table C-6. 1969 Chlorinating Plant. Flow, Gross Beta, Tritiated Water, ${ }^{90} \mathrm{Sr}$, and ${ }^{137} \mathrm{Cs}$ Amounts and Concentrations

\begin{tabular}{|c|c|c|c|c|c|c|c|c|c|}
\hline \multirow[b]{2}{*}{ Month } & \multirow[b]{2}{*}{$\begin{array}{l}\text { Flow } \\
10^{9} 1 \\
\end{array}$} & \multicolumn{2}{|c|}{ Gross Beta $^{a}$} & \multicolumn{2}{|c|}{ Tritiated Water } & \multicolumn{2}{|c|}{${ }^{90} \mathrm{Sr}$} & \multicolumn{2}{|c|}{${ }^{137} \mathrm{Cs}$} \\
\hline & & $\begin{array}{l}\text { Conc. } \\
\text { pCi// }\end{array}$ & $\begin{array}{c}\text { Amount } \\
\mathbf{m C i}\end{array}$ & $\begin{array}{l}\text { Conc. } \\
\text { pCi/l }\end{array}$ & $\begin{array}{c}\text { Amount } \\
\mathrm{mCi}\end{array}$ & $\begin{array}{l}\text { Conc. } \\
\text { pCi// }\end{array}$ & $\begin{array}{c}\text { Amount } \\
\text { mCi }\end{array}$ & $\begin{array}{l}\text { Conc. } \\
\text { pCi// }\end{array}$ & $\begin{array}{c}\text { Amount } \\
\text { mCi }\end{array}$ \\
\hline January & 0.082 & 12 & 0.98 & 1,600 & 130 & 0.5 & 0.04 & 5.0 & 0.41 \\
\hline February & 0.077 & 15 & 1.2 & 1,800 & 140 & 0.5 & 0.04 & 7.0 & 0.54 \\
\hline March & 0.076 & 24 & 1.8 & 5,500 & 420 & 1.0 & 0.076 & 9.0 & 0.68 \\
\hline April & 0.074 & 13 & 0.96 & 2,500 & 190 & 0.8 & 0.067 & 5.0 & 0.37 \\
\hline May & 0.099 & 17 & 1.7 & 14,000 & 1,400 & 0.7 & 0.069 & 6.0 & 0.59 \\
\hline June & 0.12 & 13 & 1.6 & 4,500 & 540 & - & - & 3.0 & 0.36 \\
\hline July & 0.13 & 16 & 2.1 & 22,000 & 2,900 & 0.6 & 0.078 & 4.0 & 0.52 \\
\hline August & 0.14 & 10 & 1.4 & 9,200 & 1,300 & 0.71 & 0.098 & 2.0 & 0.28 \\
\hline September & 0.13 & 12 & 1.6 & 2,400 & 310 & 0.9 & $0.1,20$ & 4.0 & 0.52 \\
\hline October & 0.13 & 10 & 1.3 & 33,000 & 4,300 & 0.48 & 0.065 & 2.4 & 0.31 \\
\hline November & 0.14 & 9.3 & 1.3 & 19,000 & 2,700 & 0.7 & 0.098 & 3.1 & 0.42 \\
\hline December & $\underline{0.092}$ & $\underline{11}$ & $\underline{1.0}$ & $\underline{9,100}$ & $\underline{840}$ & $\underline{0.8}$ & 0.074 & $\underline{4.0}$ & $\underline{0.37}$ \\
\hline Total & 1.3 & & 17 & & 15,000 & & 0.83 & & 5.4 \\
\hline Weighted Average $^{b}$ & & 13 & & 12,000 & & 0.64 & & 4.1 & \\
\hline
\end{tabular}

${ }^{a}$ Includes gamma-only emitters and does not include tritiated water.

${ }^{\mathrm{b}}$ Weighted average concentration $=$ total amount $(\mathrm{mCi}) /$ total flow $\left(10^{9} \mathrm{l}\right)$. 
Table C-7. 1969 "M" (Former Perimeter). Flow, Gross Beta, Tritiated Water, ${ }^{90} \mathrm{Sr}$, and ${ }^{137}$ Cs Amounts and Concentrations

\begin{tabular}{|c|c|c|c|c|c|c|c|c|c|}
\hline \multirow[b]{2}{*}{ Month } & \multirow[b]{2}{*}{$\begin{array}{c}\text { Flow } \\
10^{9} 1\end{array}$} & \multicolumn{2}{|c|}{ Gross Beta $^{a}$} & \multicolumn{2}{|c|}{ Tritiated Water } & \multicolumn{2}{|c|}{${ }^{90} \mathrm{Sr}$} & \multicolumn{2}{|c|}{${ }^{137} \mathrm{Cs}$} \\
\hline & & $\begin{array}{l}\text { Conc. } \\
\text { pCi/l }\end{array}$ & $\begin{array}{c}\text { Amount } \\
\text { mCi }\end{array}$ & $\begin{array}{l}\text { Conc. } \\
\text { pCi/l }\end{array}$ & $\begin{array}{c}\text { Amount } \\
\mathbf{m C i}\end{array}$ & $\begin{array}{l}\text { Conc. } \\
\text { pCi// }\end{array}$ & $\begin{array}{c}\text { Amount } \\
\text { mCi }\end{array}$ & $\begin{array}{l}\text { Conc. } \\
\mathrm{pCi} / \mathrm{l}\end{array}$ & $\begin{array}{c}\text { Amount } \\
\text { mCi }\end{array}$ \\
\hline January & 0.097 & 9 & 0.87 & 1,800 & 170 & 0.8 & 0.078 & 6.0 & 0.58 \\
\hline February & 0.09 & 12 & 1.1 & 1,800 & 160 & 0.6 & 0.054 & 6.0 & 0.54 \\
\hline March & 0.095 & 20 & 1.9 & 5,300 & 500 & 0.8 & 0.076 & 7.0 & 0.67 \\
\hline April & 0.097 & 11 & 1.1 & 2,200 & 210 & 0.9 & 0.087 & 5.0 & 0.49 \\
\hline May & 0.11 & 14 & 1.5 & 12,000 & 1,300 & 0.66 & 0.073 & 5.0 & 0.55 \\
\hline June & 0.13 & 13 & 1.7 & 4,600 & 600 & 1.1 & 0.14 & 3.0 & 0.39 \\
\hline July & 0.11 & 9 & 0.99 & 18,000 & 200 & 0.92 & 0.10 & 5.0 & 0.55 \\
\hline August & 0.14 & 12 & 1.7 & 8,400 & 1,200 & 0.93 & 0.13 & 3.0 & 0.42 \\
\hline September & 0.12 & 11 & 1.3 & 2,700 & 3,200 & 1.0 & 0.12 & 4.0 & 0.48 \\
\hline October & 0.12 & 9.8 & 1.2 & 38,000 & 4,400 & 0.62 & 0.074 & 3.1 & 0.37 \\
\hline November & 0.14 & 11 & 1.5 & 19,000 & 2,700 & 0.86 & 0.12 & 3.1 & 0.43 \\
\hline December & $\underline{0.12}$ & 11 & 1.3 & $\underline{8,000}$ & 960 & $\underline{0.84}$ & 0.10 & 3.6 & 0.43 \\
\hline Total & 1.4 & & 16 & & 15,000 & & 1.2 & & 5.9 \\
\hline Weighted Average ${ }^{b}$ & & 12 & & 11,000 & & 0.86 & & 4.2 & \\
\hline
\end{tabular}

${ }^{a}$ Includes gamma-only emitters and does not include tritiated water.

${ }^{b}$ Weighted average concentration $=$ total amount $(\mathrm{mCi}) /$ total flow $\left(10^{9} \mathrm{l}\right)$. 
Table C-8. 1969 "Q" (Current Perimeter). Flow, Gross Beta, Tritiated Water, ${ }^{90} \mathrm{Sr}$, and ${ }^{137} \mathrm{Cs}$ Amounts and Concentrations

\begin{tabular}{|c|c|c|c|c|c|c|c|c|c|}
\hline \multirow[b]{2}{*}{ Month } & \multirow[b]{2}{*}{$\begin{array}{c}\text { Flow } \\
10^{9} 1\end{array}$} & \multicolumn{2}{|c|}{ Gross Beta $^{a}$} & \multicolumn{2}{|c|}{ Tritiated Water } & \multicolumn{2}{|c|}{${ }^{90} \mathrm{Sr}$} & \multicolumn{2}{|c|}{${ }^{137} \mathrm{Cs}$} \\
\hline & & $\begin{array}{l}\text { Conc. } \\
\text { pCi// }\end{array}$ & $\begin{array}{c}\text { Amount } \\
\text { mCi }\end{array}$ & $\begin{array}{l}\text { Conc. } \\
\text { pCi/l }\end{array}$ & $\underset{\text { mCi }}{\text { Amount }}$ & $\begin{array}{l}\text { Conc. } \\
\text { pCi/l }\end{array}$ & $\begin{array}{c}\text { Amount } \\
\text { mCi }\end{array}$ & $\begin{array}{l}\text { Conc. } \\
\text { pCi/l }\end{array}$ & $\begin{array}{c}\text { Amount } \\
\text { mCi }\end{array}$ \\
\hline January & 0.073 & 11 & 0.80 & 1,500 & 110 & 0.7 & 0.05 & 5.0 & 0.37 \\
\hline February & 0.05 & 12 & 2.00 & 2,200 & 110 & 0.4 & 0.020 & 7.0 & 0.35 \\
\hline March & 0.054 & 21 & 1.10 & 5,200 & 280 & 0.9 & 0.049 & 7.0 & 0.38 \\
\hline April & 0.08 & 13 & 1.00 & 1,900 & 150 & 0.9 & 0.072 & 5.0 & 0.40 \\
\hline May & 0.086 & 23 & 2.00 & 9,600 & 830 & 0.66 & 0.057 & 7.0 & 0.60 \\
\hline June & 0.046 & 15 & 0.69 & 4,400 & 200 & 0.9 & 0.041 & 6.0 & 0.28 \\
\hline July & 0.024 & 13 & 0.31 & 16,000 & 380 & 0.53 & 0.013 & 6.0 & 0.14 \\
\hline August & 0.069 & 10 & 0.69 & 7,000 & 480 & 1.0 & 0.069 & 4.0 & 0.28 \\
\hline September & 0.045 & 10 & 0.45 & 2,400 & 110 & 1.2 & 0.054 & 4.0 & 0.18 \\
\hline October & 0.042 & 8.5 & 0.36 & 34,000 & 1,400 & 0.79 & 0.033 & 6.0 & 0.25 \\
\hline November & 0.061 & 15 & 0.92 & 14,000 & 850 & 0.95 & 0.058 & 4.0 & 0.24 \\
\hline December & $\underline{0.084}$ & $\underline{11}$ & 0.92 & $\underline{5,900}$ & 500 & $\underline{1.0}$ & 0.084 & $\underline{2.0}$ & 0.17 \\
\hline Total & 0.7 & & 9.8 & & 5,400 & & 0.56 & & 3.7 \\
\hline Weighted Average ${ }^{b}$ & & 14 & & 7,700 & & 0.80 & & 5.3 & \\
\hline
\end{tabular}

ancludes gamma-only emitters and does not include tritiated water.

${ }^{b}$ Weighted average concentration $=$ total amount $(\mathrm{mCi}) /$ total flow $\left(10^{9} 1\right)$. 
Table C-9. 1969 Monthly Downstream and Control Location Water Grab Samples. Gross Beta and Tritiated Water

\begin{tabular}{|c|c|c|c|c|c|c|c|c|c|c|c|c|c|c|}
\hline \multirow[b]{2}{*}{ Month } & \multicolumn{8}{|c|}{ Downstream Locations } & \multicolumn{5}{|c|}{ Control Locations } & \multirow[b]{2}{*}{$\mathbf{R}^{\mathbf{b}}$} \\
\hline & $\mathbf{A}$ & B & $\mathrm{C}$ & D & $\mathbf{K}$ & $\mathbf{L}$ & $\mathbf{M}^{\mathrm{a}}$ & $\mathbf{Q}^{\mathrm{a}}$ & $\mathbf{E}$ & $\mathbf{F}$ & H & I & $\mathbf{J}$ & \\
\hline \multicolumn{15}{|c|}{ Gross Beta (pCi//) } \\
\hline January & $\mathrm{c}$ & $\mathrm{c}$ & c & c & c & c & c & c & c & $\mathrm{c}$ & c & $\mathrm{c}$ & c & - \\
\hline February & 5.0 & 4.0 & 4.0 & 3.0 & 28 & 31 & 9.0 & 12 & 6.0 & - & 3.0 & 10 & 3.0 & - \\
\hline March & 3.0 & 4.0 & 2.0 & 7.0 & 16 & 18 & 10 & 16 & 6.0 & - & 5.0 & 9.0 & 3.0 & - \\
\hline April & 6.0 & 3.0 & 4.0 & 3.0 & 9.0 & 11 & 11 & 8.0 & 3.0 & 8.0 & 1.0 & 7.0 & 3.0 & - \\
\hline May & 6.0 & 5.0 & 6.0 & 4.0 & 26 & 29 & 25 & 21 & 27 & - & 3.0 & 7.0 & 6.0 & - \\
\hline June & 8.0 & 3.0 & 9.0 & 5.0 & 17 & 12 & 14 & 11 & 8.0 & 9.0 & - & 1.0 & 8.0 & - \\
\hline July & 4.0 & 2.0 & 6.0 & 5.0 & 12 & 12 & 15 & 10 & - & 10 & - & - & 6.0 & 3.0 \\
\hline August & 5.0 & 4.0 & 8.0 & 6.0 & 10 & 11 & 11 & 8.0 & 6.0 & 8.0 & 2.0 & 5.0 & 4.0 & 4.0 \\
\hline September & 5.0 & 2.0 & 3.0 & 3.0 & 10 & 9.0 & 10 & 6.0 & 9.0 & 4.0 & 2.0 & 4.0 & 4.0 & 4.0 \\
\hline October & 6.0 & 4.0 & 5.0 & 9.0 & 14 & 12 & 10 & 9.0 & 5.0 & 6.0 & 2.0 & 7.0 & 4.0 & 5.0 \\
\hline November & 5.0 & 4.0 & 3.0 & 4.0 & 9.0 & 7.0 & 11 & 15 & 5.0 & 4.0 & 2.0 & 4.0 & 3.0 & 5.0 \\
\hline December & $\underline{7.0}$ & 4.0 & $\underline{4.0}$ & $\underline{6.0}$ & $\underline{8.0}$ & 10 & 9.0 & $\underline{8.0}$ & $\underline{6.0}$ & $\underline{5.0}$ & 4.0 & $\underline{8.0}$ & 4.0 & $\underline{15}$ \\
\hline Yearly Average & 5.5 & 4.0 & 5.0 & 5.0 & 14 & 15 & 12 & 11 & 8.1 & 6.8 & 2.7 & 6.2 & 4.4 & 6.0 \\
\hline \multicolumn{15}{|c|}{ Tritiated Water (pCi/l) } \\
\hline January & $\mathrm{c}$ & c & c & c & $\mathrm{c}$ & $\mathrm{c}$ & $\mathrm{c}$ & c & c & c & c & $\mathrm{c}$ & c & $\mathrm{c}$ \\
\hline February & $<1,000$ & $<1,000$ & $<1,000$ & $<1,000$ & 1,000 & 1,000 & 2,000 & 3,000 & $<1,000$ & - & $<1,000$ & $<1,000$ & $<1,000$ & - \\
\hline March & 2,000 & $<1,000$ & $<1,000$ & $<1,000$ & $<1,000$ & 1,000 & 3,000 & 2,000 & $<1,000$ & - & 2,000 & $<1,000$ & 2,000 & - \\
\hline April & 2,000 & $<1,000$ & $<1,000$ & $<1,000$ & $<1,000$ & 1,000 & $<1,000$ & 1,000 & 1,000 & $<1,000$ & $<1,000$ & $<1,000$ & $<1,000$ & - \\
\hline May & 3,000 & $<1,000$ & $<1,000$ & $<1,000$ & - & - & 35,000 & 220,000 & $<1,000$ & - & $<1,000$ & $<1,000$ & $<1,000$ & - \\
\hline June & 2,000 & $<1,000$ & $<1,000$ & $<1,000$ & 2,000 & $<1,000$ & 3,000 & $3 ; 000$ & 1,000 & $<1,000$ & - & $<1,000$ & $<1,000$ & - \\
\hline July & $<1,000$ & $<1,000$ & 1,000 & $<1,000$ & $<1,000$ & 1,000 & 5,000 & 9,000 & - & $<1,000$ & - & - & $<1,000$ & $<1,000$ \\
\hline August & 3,000 & 1,000 & 1,000 & $<1,000$ & 3,000 & 3,000 & 3,000 & 4,000 & $<1,000$ & $<1,000$ & $<1,000$ & $<1,000$ & 1,900 & $<1,000$ \\
\hline September & $<1,000$ & $<1,000$ & $<1,000$ & $<1,000$ & 2,000 & $<1,000$ & 2,000 & 1,000 & - & - & - & - & - & $<1,000$ \\
\hline October & 11,000 & 6,000 & $<1,000$ & $<1,000$ & 2,600 & 3,600 & 38,000 & 39,000 & $<1,000$ & $<1,000$ & $<1,000$ & $<1,000$ & 1,900 & $<1,000$ \\
\hline November & $<1,000$ & $<1,000$ & $<1,000$ & $<1,000$ & $<1,000$ & $<1,000$ & 19,000 & 14,000 & $<1,000$ & $<1,000$ & $<1,000$ & $<1,000$ & $<1,000$ & $<1,000$ \\
\hline December & $\underline{4,000}$ & $\underline{3,000}$ & $\underline{2,000}$ & 1,000 & $\underline{2,000}$ & 3,000 & $\underline{8,000}$ & $\underline{6,000}$ & $\leq 1,000$ & $\underline{1,000}$ & $\leq 1,000$ & $\leq 1,000$ & $\leq 1,000$ & $\underline{1,000}$ \\
\hline Yearly Average & $<2,800$ & $<1,600$ & $<1,100$ & $<1,100$ & $<1,800$ & $<1,700$ & $<11,000$ & 27,000 & $<1,000$ & $<1,000$ & $<1,100$ & $<1,000$ & $<1,300$ & $<1,000$ \\
\hline
\end{tabular}

${ }^{\mathrm{a}}$ Continuous sample.

'Riverhead USGS Gauging Station.

${ }^{\mathrm{c}}$ Not collected due to low input concentrations and adverse weather.

$<$ means that the value is less than or equal to the detection limit or a summation or average value in which one of the components was a $<$ value. 
Table C-10. 1969 Bottom Sediment Sample Concentrations

\begin{tabular}{|c|c|c|c|c|c|c|c|}
\hline Month & $\begin{array}{c}\text { Peconic } \\
\text { Location }\end{array}$ & $\begin{array}{l}{ }^{60} \mathrm{Co} \\
\mathrm{pCi} / \mathrm{g} \\
\text { (dry) }\end{array}$ & $\begin{array}{l}{ }^{65} \mathrm{Zn} \\
\mathrm{pCi} / \mathrm{g} \\
(\mathrm{dry})\end{array}$ & $\begin{array}{c}{ }^{95} \mathrm{Zr}-\mathrm{Nb} \\
\mathrm{pCi} / \mathrm{g} \\
\text { (dry) }\end{array}$ & $\begin{array}{l}{ }^{137} \mathrm{Cs} \\
\mathrm{pCi} / \mathrm{g} \\
\text { (dry) }\end{array}$ & $\begin{array}{c}\mathrm{U} \\
\mathrm{pCi} / \mathrm{g} \\
\text { (dry) }\end{array}$ & $\begin{array}{c}\text { Th } \\
\mathrm{pCi} / \mathrm{g} \\
\text { (dry) }\end{array}$ \\
\hline \multirow[t]{8}{*}{ November } & $\mathrm{K}$ & - & - & - & - & - & - \\
\hline & $\mathrm{L}$ & 0.06 & 0.02 & - & 0.19 & 0.40 & $0: 50$ \\
\hline & M & 0.89 & - & - & 1.6 & - & - \\
\hline & $\mathrm{Q}$ & 0.05 & 0.02 & - & 0.61 & 0.29 & 0.35 \\
\hline & A & - & 0.09 & 0.04 & 0.46 & 0.15 & 0.11 \\
\hline & B & - & 0.13 & - & 0.18 & 0.39 & 0.56 \\
\hline & $\mathrm{C}$ & - & - & - & - & - & - \\
\hline & D & - & - & - & - & - & - \\
\hline
\end{tabular}


Table C-11. 1969 Concentrations of Gamma-emitting Nuclides in Animals and Vegetation Obtained from the Peconic River

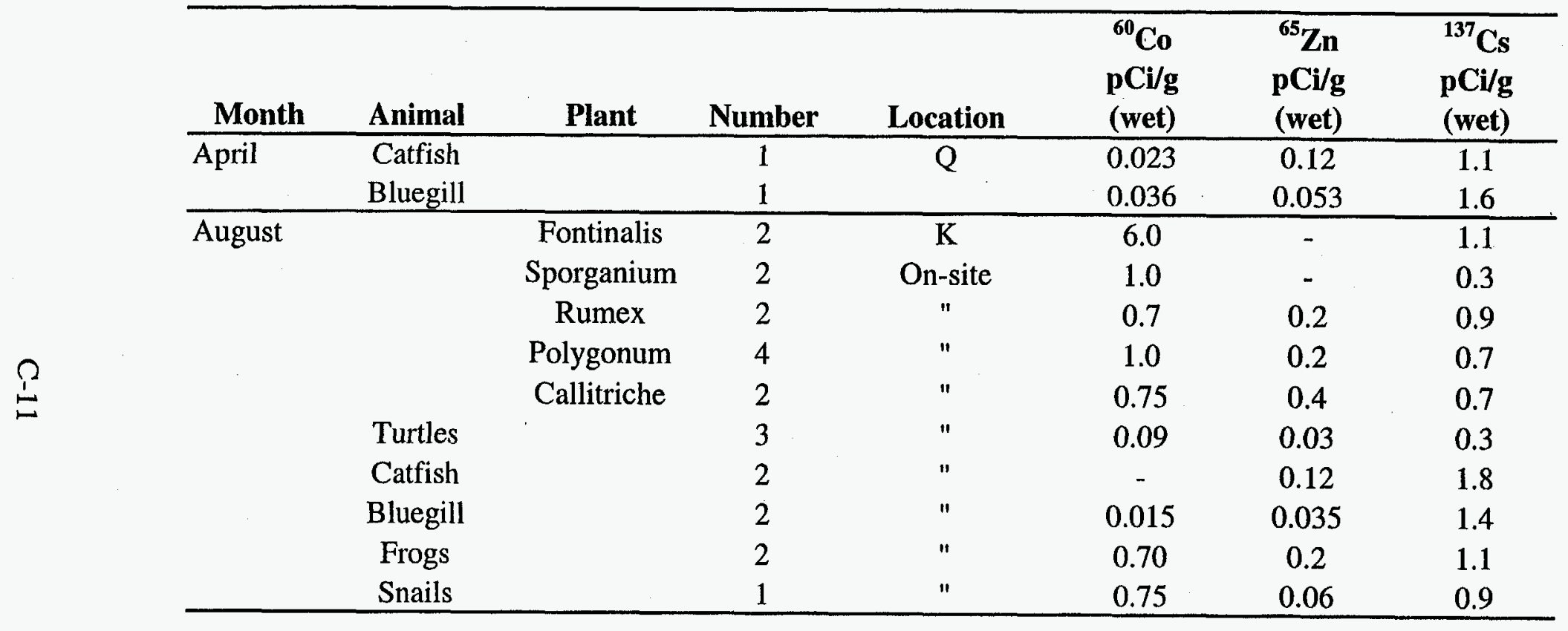


Table C-12. 1969 Gross Beta and Tritiated Water Concentrations in Potable and Cooling Water Supply Wells

\begin{tabular}{|c|c|c|c|c|c|c|c|c|c|c|c|c|}
\hline Month & Well 1 & Well 2 & Well 3 & Well 4 & Well 5 & Well 6 & Well 7 & Well 101 & Well 102 & Well 103 & Well 104 & Well 105 \\
\hline \multicolumn{13}{|c|}{ Gross Beta $(\mathrm{pCi} /)$} \\
\hline January & 1.0 & 1.0 & 1.2 & 2.3 & 1.6 & 1.5 & 1.2 & 1.1 & $<1.0$ & 2.8 & $<1.0$ & - \\
\hline February & 1.3 & 2.1 & $<1.0$ & 1.6 & $<1.0$ & $<1.0$ & 1.1 & 1.4 & $<1.0$ & 1.6 & $<1.0$ & 1.9 \\
\hline March & 2.2 & $<1.0$ & 2.0 & 1.3 & 1.1 & 1.1 & - & 1.2 & 1.8 & 1.1 & - & - \\
\hline April & 1.8 & $<1.0$ & $<1.0$ & 4.5 & 1.2 & 1.5 & 1.3 & $<1.0$ & $<1.0$ & 2.4 & 1.4 & 1.4 \\
\hline May & 1.5 & $<1.0$ & 1.7 & 2.1 & 1.1 & 1.3 & $<1.0$ & 1.5 & 2.4 & 2.6 & 7.4 & 4.6 \\
\hline June & 1.3 & 1.1 & $<1.0$ & 2.0 & - & 3.7 & 4.8 & - & - & - & 1.4 & 1.7 \\
\hline July & 4.7 & 3.3 & 1.7 & 2.9 & 1.8 & 4.0 & 1.6 & - & 2.1 & - & 1.4 & 1.6 \\
\hline August & $<1.0$ & 4.2 & 1.4 & 1.4 & 1.9 & 1.4 & $<1.0$ & - & 4.0 & - & 2.3 & 1.4 \\
\hline September & $<1.0$ & 5.4 & 2.9 & 1.5 & 1.1 & 1.4 & 1.1 & - & - & - & 1.1 & 1.5 \\
\hline October & 0.8 & 0.7 & 0.4 & 1.2 & 1.0 & 0.5 & $<0.5$ & - & $<0.5$ & - & 0.53 & 0.7 \\
\hline November & 1.7 & 2.5 & 0.87 & 5.4 & 2.0 & 2.1 & 0.85 & 1.6 & 0.64 & - & 1.6 & 2.6 \\
\hline December & $\underline{1.5}$ & $\underline{1.4}$ & $\leq 0.5$ & 1.1 & $\underline{1.6}$ & $\underline{1.9}$ & $\underline{1.0}$ & $\underline{1.2}$ & - & $\underline{2.0}$ & - & - \\
\hline Yearly Average & $<1.7$ & $<2.1$ & $<1.3$ & 2.3 & $<1.4$ & $<1.8$ & $<1.4$ & $<1.3$ & $<1.6$ & 2.1 & $<1.9$ & 1.9 \\
\hline \multicolumn{13}{|c|}{ Tritiated Water $(\mathrm{pCi} / 1)$} \\
\hline January & $<1,000$ & $<1,000$ & $<1,000$ & $<1,000$ & $<1,000$ & $<1,000$ & $<1,000$ & $<1,000$ & $<1,000$ & $<1,000$ & $<1,000$ & - \\
\hline February & $<1,000$ & $<1,000$ & $<1,000$ & $<1,000$ & $<1,000$ & 1,400 & $<1,000$ & $<1,000$ & 1,500 & $<1,000$ & $<1,000$ & $<1,000$ \\
\hline March & $<1,000$ & $<1,000$ & $<1,000$ & $<1,000$ & 1,600 & $<1,000$ & - & $<1,000$ & $<1,000$ & $<1,000$ & - & - \\
\hline April & $<1,000$ & $<1,000$ & $<1,000$ & $<1,000$ & $<1,000$ & $<1,000$ & $<1,000$ & $<1,000$ & $<1,000$ & 1,400 & 1,500 & $<1,000$ \\
\hline May & $<1,000$ & $<1,000$ & $<1,000$ & $<1,000$ & $<1,000$ & $<1,000$ & $<1,000$ & $<1,000$ & $<1,000$ & $<1,000$ & $<1,000$ & $<1,000$ \\
\hline June & $<1,000$ & $<1,000$ & $<1,000$ & $<1,000$ & - & $<1,000$ & $<1,000$ & - & - & - & 1,600 & $<1,000$ \\
\hline July & $<1,000$ & $<1,000$ & $<1,000$ & $<1,000$ & $<1,000$ & $<1,000$ & $<1,000$ & - & 2,000 & - & 1,700 & $<1,000$ \\
\hline August & $<1,000$ & $<1,000$ & $<1,000$ & $<1,000$ & $<1,000$ & $<1,000$ & $<1,000$ & - & $<1,000$ & - & $<1,000$ & $<1,000$ \\
\hline September & $<1,000$ & $<1,000$ & $<1,000$ & $<1,000$ & $<1,000$ & $<1,000$ & $<1,000$ & - & $<1,000$ & - & $<1,000$ & $<1,000$ \\
\hline October & - & - & $<1,000$ & $<1,000$ & $<1,000$ & $<1,000$ & $<1,000$ & - & $<1,000$ & - & $<1,000$ & $<1,000$ \\
\hline November & $220^{a}$ & $270^{\mathrm{a}}$ & $210^{a}$ & $100^{\mathrm{a}}$ & $750^{\mathrm{a}}$ & $280^{2}$ & $430^{2}$ & $1,100^{\mathrm{a}}$ & $390^{\mathrm{a}}$ & - & $1,200^{\mathrm{a}}$ & $250^{a}$ \\
\hline December & $\leq 1,000$ & $\leq 1,000$ & $\leq 1,000$ & $\leq 1,000$ & $\leq 1,000$ & $\leq 1,000$ & $\leq 1,000$ & $\leq 1,000$ & $\leq 1,000$ & - & - & - \\
\hline Yearly Average & $<930$ & $<940$ & $<930$ & $<930$ & $<1,100$ & $<1,000$ & $<1,000$ & $<1,100$ & $<1,100$ & $<1,100$ & $<1,200$ & $<1,000$ \\
\hline
\end{tabular}

${ }^{a}$ Analysis following enrichment.

$<$ means that the value is less than or equal to the detection limit or a summation or average value in which one of the components was a $<$ value. 


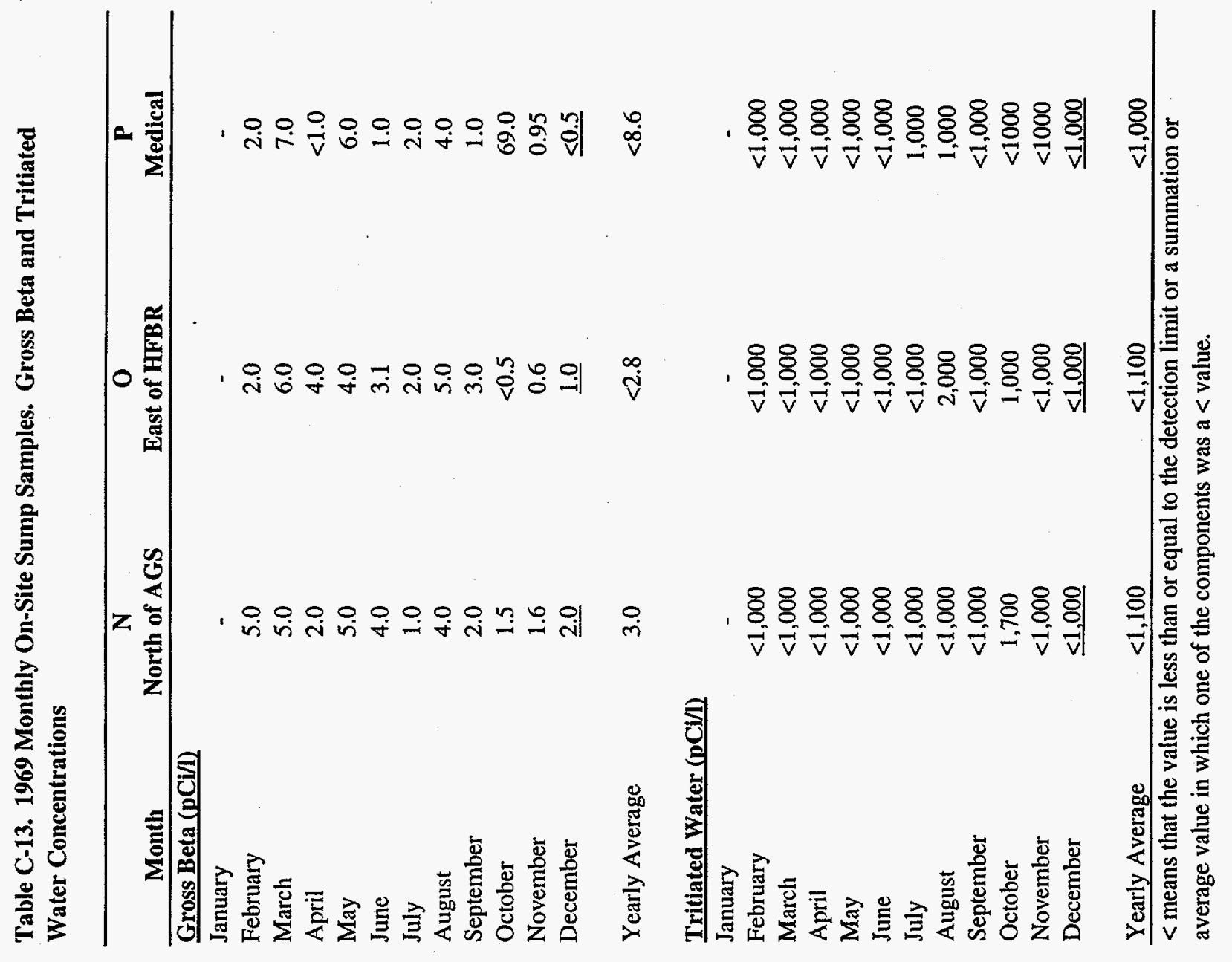


Table C-14. Concentrations in 1969 Milk Samples from Off-site Dairies

\begin{tabular}{|c|c|c|c|c|c|c|c|c|c|}
\hline & \multicolumn{3}{|c|}{ Farm B' $(8 \mathrm{~km} \mathrm{SW})$} & \multicolumn{3}{|c|}{ Farm C $(10 \mathrm{~km} \mathrm{SE})$} & \multicolumn{3}{|c|}{ Farm D (15 km NW) } \\
\hline Month & $\begin{array}{l}{ }^{65} \mathrm{Zn} \\
\mathrm{pCi} / / \\
\end{array}$ & $\begin{array}{c}{ }^{131} \mathrm{I} \\
\mathrm{pCi} / \mathrm{I} \\
\end{array}$ & $\begin{array}{l}{ }^{137} \mathrm{Cs} \\
\mathrm{pCi} / \mathrm{l}\end{array}$ & $\begin{array}{l}{ }^{65} \mathrm{Zn} \\
\mathrm{pCi} / / \\
\end{array}$ & $\begin{array}{c}{ }^{131} \mathrm{I} \\
\mathrm{pCi} / \mathrm{l}\end{array}$ & $\begin{array}{l}{ }^{137} \mathrm{Cs} \\
\mathrm{pCi} / / \\
\end{array}$ & $\begin{array}{r}{ }^{65} \mathrm{Zn} \\
\mathrm{pCi} / / \\
\end{array}$ & $\begin{array}{c}{ }_{131} \mathbf{I} \\
\mathrm{pCi} / \mathbf{l} \\
\end{array}$ & $\begin{array}{r}{ }^{137} \mathrm{Cs} \\
\mathrm{pCi} / / \\
\end{array}$ \\
\hline January & 23.0 & $<1.0$ & $<5.0$ & 53.0 & $<1.0$ & 19 & 23.0 & $<1.0$ & $<5.0$ \\
\hline March & - & - & - & - & - & - & - & - & - \\
\hline April & - & 1.7 & 16 & - & 1.1 & 10 & - & 1.4 & 6.8 \\
\hline May & - & 8.0 & 22 & - & 7.0 & 19 & - & 3.0 & - \\
\hline August & - & - & 9.0 & - & 3.0 & 20 & - & 1.0 & 17 \\
\hline September & - & 1.0 & 18 & - & 1.0 & 10 & - & 1.0 & 14 \\
\hline October & - & 6.1 & 13 & - & - & 5.0 & - & 3.0 & 16 \\
\hline November & - & 4.0 & 16 & - & 8.6 & 10 & - & 6.7 & 23 \\
\hline December & - & - & - & - & - & - & - & - & - \\
\hline
\end{tabular}

$<$ means that the value is less than or equal to the detection limit or a summation or average value

in which one of the components was a $<$ value. 
Table C-15. Concentrations in 1969 Vegetation Sampled from Off-site Farms

\begin{tabular}{|c|c|c|c|c|c|c|c|c|}
\hline & & ${ }^{7} \mathbf{B e}$ & ${ }^{65} \mathrm{Zn}$ & ${ }^{95} \mathrm{Zr}-\mathrm{Nb}$ & ${ }^{131} I$ & ${ }^{137} \mathrm{Cs}$ & ${ }^{140} \mathrm{Ba}-\mathrm{La}$ & ${ }^{144} \mathrm{Ce}$ \\
\hline Location & Month & \multicolumn{7}{|c|}{ pCi/kg (wet) } \\
\hline \multirow{2}{*}{ Farm A (3 km NW). } & July & 4,200 & $<50$ & 1,800 & - & 79 & - & - \\
\hline & October & 7,400 & - & 1,100 & - & 400 & 790 & - \\
\hline \multirow[t]{2}{*}{ Farm B' (8 km SW) } & July & - & - & - & - & - & - & - \\
\hline & October & 930 & 95 & 160 & 18 & 37 & 130 & - \\
\hline \multirow[t]{2}{*}{ Farm C (10 km SE) } & July & 940 & 88 & 520 & - & 91 & - & - \\
\hline & October & 1,800 & - & 340 & 32 & 83 & 170 & - \\
\hline \multirow[t]{2}{*}{ Farm D $(15 \mathrm{~km} \mathrm{NW})$} & July & 2,300 & $<50$ & 720 & - & $<50$ & - & 4,300 \\
\hline & October & 1,100 & - & 230 & 18 & 110 & 190 & - \\
\hline \multirow[t]{2}{*}{ Farm H (6 km NE) } & July & 5,300 & $<50$ & 2,300 & - & 210 & - & 1,500 \\
\hline & October & 4,700 & - & 93 & - & 270 & 520 & - \\
\hline
\end{tabular}

$<$ means that the value is less than or equal to the detection limit or a summation or average value in which one of the components was a $<$ value. 
Table C-16. Concentrations in 1969 Soil Sampled from Off-site Farms

\begin{tabular}{|c|c|c|c|c|c|c|c|c|c|}
\hline & & ${ }^{7} \mathbf{B e}$ & $\overline{{ }^{65} \mathrm{Zn}}$ & ${ }^{95} \mathrm{Zr}-\mathrm{Nb}$ & ${ }^{125} \mathrm{Sb}$ & ${ }^{137} \mathrm{Cs}$ & ${ }^{144} \mathrm{Ce}$ & ${ }^{238} U$ & $\overline{{ }^{232} \mathrm{Th}}$ \\
\hline Location & Month & \multicolumn{8}{|c|}{ pCi/kg (dry) } \\
\hline \multirow[t]{2}{*}{ Farm A $(3 \mathrm{~km} \mathrm{NW})$} & July & $<500$ & $<50$ & 89 & 74 & 1,400 & $<500$ & 360 & 500 \\
\hline & October & - & - & - & - & 1,000 & - & - & - \\
\hline \multirow[t]{2}{*}{ Farm B' $(8 \mathrm{~km} \mathrm{SW})$} & July & $<500$ & $<50$ & 260 & $<50$ & 1,300 & $<500$ & 440 & 1,100 \\
\hline & October & - & - & 240 & - & 1,800 & - & - & - \\
\hline \multirow[t]{2}{*}{ Farm C $(10 \mathrm{~km} \mathrm{SE})$} & July & $<500$ & $<50$ & 130 & $<50$ & 1,100 & $<500$ & 440 & 830 \\
\hline & October & 1,200 & - & 540 & - & 530 & - & - & - \\
\hline \multirow[t]{2}{*}{ Farm D $(15 \mathrm{~km} \mathrm{NW})$} & July & $<500$ & $<50$ & 370 & $<50$ & 1,600 & $<500$ & 1,300 & 1,800 \\
\hline & October & - & - & - & - & 1,300 & - & - & - \\
\hline \multirow[t]{2}{*}{ Farm H (6 km NE) } & July & $<500$ & $<50$ & 160 & $<50$ & 1,700 & $<500$ & 1,300 & 1,500 \\
\hline & October & - & - & - & - & - & - & - & - \\
\hline
\end{tabular}

$<$ means that the value is less than or equal to the detection limit or a summation or average value in which one of the components was a $<$ value. 
APPENDIX D

1970 TABLES 
Table D-1. 1970 Background and Source Radiation Levels at the Laboratory Perimeter (mR/week)

\begin{tabular}{|c|c|c|c|c|c|c|c|c|}
\hline Station: & P-2 & P-4 & P-7 & $\mathbf{P}$ & & S-13 & & 0.6 \\
\hline & $\begin{array}{l}\text { Northwest } \\
\text { Perimeter }\end{array}$ & $\begin{array}{l}\text { Southwest } \\
\text { Perimeter }\end{array}$ & $\begin{array}{l}\text { Southeast } \\
\text { Perimeter }\end{array}$ & $\begin{array}{l}\text { Nort } \\
\text { Perin }\end{array}$ & $\begin{array}{l}\text { ert } \\
\text { er } \\
\text { Ecology }\end{array}$ & On-si & é & Off-site \\
\hline Month & Background & Background & Background & Background & Source & Background & Source & Background \\
\hline January & 1.6 & 1.7 & 1.6 & 1.6 & 1.2 & 1.6 & 0.61 & 1.5 \\
\hline February & 1.8 & 1.7 & 1.7 & 1.6 & 1.3 & 1.6 & 0.59 & 1.6 \\
\hline March & 1.5 & 1.8 & 1.7 & 1.8 & 1.3 & 1.7 & 0.72 & $1.6^{\mathrm{b}}$ \\
\hline April & 1.5 & 1.8 & 1.7 & 2.0 & 1.5 & 1.7 & 0.79 & - \\
\hline May & 1.4 & 1.8 & 1.5 & 2.0 & 1.7 & 1.7 & 0.94 & - \\
\hline June & 1.5 & 1.9 & 1.7 & 1.7 & 1.8 & 1.7 & 1.1 & - \\
\hline July & 1.7 & 1.9 & 1.7 & 1.7 & 1.9 & 1.8 & 1.1 & - \\
\hline August & 2.0 & 1.9 & 1.7 & 1.7 & 1.9 & 1.9 & 1.3 & - \\
\hline September & 2.0 & 1.9 & 1.8 & 1.7 & 1.7 & 1.9 & 1.2 & - \\
\hline October & 2.1 & 2.1 & 1.9 & 1.9 & 1.7 & 2.1 & 1.0 & - \\
\hline November & 2.1 & 2.1 & 1.9 & 1.9 & 1.6 & 2.1 & 0.99 & - \\
\hline December & $\underline{2.0}$ & $\underline{2.1}$ & $\underline{2.0}$ & $\underline{1.9}$ & 1.5 & $\underline{2.0}$ & $\underline{0.87}$ & - \\
\hline Average $\mathrm{mR} /$ week & 1.8 & 1.9 & 1.7 & 1.8 & 1.6 & 1.8 & 0.93 & NA \\
\hline Total $\mathrm{mR} /$ year & 94 & 99 & 88 & 93 & 83 & 94 & 48 & NA \\
\hline
\end{tabular}

${ }^{a}$ At the new northeast perimeter the yearly average would have been $.32 \mathrm{mrem} / \mathrm{wk}$ and $17 \mathrm{mrem} / \mathrm{yr}$ (20\% of 1.6 and 83 ).

${ }^{b}$ Final data. Station discontinued. 
Table D-2. 1970 Monthly Average Gross Beta Concentrations, Air Particulate Filters (pCi/m³)

\begin{tabular}{|c|c|c|c|c|c|c|c|c|c|}
\hline Month & $\begin{array}{c}\text { Gross } \\
\text { Beta }\end{array}$ & ${ }^{7} \mathbf{B e}$ & ${ }^{65} \mathrm{Zn}$ & ${ }^{90} \mathrm{Sr}$ & ${ }^{95} \mathrm{Zr}-\mathrm{Nb}$ & ${ }^{131} \mathbf{I}$ & ${ }^{137} \mathrm{Cs}$ & ${ }^{140} \mathrm{Ba}-\mathrm{La}$ & ${ }^{144} \mathrm{Ce}$ \\
\hline January & 0.098 & 0.17 & 0.002 & - & 0.020 & $<0.001$ & 0.005 & $<0.001$ & 0.032 \\
\hline February & 0.14 & 0.19 & 0.002 & - & 0.060 & $<0.001$ & 0.006 & $<0.001$ & 0.035 \\
\hline March & 0.17 & 0.21 & 0.002 & - & 0.045 & $<0.001$ & 0.005 & $<0.001$ & 0.026 \\
\hline April & 0.24 & 0.30 & 0.004 & 0.003 & 0.092 & $<0.001$ & 0.010 & $<0.001$ & 0.12 \\
\hline May & 0.35 & 0.45 & 0.006 & 0.004 & 0.18 & $<0.001$ & 0.018 & $<0.001$ & 0.091 \\
\hline June & 0.43 & 0.51 & 0.009 & 0.006 & 0.21 & $<0.001$ & 0.035 & $<0.001$ & 0.15 \\
\hline July & 0.33 & 0.67 & 0.012 & 0.006 & 0.28 & $<0.001$ & 0.043 & $<0.001$ & 0.19 \\
\hline August & 0.30 & 0.32 & 0.062 & 0.005 & 0.12 & $<0.001$ & 0.019 & $<0.001$ & 0.12 \\
\hline September & 0.12 & 0.17 & 0.003 & 0.002 & 0.042 & $<0.001$ & 0.009 & $<0.001$ & 0.046 \\
\hline October & 0.10 & 0.15 & 0.002 & - & 0.025 & $<0.001$ & 0.008 & $<0.001$ & 0.036 \\
\hline November & 0.11 & 0.17 & 0.002 & 0.001 & 0.042 & 0.006 & 0.006 & 0.008 & 0.040 \\
\hline December & $\underline{0.11}$ & $\underline{0.15}$ & $\underline{0.002}$ & $\underline{0.001}$ & $\underline{0.11}$ & $\underline{0.022}$ & $\underline{0.006}$ & $<0.001$ & $\underline{0.026}$ \\
\hline Yearly Average & 0.21 & 0.29 & 0.009 & 0.004 & 0.10 & 0.003 & 0.014 & 0.002 & 0.076 \\
\hline
\end{tabular}

$<$ means that the value is less than or equal to the detection limit or a summation or average value in which

one of the components was a $<$ value. 
Table D-3. 1970 Monthly Average Gross Beta Concentrations and Total Gross Beta Activity in Precipitation

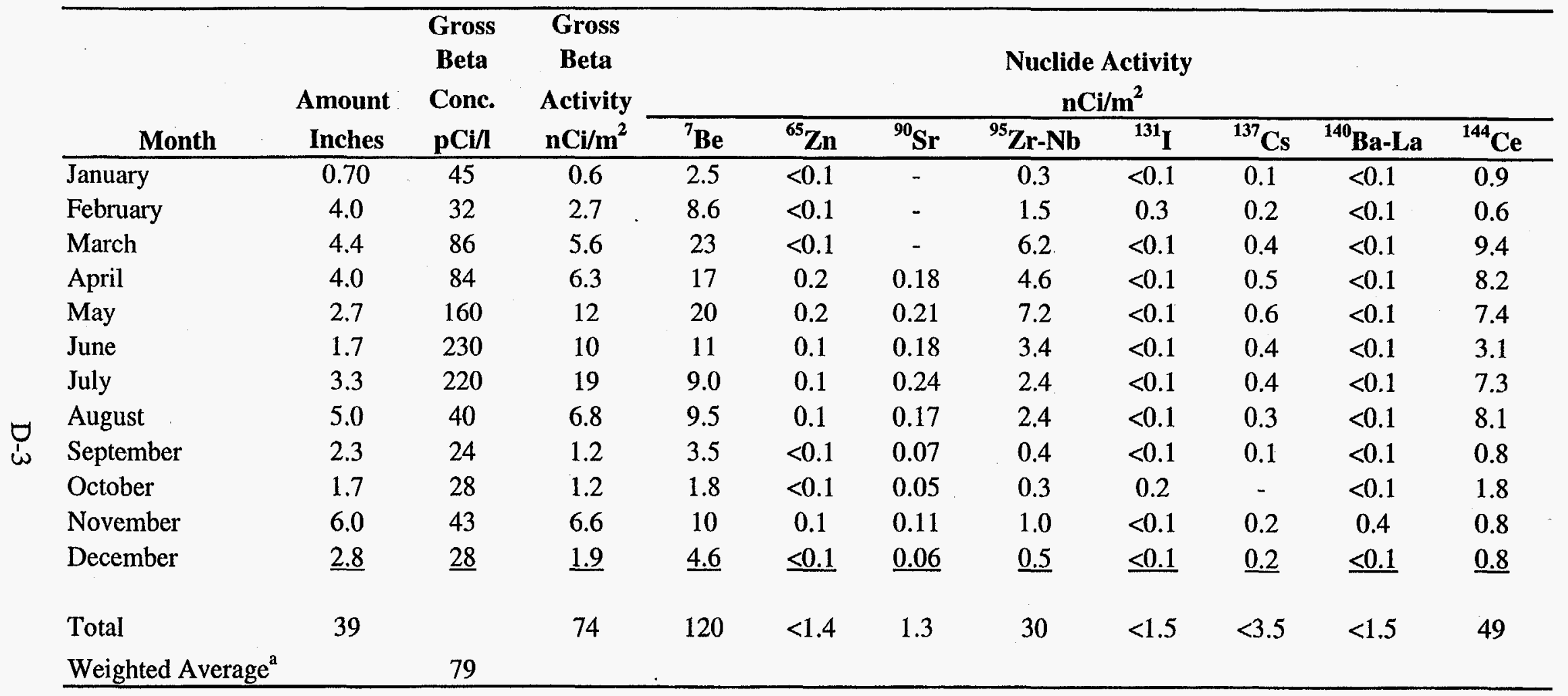

${ }^{\mathrm{a}}$ Weighted by inches of rainfall.

$<$ means that the value is less than or equal to the detection limit or a summation or average value in which one of the components was $\mathrm{a}<$ value. 
Table D-4. 1970 HFBR Stack Emission

\begin{tabular}{|c|c|c|c|c|}
\hline \multirow[b]{2}{*}{ Month } & \multirow[b]{2}{*}{$\begin{array}{l}\text { HFBR } \\
\text { (MWd) }\end{array}$} & \multirow[b]{2}{*}{$\begin{array}{c}\text { Air volume, } \\
\mathbf{m}^{3 \mathrm{a}}\end{array}$} & \multicolumn{2}{|c|}{ Tritiated Water Vapor } \\
\hline & & & $\begin{array}{c}\text { Amount } \\
\mathbf{C i}\end{array}$ & $\begin{array}{l}\text { Conc. } \\
\mathrm{pCi} / \mathrm{m}^{3}\end{array}$ \\
\hline January & 0 & $1.9 \mathrm{E}+07$ & 280 & $1.5 \mathrm{E}+07$ \\
\hline February & 780 & $1.9 \mathrm{E}+07$ & 33 & $1.7 \mathrm{E}+06$ \\
\hline March & 830 & $1.9 \mathrm{E}+07$ & 38 & $2.0 \mathrm{E}+06$ \\
\hline April & 940 & $1.9 \mathrm{E}+07$ & 41 & $2.2 \mathrm{E}+06$ \\
\hline May & 670 & $1.9 \mathrm{E}+07$ & 28 & $1.5 \mathrm{E}+06$ \\
\hline June & 1,000 & $1.9 \mathrm{E}+07$ & 33 & $1.7 \mathrm{E}+06$ \\
\hline July & 570 & $1.9 \mathrm{E}+07$ & 13 & $6.8 \mathrm{E}+05$ \\
\hline August & 880 & $1.9 E+07$ & 38 & $2.0 \mathrm{E}+06$ \\
\hline September & 810 & $1.9 \mathrm{E}+07$ & 49 & $2.6 \mathrm{E}+06$ \\
\hline October & 860 & $1.9 \mathrm{E}+07$ & 63 & $3.3 E+06$ \\
\hline November & 1,000 & $1.9 \mathrm{E}+07$ & 39 & $2.1 \mathrm{E}+06$ \\
\hline December & $\underline{650}$ & $1.9 \mathrm{E}+07$ & $\underline{32}$ & $1.7 \mathrm{E}+06$ \\
\hline Annual total & 8,990 & $2.3 \mathrm{E}+08$ & 690 & \\
\hline Average & & & & $3.0 \mathrm{E}+06$ \\
\hline
\end{tabular}


Table D-5. 1970 Clarifier. Flow, Gross Beta, Tritiated Water, ${ }^{90} \mathrm{Sr}$, and ${ }^{137} \mathrm{Cs}$ Amounts and Concentrations

\begin{tabular}{|c|c|c|c|c|c|c|c|c|c|}
\hline \multirow[b]{2}{*}{ Month } & \multirow[b]{2}{*}{$\begin{array}{l}\text { Flow } \\
10^{9} 1\end{array}$} & \multicolumn{2}{|c|}{ Gross Beta $^{a}$} & \multicolumn{2}{|c|}{ Tritiated Water } & \multicolumn{2}{|c|}{${ }^{90} \mathrm{Sr}$} & \multicolumn{2}{|c|}{${ }^{137} \mathrm{Cs}$} \\
\hline & & $\begin{array}{l}\text { Conc. } \\
\text { pCi// }\end{array}$ & $\begin{array}{c}\text { Amount } \\
\text { mCi }\end{array}$ & $\begin{array}{l}\text { Conc. } \\
\text { pCi/ }\end{array}$ & $\begin{array}{c}\text { Amount } \\
\text { mCi }\end{array}$ & $\begin{array}{l}\text { Conc. } \\
\text { pCi/ }\end{array}$ & $\begin{array}{c}\text { Amount } \\
\text { mCi }\end{array}$ & $\begin{array}{l}\text { Conc. } \\
\text { pCi// }\end{array}$ & $\begin{array}{c}\text { Amount } \\
\text { mCi }\end{array}$ \\
\hline January & 0.099 & 68 & 6.7 & 2,700 & 270 & 1.5 & 0.15 & 60.0 & 5.9 \\
\hline February & 0.10 & 110 & 11.0 & 22,000 & 2,200 & 1.4 & 0.14 & 7.0 & 0.7 \\
\hline March & 0.11 & 43 & 4.7 & 90,000 & 9,900 & 1.5 & 0.17 & 12.0 & 1.3 \\
\hline April & 0.13 & 35 & 4.6 & 17,000 & 2,200 & 4.2 & 0.55 & 10.0 & 1.3 \\
\hline May & 0.15 & 16 & 2.4 & 29,000 & 4,400 & 1.5 & 0.23 & 1.0 & 0.15 \\
\hline June & 0.15 & 20 & 3.0 & 31,000 & 4,700 & 1.2 & 0.18 & 2.0 & 0.30 \\
\hline July & 0.18 & 19 & 3.4 & 18,000 & 3,200 & 1.0 & 0.18 & 8.0 & 1.4 \\
\hline August & 0.19 & 11 & 1.2 & 11,000 & 2,100 & 0.95 & 0.18 & 0.2 & 0.038 \\
\hline September & 0.17 & 7 & 1.2 & 9,500 & 1,600 & 0.64 & 0.11 & 0.9 & 0.15 \\
\hline October & 0.15 & 7 & 1.1 & 19,000 & 2,900 & 0.47 & 0.071 & 1.0 & 0.15 \\
\hline November & 0.17 & 20 & 3.4 & 5,100 & 870 & 0.60 & 0.10 & 0.4 & 0.068 \\
\hline December & $\underline{0.11}$ & $\underline{20}$ & $\underline{2.2}$ & 9,400 & $\underline{1,000}$ & $\underline{1.3}$ & $\underline{0.14}$ & $\underline{5.0}$ & $\underline{0.55}$ \\
\hline Total & 1.7 & & 45 & & 35,000 & & 2.2 & & 12 \\
\hline Weighted Average $^{\mathrm{b}}$ & & 26 & & 21,000 & & 1.3 & & 7.1 & \\
\hline
\end{tabular}

${ }^{a}$ Includes gamma-only emitters; does not include tritiated water.

${ }^{\mathrm{b}}$ Weighted average concentration $=$ total amount $(\mathrm{mCi}) /$ total flow $\left(10^{9} \mathrm{l}\right)$. 
Table D-6. 1970 Chlorinating Plant. Flow, Gross Beta, Tritiated Water, ${ }^{90} \mathrm{Sr}$, and ${ }^{137} \mathrm{Cs}$ Amounts and Concentrations

\begin{tabular}{|c|c|c|c|c|c|c|c|c|c|}
\hline \multirow[b]{2}{*}{ Month } & \multirow[b]{2}{*}{$\begin{array}{l}\text { Flow } \\
10^{9} 1\end{array}$} & \multicolumn{2}{|c|}{ Gross Beta $^{\mathrm{a}}$} & \multicolumn{2}{|c|}{ Tritiated Water } & \multicolumn{2}{|c|}{${ }^{90} \mathrm{Sr}$} & \multicolumn{2}{|c|}{${ }^{137} \mathrm{Cs}$} \\
\hline & & $\begin{array}{l}\text { Conc. } \\
\text { pCi/l }\end{array}$ & $\begin{array}{c}\text { Amount } \\
\text { mCi }\end{array}$ & $\begin{array}{l}\text { Conc. } \\
\text { pCi// }\end{array}$ & $\begin{array}{c}\text { Amount } \\
\text { mCi }\end{array}$ & $\begin{array}{l}\text { Conc. } \\
\text { pCi/l }\end{array}$ & $\begin{array}{c}\text { Amount } \\
\text { mCi }\end{array}$ & $\begin{array}{l}\text { Conc. } \\
\text { pCi/l }\end{array}$ & $\begin{array}{c}\text { Amount } \\
\text { mCi }\end{array}$ \\
\hline January & 0.085 & 14 & 1.2 & 2,800 & 240 & 0.85 & 0.07 & 6.0 & 0.51 \\
\hline February & 0.074 & 15 & 1.1 & 19,000 & 1,400 & 1.1 & 0.08 & 8.0 & 0.59 \\
\hline March & 0.10 & 19 & 1.9 & 85,000 & 8,500 & 1.4 & 0.14 & 11.0 & 1.10 \\
\hline April & 0.094 & 27 & 2.5 & 18,000 & 1,700 & 5.6 & 0.53 & 14.0 & 1.30 \\
\hline May & 0.16 & 19 & 3.0 & 29,000 & 4,600 & 3.8 & 0.61 & 14.0 & 2.20 \\
\hline June & 0.13 & 25 & 3.3 & 32,000 & 4,200 & 2.1 & 0.27 & 15.0 & 2.00 \\
\hline July & 0.16 & 34 & 5.4 & 19,000 & 3,000 & 1.7 & 0.27 & 22.0 & 3.50 \\
\hline August & 0.16 & 15 & 2.4 & 12,000 & 1,900 & 1.3 & 0.21 & 0.9 & 0.14 \\
\hline September & 0.15 & 7.0 & 1.1 & 9,900 & 1,500 & 0.91 & 0.14 & 4.0 & 0.60 \\
\hline October & 0.13 & 8.0 & 1.0 & 18,000 & 2,300 & 0.96 & 0.12 & 5.0 & 0.65 \\
\hline November & 0.12 & 12 & 1.4 & 5,000 & 600 & 0.80 & 0.10 & 4.0 & 0.48 \\
\hline December & $\underline{0.077}$ & $\underline{15}$ & 1.2 & $\underline{9,600}$ & $\underline{740}$ & $\underline{0.90}$ & $\underline{0.07}$ & $\underline{8.0}$ & $\underline{0.62}$ \\
\hline Total & 1.4 & & 26 & & 31,000 & & 2.6 & & 14 \\
\hline Weighted Average $^{b}$ & & 18 & & 21,000 & & 1.9 & & 10 & \\
\hline
\end{tabular}

a Includes gamma-only emitters; does not include tritiated water.

${ }^{\mathrm{b}}$ Weighted average concentration $=$ total amount $(\mathrm{mCi}) /$ total flow $\left(10^{9} \mathrm{l}\right)$. 
Table D-7. 1970 "M" (Former Perimeter). Flow, Gross Beta, Tritiated Water, ${ }^{90} \mathrm{Sr}$, and ${ }^{137} \mathrm{Cs}$ Amounts and Concentrations

\begin{tabular}{|c|c|c|c|c|c|c|c|c|c|}
\hline \multirow[b]{2}{*}{ Month } & \multirow[b]{2}{*}{$\begin{array}{l}\text { Flow } \\
10^{9} 1\end{array}$} & \multicolumn{2}{|c|}{ Gross Beta $^{a}$} & \multicolumn{2}{|c|}{ Tritiated Water } & \multicolumn{2}{|c|}{${ }^{90} \mathrm{Sr}$} & \multicolumn{2}{|c|}{${ }^{137} \mathrm{Cs}$} \\
\hline & & $\begin{array}{l}\text { Conc. } \\
\text { pCi// }\end{array}$ & $\underset{\text { mCi }}{\text { Amount }}$ & $\begin{array}{l}\text { Conc. } \\
\text { pCi/I }\end{array}$ & $\underset{\mathrm{mCi}}{\operatorname{Amount}}$ & $\begin{array}{l}\text { Conc. } \\
\text { pCi/I }\end{array}$ & $\begin{array}{c}\text { Amount } \\
\text { mCi }\end{array}$ & $\begin{array}{l}\text { Conc. } \\
\text { pCi/l }\end{array}$ & $\underset{\text { mCi }}{\text { Amount }}$ \\
\hline January & 0.097 & 14 & 1.4 & 2,700 & 260 & 0.85 & 0.08 & 5.0 & 0.5 \\
\hline February & 0.09 & 14 & 1.3 & 15,000 & 1,400 & 1.10 & 0.10 & 7.0 & 0.63 \\
\hline March & 0.10 & 17 & 1.7 & 73,000 & 7,300 & 1.70 & 0.17 & 11.0 & 1.1 \\
\hline April & 0.16 & 18 & 2.9 & 9,700 & 1,500 & 3.80 & 0.61 & 9.0 & 1.4 \\
\hline June & 0.14 & 23 & 3.2 & 32,000 & 4,500 & 1.60 & 0.22 & 15.0 & 2.1 \\
\hline July & 0.16 & 35 & 5.6 & 20,000 & 3,200 & 1.40 & 0.22 & 15.0 & 2.4 \\
\hline August & 0.16 & 17 & 2.7 & 12,000 & 1,900 & 1.40 & 0.22 & 2.0 & 0.32 \\
\hline September & 0.15 & 8 & 1.2 & 9,700 & 1,500 & 1.20 & 0.28 & 6.0 & 0.90 \\
\hline October & 0.13 & 8 & 1.0 & 20,000 & 2,600 & 0.97 & 0.13 & 4.0 & 0.52 \\
\hline November & 0.12 & 12 & 1.4 & 5,400 & 650 & 0.90 & 0.11 & 3.0 & 0.36 \\
\hline December & $\underline{0.087}$ & $\underline{14}$ & $\underline{1.2}$ & $\underline{9,000}$ & $\underline{780}$ & $\underline{0.90}$ & $\underline{0.08}$ & $\underline{7.0}$ & $\underline{0.61}$ \\
\hline Total & 1.6 & & 27 & & 31,000 & & 3.0 & & 13 \\
\hline Weighted Average $^{\mathrm{b}}$ & & 17 & & 19,000 & & 1.9 & & 8.1 & \\
\hline
\end{tabular}

${ }^{a}$ Includes gamma-only emitters; does not include tritiated water.

${ }^{\mathrm{b}}$ Weighted average concentration $=$ total amount $(\mathrm{mCi}) /$ total flow $\left(10^{9} \mathrm{l}\right)$. 
Table D-8. 1970 " $Q$ " (Current Perimeter). ${ }^{\text {a } F l o w, ~ G r o s s ~ B e t a, ~ T r i t i a t e d ~ W a t e r, ~}{ }^{90} \mathrm{Sr}$ and ${ }^{137} \mathrm{Cs}$ Amounts and Concentrations

\begin{tabular}{|c|c|c|c|c|c|c|c|c|c|}
\hline \multirow[b]{2}{*}{ Month } & \multirow[b]{2}{*}{$\begin{array}{c}\text { Flow } \\
10^{9} 1\end{array}$} & \multicolumn{2}{|c|}{ Gross Beta $^{a}$} & \multicolumn{2}{|c|}{ Tritiated Water } & \multicolumn{2}{|c|}{${ }^{90} \mathrm{Sr}$} & \multicolumn{2}{|c|}{${ }^{137} \mathrm{Cs}$} \\
\hline & & $\begin{array}{l}\text { Conc. } \\
\text { pCi/l }\end{array}$ & $\begin{array}{c}\text { Amount } \\
\text { mCi }\end{array}$ & $\begin{array}{l}\text { Conc. } \\
\mathrm{pCi} / \mathrm{I}\end{array}$ & $\begin{array}{c}\text { Amount } \\
\text { mCi }\end{array}$ & $\begin{array}{l}\text { Conc. } \\
\text { pCi// }\end{array}$ & $\begin{array}{c}\text { Amount } \\
\text { mCi }\end{array}$ & $\begin{array}{l}\text { Conc. } \\
\text { pCi/l }\end{array}$ & $\begin{array}{c}\text { Amount } \\
\text { mCi }\end{array}$ \\
\hline January & 0.11 & 12 & 1.3 & 3,200 & 350 & 0.80 & 0.09 & 5.0 & 0.55 \\
\hline February & 0.10 & 11 & 1.1 & 12,000 & 1,200 & 1.3 & 0.13 & 6.0 & 0.60 \\
\hline March & 0.077 & 15 & 1.2 & 75,000 & 5,800 & 1.6 & 0.12 & 9.0 & 0.69 \\
\hline April & 0.17 & 13 & 2.2 & 11,000 & 1,900 & 2.6 & 0.44 & 7.0 & 1.20 \\
\hline May & 0.14 & 16 & 2.2 & 22,000 & 3,100 & 2.4 & 0.34 & 11 & 1.50 \\
\hline June & 0.14 & 25 & 3.5 & 30,000 & 4,200 & 1.2 & 0.17 & 13 & 1.80 \\
\hline July & 0.12 & 43 & 5.2 & 19,000 & 2,300 & 1.1 & 0.13 & 16 & 1.90 \\
\hline August & 0.10 & 18 & 1.8 & 14,000 & 1,400 & 1.6 & 0.16 & 9.0 & 0.90 \\
\hline September & 0.06 & 10 & 0.6 & 8,400 & 500 & 1.1 & 0.07 & 7.0 & 0.42 \\
\hline October & 0.33 & 8.0 & 2.6 & 18,000 & 5,900 & 1.6 & 0.53 & 6.0 & 2.00 \\
\hline November & 0.035 & 14 & 0.5 & 3,800 & 130 & 1.2 & 0.04 & 5.0 & 0.18 \\
\hline December & $\underline{0.048}$ & $\underline{10}$ & $\underline{0.5}$ & $\underline{6,600}$ & $\underline{320}$ & $\underline{0.7}$ & $\underline{0.03}$ & $\underline{8.0}$ & $\underline{0.38}$ \\
\hline Total & 1.4 & & 23 & & 27,000 & & 2.3 & & 13 \\
\hline Weighted Average ${ }^{b}$ & & 16 & & 19,000 & & 1.6 & & 8.6 & \\
\hline
\end{tabular}

ancludes gamma-only emitters; does not include tritiated water.

${ }^{\mathrm{b}}$ Weighted average concentration $=$ total amount $(\mathrm{mCi}) /$ total flow $\left(10^{9} \mathrm{l}\right)$. 
Table D-9. 1970 Monthly Downstream and Control Location Water Grab Samples. Gross Beta and Tritiated Water

\begin{tabular}{|c|c|c|c|c|c|c|c|c|c|c|c|c|c|}
\hline \multirow[b]{2}{*}{ Month } & \multicolumn{8}{|c|}{ Downstream Locations } & \multicolumn{5}{|c|}{ Control Locations } \\
\hline & $\mathbf{A}$ & B & $\mathrm{C}$ & D & $\mathbf{K}$ & $\mathbf{L}$ & $\mathbf{M}^{\mathrm{a}}$ & $Q^{a}$ & $\mathbf{E}$ & $\mathbf{F}$ & $\mathbf{H}$ & $I$ & $\mathbf{J}$ \\
\hline \multicolumn{14}{|c|}{ Gross Beta (pCi/l) } \\
\hline January & 5.0 & 3.0 & 4.0 & 3.0 & 12 & 12 & 15 & 13 & 4.0 & 31 & 1.0 & 9.0 & 4.0 \\
\hline February & 16 & 8.0 & 7.0 & 7.0 & 24 & 6.0 & 17 & 14 & 6.0 & 6.0 & 5.0 & 28 & 4.0 \\
\hline March & 7.0 & 5.0 & 5.0 & 4.0 & 24 & 18 & 48 & 20 & 6.0 & 3.0 & 3.0 & 6.0 & 5.0 \\
\hline April & 10 & 8.0 & 5.0 & 5.0 & 32 & 25 & 19 & 13 & 5.0 & 7.0 & 4.0 & 9.0 & 6.0 \\
\hline May & 8.0 & 7.0 & 10 & 17 & 25 & 21 & 20 & 14 & 5.0 & 7.0 & 4.0 & 9.0 & 6.0 \\
\hline June & 10 & 7.0 & 7.0 & 4.0 & 17 & 18 & 15 & 25 & $<1.0$ & 2.0 & $<1.0$ & 7.0 & 4.0 \\
\hline July & 10 & 21 & 7.0 & 8.0 & 53 & 29 & 35 & 35 & 12 & 18 & 10 & 21 & 25 \\
\hline August & 8.0 & 5.0 & 4.0 & 8.0 & 13 & 15 & 22 & 11 & 6.0 & 5.0 & 1.0 & 8.0 & 2.0 \\
\hline September & 8.0 & 3.0 & 4.0 & 3.0 & 7.0 & 10 & 7.0 & 6.0 & 6.0 & 4.0 & 1.0 & 6.0 & 10 \\
\hline October & 5.0 & 3.0 & 4.0 & 4.0 & 9.0 & 9.0 & 4.0 & 7.0 & 8.0 & 8.0 & 2.0 & 5.0 & 4.0 \\
\hline November & 6.0 & 5.0 & 6.0 & 5.0 & 10 & 9.0 & 5.0 & 19 & 7.0 & 5.0 & 3.0 & 5.0 & 4.0 \\
\hline December & $\underline{9.0}$ & $\underline{4.0}$ & $\underline{5.0}$ & $\underline{7.0}$ & $\underline{13}$ & $\underline{12}$ & $\underline{17}$ & $\underline{7.0}$ & $\underline{28}$ & $\underline{6.0}$ & $\underline{5.0}$ & $\underline{5.0}$ & $\underline{7.0}$ \\
\hline Yearly Average & 8.5 & 6.6 & 5.7 & 6.3 & 20 & 15 & 19 & 15 & $<7.8$ & 8.5 & $<3.3$ & 10 & 6.8 \\
\hline \multicolumn{14}{|c|}{ Tritiated Water (pCi/l) } \\
\hline January & $<1,000$ & $<1,000$ & $<1,000$ & 1,000 & $<1,000$ & 1,000 & 1,000 & 1,000 & 1,000 & $<1,000$ & $<1,000$ & $<1,000$ & $<1,000$ \\
\hline February & 8,000 & 6,000 & 2,000 & 2,000 & 7,000 & 7,000 & 110,000 & 50,000 & $<1,000$ & $<1,000$ & $<1,000$ & 1,000 & $<1,000$ \\
\hline March & 7,000 & 6,000 & 7,000 & 6,000 & 88,000 & 87,000 & 83,000 & 78,000 & 1,000 & $<1,000$ & $<1,000$ & $<1,000$ & $<1,000$ \\
\hline April & 16,000 & 2,000 & 2,000 & 2,000 & 26,000 & 20,000 & 13,000 & 22,000 & $<1,000$ & $<1,000$ & $<1,000$ & 1,000 & $<1,000$ \\
\hline May & 3,000 & 2,000 & 3,000 & 2,000 & 10,000 & 5,000 & 5,000 & 8,000 & $<1,000$ & $<1,000$ & $<1,000$ & 1,000 & $<1,000$ \\
\hline June & 10,000 & 4,000 & 3,000 & 2,000 & 10,000 & 8,000 & 22,000 & 17,000 & $<1,000$ & 1,000 & $<1,000$ & $<1,000$ & $<1,000$ \\
\hline July & 2,000 & 1,000 & 2,000 & 3,000 & 8,000 & 8,000 & 7,000 & 9,000 & 2,000 & $<1,000$ & $<1,000$ & $<1,000$ & 2,000 \\
\hline August & 4,000 & 3,000 & 2,000 & 2,000 & 7,000 & 8,000 & 2,000 & 4,000 & $<1,000$ & $<1,000$ & $<1,000$ & $<1,000$ & $<1,000$ \\
\hline September & $<1,000$ & $<1,000$ & $<1,000$ & $<1,000$ & 3,000 & 3,000 & 5,000 & 5,000 & $<1,000$ & $<1,000$ & $<1,000$ & $<1,000$ & $<1,000$ \\
\hline October & $<1,000$ & $<1,000$ & $<1,000$ & $<1,000$ & 3,000 & 3,000 & 5,000 & 8,000 & $<1,000$ & $<1,000$ & $<1,000$ & $<1,000$ & $<1,000$ \\
\hline November & 1,000 & $<1,000$ & $<1,000$ & $<1,000$ & 9,000 & 8,000 & 16,000 & 4,000 & $<1,000$ & $<1,000$ & $<1,000$ & $<1,000$ & $<1,000$ \\
\hline December & $\leq 1,000$ & $\leq 1,000$ & $\leq 1,000$ & $\leq 1,000$ & $\underline{18,000}$ & $\underline{17,000}$ & $\underline{13,000}$ & $\underline{10,000}$ & $\leq 1,000$ & $\leq 1,000$ & $\leq 1,000$ & $\leq 1,000$ & $\leq 1,000$ \\
\hline Yearly Average & $<4,600$ & $<2,500$ & $<2,200$ & $<2,000$ & $<16,000$ & 15,000 & $<24,000$ & 18,000 & $<1,100$ & $<1,000$ & $<1,000$ & $<1,000$ & $<1,100$ \\
\hline
\end{tabular}

${ }^{a}$ Continuous sample.

$<$ means that the value is less than or equal to the detection limit or a summation or average value in which one of the components was a $<$ value. 
Table D-10. 1970 Bottom Sediment Sample Concentrations

\begin{tabular}{cccc}
\hline Month & $\begin{array}{c}\text { Peconic } \\
\text { Location }\end{array}$ & $\begin{array}{c}{ }^{60} \mathrm{Co} \\
\mathbf{p C i} / \mathbf{g} \\
\text { (dry) }\end{array}$ & $\begin{array}{c}{ }^{137} \mathrm{Cs} \\
\mathbf{p C i} / \mathbf{g} \\
\text { (dry) }\end{array}$ \\
\hline August & L & 23 & 8 \\
\hline
\end{tabular}




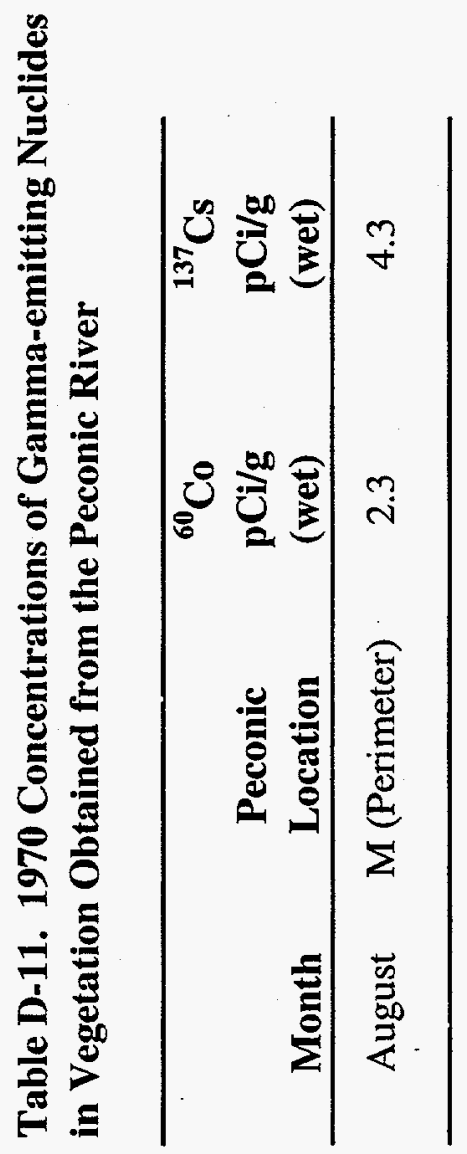

D-11 
Table D-12. 1970 Gross Beta and Tritiated Water Concentrations in Potable and Cooling Water Supply Wells

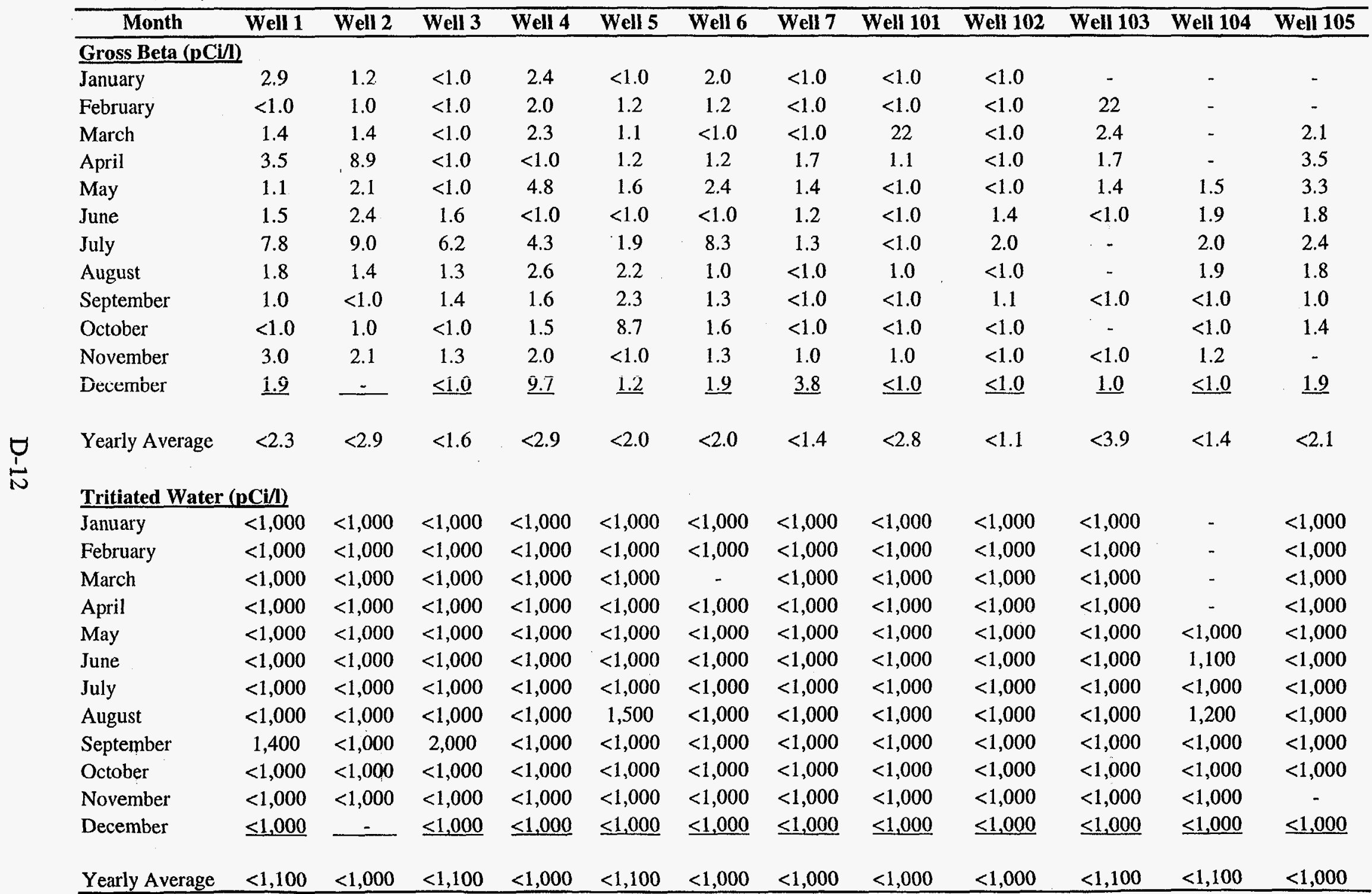

$<$ means that the value is less than or equal to the detection limit or a summation or average value in which one of the components was a $<$ value. 
Table D-13. 1970 Monthly On-Site Sump Samples.

Gross Beta and Tritiated Water Concentrations

\begin{tabular}{|c|c|c|c|}
\hline Month & $\begin{array}{c}\mathrm{N} \\
\text { North of AGS }\end{array}$ & $\begin{array}{c}0 \\
\text { East of HFBR }\end{array}$ & $\begin{array}{c}\mathbf{P} \\
\text { Medical }\end{array}$ \\
\hline \multicolumn{4}{|c|}{ Gross Beta (pCi/l) } \\
\hline January & 3.0 & 1.0 & 2.0 \\
\hline February & 2.0 & 1.0 & $<1.0$ \\
\hline March & 3.0 & 8.0 & 2.0 \\
\hline April & 6.0 & 4.0 & 6.0 \\
\hline May & 6.0 & 4.0 & 6.0 \\
\hline June & 2.0 & 14.0 & 1.0 \\
\hline July & $<1.0$ & 6.0 & 8.0 \\
\hline August & 2.0 & 4.0 & 6.0 \\
\hline September & 4.0 & 7.0 & 2.0 \\
\hline October & 4.0 & 3.0 & 2.0 \\
\hline November & 2.0 & 1.0 & 2.0 \\
\hline December & $\underline{4.0}$ & $\underline{3.0}$ & $\underline{65.0}$ \\
\hline Yearly Average & $<3.3$ & $<4.7$ & $<8.6$ \\
\hline \multicolumn{4}{|c|}{ Tritiated Water (pCi//) } \\
\hline January & $<1,000$ & $<1,000$ & $<1,000$ \\
\hline February & $<1,000$ & $<1,000$ & $<1,000$ \\
\hline March & 1000 & $<1,000$ & $<1,000$ \\
\hline April & $<1,000$ & $<1,000$ & $<1,000$ \\
\hline May & $<1,000$ & $<1,000$ & $<1,000$ \\
\hline June & $<1,000$ & $<1,000$ & $<1,000$ \\
\hline July & $<1,000$ & $<1,000$ & 1000 \\
\hline August & $<1,000$ & 1000 & $<1,000$ \\
\hline September & $<1,000$ & 2000 & $<1,000$ \\
\hline October & $<1,000$ & $<1,000$ & $<1,000$ \\
\hline November & $<1,000$ & $<1,000$ & $<1,000$ \\
\hline December & $\leq 1,000$ & $\leq 1,000$ & $\leq 1,000$ \\
\hline Yearly Average & $<1,000$ & $<1,100$ & $<1,000$ \\
\hline
\end{tabular}


Table D-14. Concentrations in 1970 Milk Samples from Off-site Dairies

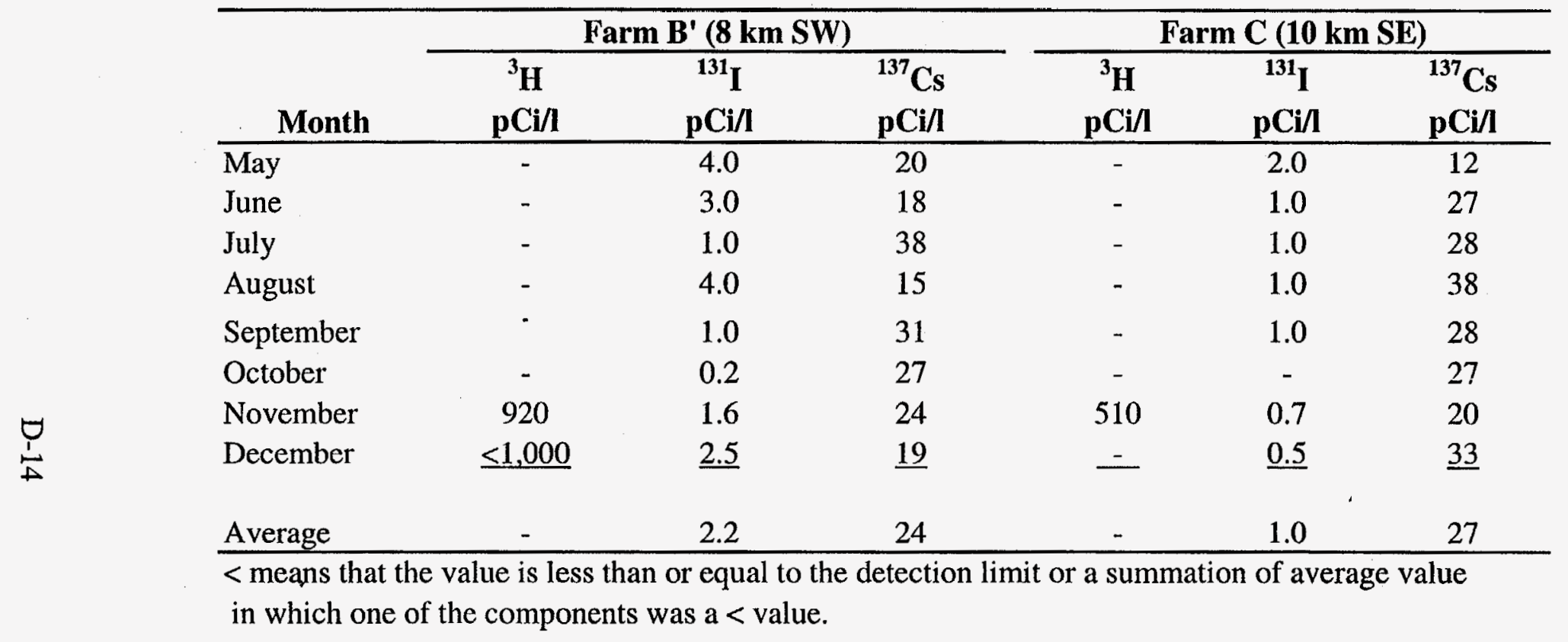


Table D-15. Concentrations in 1970 Vegetation Sampled from Off-site Farms

\begin{tabular}{|c|c|c|c|c|c|c|c|c|}
\hline & & ${ }^{7} \mathbf{B e}$ & ${ }^{65} \mathrm{Zn}$ & ${ }^{95} \mathrm{Zr}-\mathrm{Nb}$ & ${ }^{137} \mathrm{Cs}$ & ${ }^{144} \mathrm{Ce}$ & ${ }^{238} U$ & ${ }^{232} \mathrm{Th}$ \\
\hline Location & Month & \multicolumn{7}{|c|}{ pCi/kg (wet) } \\
\hline \multirow{2}{*}{$\overline{\text { Farm A }(3 \mathrm{~km} \mathrm{NW})}$} & July & 4,300 & 140 & 2,100 & 370 & 2,800 & $<500$ & $<500$ \\
\hline & October & 1,800 & $<100$ & 330 & 260 & 910 & - & - \\
\hline \multirow[t]{2}{*}{ Farm B' $(8 \mathrm{~km} \mathrm{SW})$} & July & 3,700 & 170 & 1,700 & 210 & 1,900 & $<500$ & $<500$ \\
\hline & October & 840 & $<100$ & 200 & 130 & 520 & - & - \\
\hline \multirow[t]{2}{*}{ Farm C (10 km SE) } & July & 2,000 & 100 & 1,100 & 220 & 1,400 & $<500$ & $<500$ \\
\hline & October & 1,400 & $<100$ & 280 & 220 & 350 & - & - \\
\hline \multirow[t]{2}{*}{ Farm D $(15 \mathrm{~km} \mathrm{NW})$} & July & 2,000 & 100 & 900 & 150 & 1,500 & $<500$ & $<500$ \\
\hline & October & 550 & $<100$ & 120 & 40 & 70 & - & - \\
\hline \multirow[t]{2}{*}{ Farm H $(6 \mathrm{~km} \mathrm{NE})$} & July & 3,500 & 80 & 1,800 & 630 & 2,200 & $<500$ & $<500$ \\
\hline & October & 5,300 & $<100$ & 1,300 & 460 & 350 & - & - \\
\hline
\end{tabular}

$<$ means that the value is less than or equal to the detection limit or a summation or average value in which on of the components was a $<$ value. 
Table D-16. Concentrations in 1970 Soil Sampled from Off-site Farms

\begin{tabular}{|c|c|c|c|c|c|c|c|c|}
\hline & & ${ }^{7} \mathrm{Be}$ & ${ }^{65} \mathrm{Zn}$ & ${ }^{95} \mathrm{Zr}-\mathrm{Nb}$ & ${ }^{137} \mathrm{Cs}$ & ${ }^{144} \mathrm{Ce}$ & ${ }^{238} \mathrm{U}$ & ${ }^{232} \mathrm{Th}$ \\
\hline Location & Month & \multicolumn{7}{|c|}{ pCi/kg (dry) } \\
\hline \multirow[t]{2}{*}{ Farm A $(3 \mathrm{~km} \mathrm{NW})$} & July & $<500$ & $<250$ & 220 & 1,900 & $<500$ & 1,000 & 1,600 \\
\hline & October & $<500$ & $<250$ & 150 & 1,800 & $<500$ & 420 & 770 \\
\hline \multirow[t]{2}{*}{ Farm B' $(8 \mathrm{~km} \mathrm{SW})$} & July & $<500$ & $<250$ & 180 & 1,200 & $<500$ & 860 & 1,300 \\
\hline & October & $<500$ & $<250$ & 170 & 1,800 & $<500$ & 500 & 710 \\
\hline \multirow[t]{2}{*}{ Farm C (10 km SE) } & July & $<500$ & $<250$ & 330 & 880 & $<500$ & 770 & 880 \\
\hline & October & $<500$ & $<250$ & 290 & 1,900 & $<500$ & 660 & 1,000 \\
\hline \multirow[t]{2}{*}{ Farm D $(15 \mathrm{~km} \mathrm{NW})$} & July & $<500$ & $<250$ & 290 & 1,300 & $<500$ & 640 & 1,000 \\
\hline & October & $<500$ & $<250$ & 300 & 1,200 & $<500$ & 1,200 & 1,200 \\
\hline \multirow[t]{2}{*}{ Farm H (6 km NE) } & July & $<500$ & $<250$ & 270 & 520 & $<500$ & 520 & 850 \\
\hline & October & $<500$ & $<250$ & 160 & 210 & $<500$ & 510 & 650 \\
\hline
\end{tabular}

